OECDpublishing

\title{
PRUDENT DEBT TARGETS AND FISCAL FRAMEWORKS
}

OECD ECONOMIC POLICY PAPER July 2015 No. 15 


\section{Prudent Debt Targets and Fiscal Frameworks}

This paper has been prepared by:

Falilou Fall

Debbie Bloch

Jean-Marc Fournier

Peter Hoeller

Authorised for publication by Catherine Mann

Chief Economist and G20 Finance Deputy

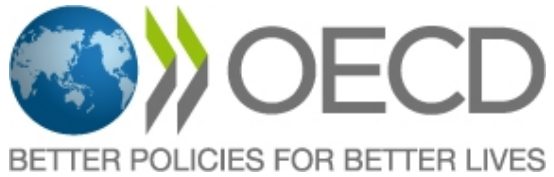


The OECD Economic Policy Paper Series is published on the responsibility of the Secretary-General of the OECD. The opinions expressed and arguments employed herein do not necessarily reflect the official views of the Organisation or of the governments of its member countries.

An earlier version of this paper was discussed at the Working Party No. 1 of the Economic Policy Committee. The authors are indebted to Sebastian Barnes, Hansjoerg Bloechliger, Hans Blommestein, Ronald Downes, Catherine Mann, Christian Kastrop, Jean-Luc Schneider, Arent Skjaeveland, Lisa von Trapp, David Turner and Peter van de Ven for their comments. The authors thank Mabelin Villareal-Fuentes for her important statistical contribution and Celia Rutkoski for excellent editorial assistance.

More detailed information is contained in the following papers:

Bloch, D. and F. Fall (2015), "Government Debt Indicators: Understanding the Data", OECD Economics Department Working Papers, No. 1228, OECD Publishing.

Fournier, J-M. and F. Fall (2015), "Limits to Government Debt Sustainability", OECD Economics Department Working Papers, No. 1229, OECD Publishing.

Fall, F. and J-M. Fournier (2015), "Macroeconomic Uncertainties, Prudent Debt Targets and Fiscal Rules", OECD Economics Department Working Papers, No. 1230, OECD Publishing.

Series: OECD Economic Policy Papers ISSN 2226583X

The statistical data for Israel are supplied by and under the responsibility of the relevant Israeli authorities. The use of such data by the OECD is without prejudice to the status of the Golan Heights, East Jerusalem and Israeli settlements in the West Bank under the terms of international law.

\section{(C) OECD 2015}

You can copy, download or print OECD content for your own use, and you can include excerpts from OECD publications, databases and multimedia products in your own documents, presentations, blogs, websites and teaching materials, provided that suitable acknowledgment of OECD as source and copyright owner is given. All requests for public or commercial use and translation rights should be submitted to rights@oecd.org. Requests for permission to photocopy portions of this material for public or commercial use shall be addressed directly to the Copyright Clearance Center (CCC) at info@copyright.com or the Centre français d'exploitation du droit de copie (CFC) at contact@cfcopies.com. 


\section{TABLE OF CONTENTS}

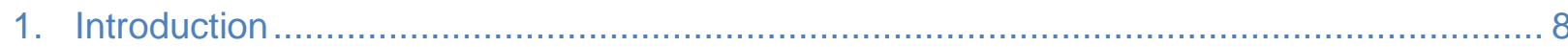

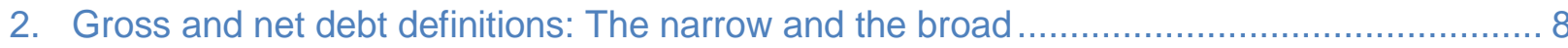

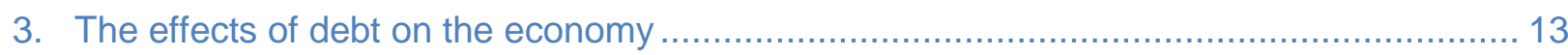

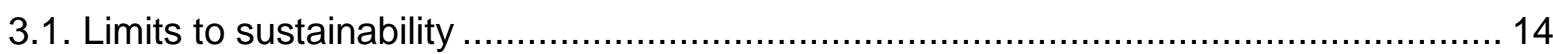

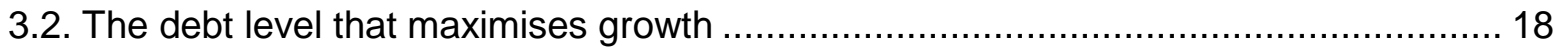

3.3. The effectiveness of fiscal policy in stabilising the economy.................................. 19

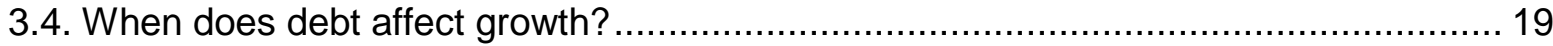

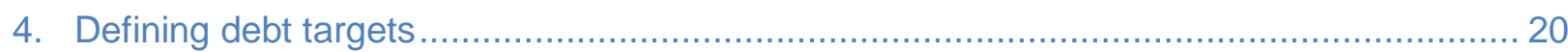

4.1. Finding a debt threshold: Cross-country evidence ............................................. 20

4.2. Debt and the vulnerabilities of countries to specific factors and risks ....................... 24

4.3. Defining a prudent debt target as conveyed by stochastic simulations .................... 26

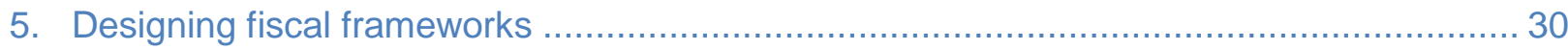

5.1. Justifications, objectives and composition of the fiscal framework ......................... 30

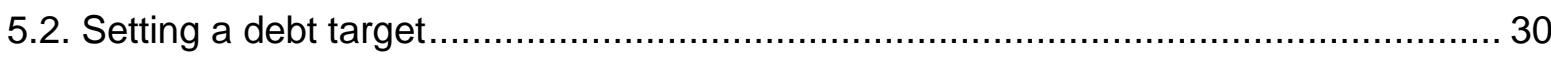

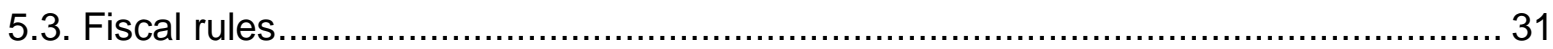

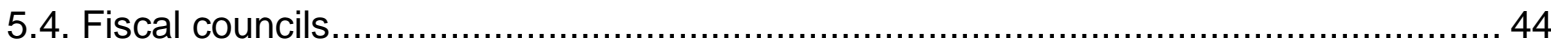

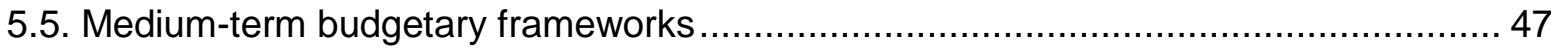

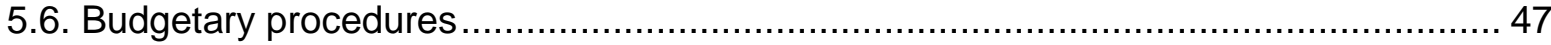

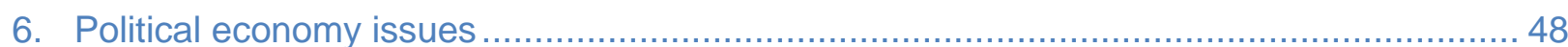

6.1. The credibility of the consolidation path matters for avoiding fiscal fatigue ............... 48

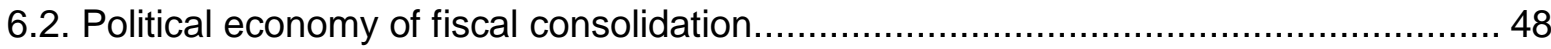

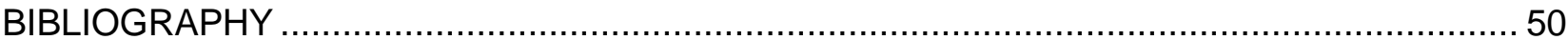

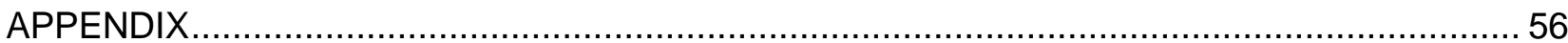




\section{Tables}

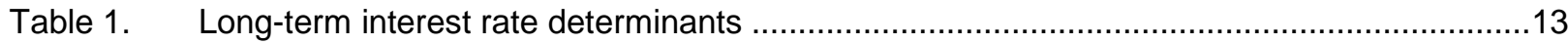

Table 2. Estimations of growth maximising long-run debt-to-GDP ratio.....................................19

Table 3. Fiscal performance and risk indicators for emerging and lower income economies ............23

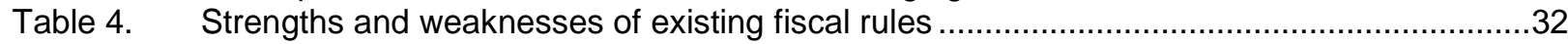

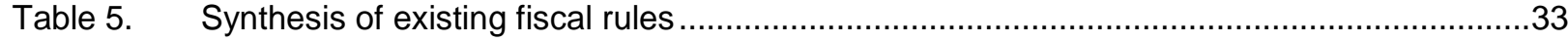

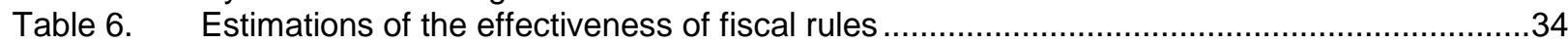

Table 7. Synthesis of the effects of rules with respect to fiscal discipline and stabilisation ................37

Table 8. $\quad$ Simulation results: Grouping of countries and fiscal rules.......................................44

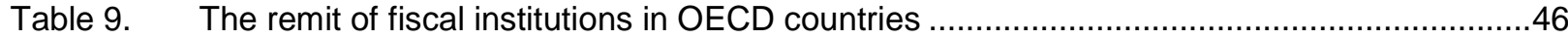

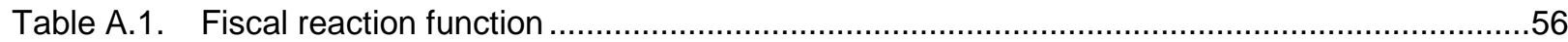

\section{Figures}

Figure 1. The Standardised National Accounts framework for general government debt ...................

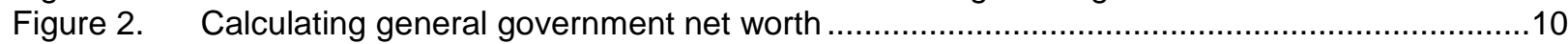

Figure 3. Beyond gross financial liabilities: Accounting for contingent and implicit liabilities ..............11

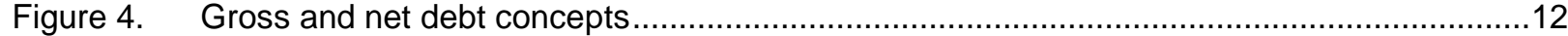

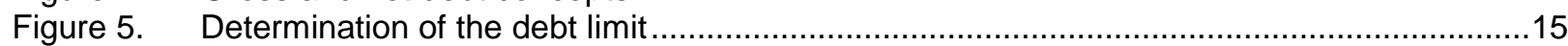

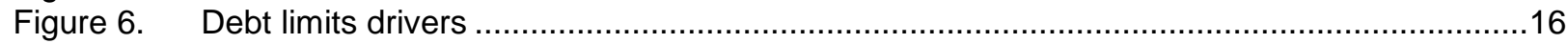

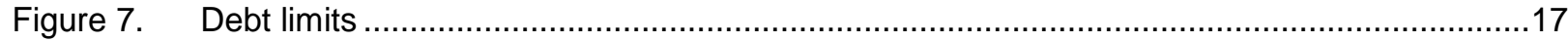

Figure 8. General government gross debt and its external component.....................................25

Figure 9. General government debt by currency denomination in selected OECD countries .............26

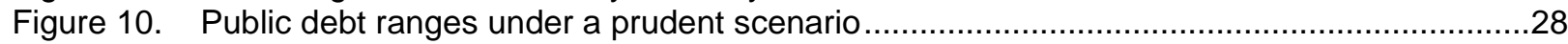

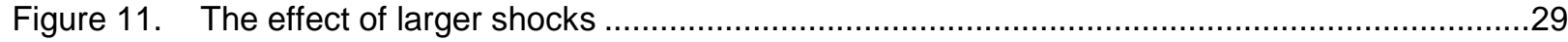

Figure 12. The trade-off between counter-cyclicality and hitting the debt target ...............................35

Figure 13. The pre-crisis overestimation of structural balances ...................................................36

Figure 14. Illustration of a budget balance rule combined with a spending rule: The US example........37

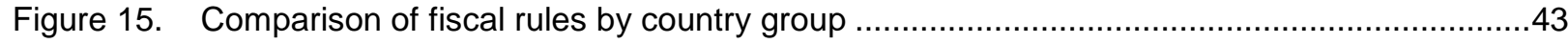

\section{Boxes}

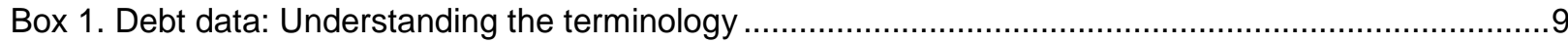

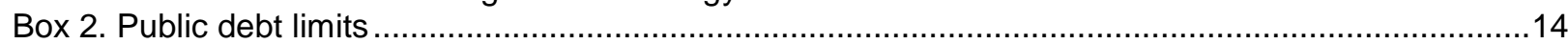

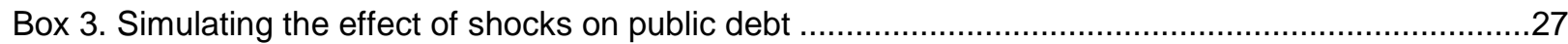

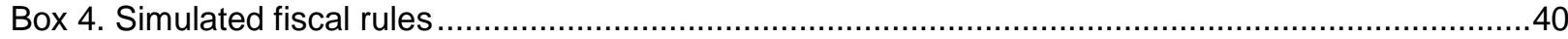




\section{Abstract/Résumé \\ Prudent debt targets and fiscal frameworks}

The sharp rise in debt experienced by most OECD countries raises questions about debt indicators and the prudent government debt level countries should target. It also raises questions about the fiscal frameworks needed to reach the prudent debt level and to accommodate cyclical fluctuations along the convergence path towards a prudent debt target. The objective of this paper is to define long-run prudent debt targets for OECD countries and country-specific fiscal rules. The paper presents a comprehensive analysis of government liabilities and assets and formulates recommendations for debt indicators. It also reviews the different linkages between government debt and the economic activity. The lessons from these analyses are combined with an assessment of the uncertainties surrounding the development of macroeconomic variables to define a prudent debt target. Different fiscal rules are compared with regard their impact on fiscal discipline and the risk of recession for country-specific fiscal rules recommendations.

JEL classification codes: E27; E61; E62; H62; H68

Keywords: Macroeconomic uncertainties, debt, fiscal policy, fiscal rules

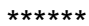

\section{Cibles de dette prudentes et cadres budgétaires}

La montée rapide de l'endettement public dans la plupart des pays de l'OCDE soulève des questions sur le niveau prudent de dette que les pays doivent cibler. II soulève également des questions sur les cadres budgétaires nécessaires pour les atteindre et qui fournissent une marge de manœuvre suffisante pour faire face à des chocs négatifs. Ce document examine les dettes publiques explicites et implicites, ainsi que les actifs qui sont utiles dans l'évaluation des risques budgétaires et la viabilité budgétaire à long terme. Il souligne également les liens positifs et négatifs entre la dette publique et l'activité économique. Les leçons tirées de ces analyses sont combinées avec une évaluation des incertitudes macroéconomiques pour définir une cible prudente de dette. Différentes règles budgétaires sont comparées à l'égard de leur impact sur la discipline budgétaire et le risque de récession, conduisant à des recommandations pour les règles budgétaires qui tiennent compte des spécificités de chaque pays.

Classification JEL : E27 ; E61 ; E62 ; H62 ; H68

Mots-clés : incertitudes macroéconomiques, dette, politique budgétaire, règles budgétaires 


\section{Prudent Debt Targets and Fiscal Frameworks}

\section{Executive summary}

During the recent crisis, government debt has increased sharply in most OECD countries, raising questions about what government debt level countries should target and how fiscal frameworks should be designed to bring debt down to a prudent level.

Debt targets can serve as a fiscal policy anchor to ensure the sustainability of fiscal policy and that there is sufficient policy room to cope with adverse shocks. Prudent debt targets provide the commitment tool that reassures markets and thereby diminishes risk premia not only for government debt, but also lowers the cost of capital for the whole economy.

This policy paper starts by analysing different debt concepts, which are key for analysing fiscal risks and sustainability. Government gross debt serves to monitor contractual liabilities and should include explicit future liabilities such as civil servant pension liabilities. Gross debt should be tracked separately from government assets, as sharp swings in asset prices can mask underlying debt developments. Net debt, the difference between government gross debt and assets, is relevant for solvency analysis, in particular when governments hold a sizeable amount of liquid assets. Implicit and other off-balance sheet liabilities should also be estimated and monitored to assess fiscal risks.

To define a prudent debt target, it is necessary to establish a threshold beyond which debt has adverse effects on economic activity or debt developments become unsustainable. Debt sustainability largely depends on economic growth, the interest rate and the capacity of governments to run primary balances that ensure that the government meets its liabilities. Debt default limits are currently not binding in most countries thanks to very low interest rates. But such limits are state dependent. At high debt levels, countries can lose market confidence and see their borrowing rates increase steeply. Countries should thus endeavour to steer clear of their default limit. The currently high default limits cannot be an anchor for setting the prudent debt target as harmful effects of debt on economic activity are likely to kick in well before.

The anchor of the prudent debt target should therefore be based on the analysis of the impact of debt on the economy. An assessment of the effect of debt on economic activity suggests that beyond a debt threshold, government debt can undermine economic activity and the ability to stabilise the economy. Different channels through which debt can affect the economy are assessed. Empirical evidence gathered from the literature shows that: i) high government debt levels are associated with lower growth (above 80 to $100 \%$ of GDP), though causality is probably running both ways; ii) the ability to stabilise the economy decreases at debt ratios beyond around $75 \%$ of GDP; iii) when a specific role for government debt in financing public infrastructure is taken into account, estimations find a positive but limited "optimal" government debt level at $50-80 \%$ of GDP; and iv) government debt also provides a safe asset in a very liquid market, thus easing liquidity constraints. Therefore, low levels of debt are welfare enhancing.

In addition, the empirical cross-country evidence suggests different debt thresholds, defined as the turning point at which negative effects of debt on the economy kick in, for three groups of countries:

- For higher-income countries, a debt threshold range of 70 to $90 \%$ of GDP.

- For euro area countries, the debt threshold is lower, as they do not control monetary policy. Given the no-bail-out clause, the absence of debt pooling, a higher dependency on foreign financing and difficulties in adjusting to shocks, the debt threshold is $50-70 \%$. 
- For the emerging economies the debt threshold is even lower at 30 to $50 \%$ of GDP as they are exposed to capital flow reversals.

These debt thresholds are used to anchor prudent debt targets. Prudent debt targets should be set to avoid an overshooting of the debt thresholds in the case of large adverse shocks. Prudent debt targets take into account uncertainties surrounding macroeconomic variables and are thus country-specific. Stochastic simulations, which take into account past macroeconomic shocks and fiscal behaviour, indicate prudent debt targets of 15 percentage points of GDP below the debt threshold on average for the advanced OECD as well as the euro area countries, with a considerable cross-country variation.

A well-designed fiscal framework ensures that prudent debt targets are adhered to over the cycle. The fiscal framework should have two objectives: promoting fiscal discipline and permitting stabilisation policies. Five complementary components of the fiscal framework are considered: a debt target, a fiscal rule, fiscal councils, budgetary processes and medium-term budgeting.

In designing the fiscal framework, the prudent debt target should serve as the reference point to define numerical fiscal rules. Fiscal rules should be based on observable variables thus reducing uncertainties, when setting policy. Rules based on estimated variables, such as potential output, are subject to measurement errors that can mislead policy-making. A combination of a budget balance rule and an expenditure rule seems to suit most countries well. A budget balance target encourages hitting the debt target. And, well-designed expenditure rules appear decisive to ensure the effectiveness of a budget balance rule and can foster long-term growth. Moreover, to provide flexibility in the face of large shocks that cause a considerable slippage from the budget balance target, a mandatory minimum debt reduction rule (debt break) can be introduced to guarantee that measures will be taken to offset unexpected increases in the debt level.

Simulations show that the capacity of fiscal policy to mitigate shocks and their adverse consequences on debt trajectory uncertainty varies substantially across countries. In particular, highly indebted countries have less potential to counteract large adverse shocks. However, stronger growth loosens the constraints on fiscal policy that aims at lowering debt to the prudent debt level.

Fiscal councils can underpin transparency and thereby foster fiscal discipline and the credibility of fiscal rules. The adoption of fiscal rules, in particular of complex rules, increases the need for transparency. A fiscal council can also help address the common-pool problem, in particular in federal countries, by pointing out the externalities of fiscal policies generated by sub-central governments that may benefit them at the expense of others. The effectiveness of fiscal rules with regard to the stabilisation objective is enhanced when rules are embedded in a medium-term budgeting framework.

The timing of consolidation, a clear mandate to reform and strong majority support are among the political economy elements that can help overcome "fiscal consolidation fatigue". 


\section{Introduction}

Most OECD countries have seen their government debt rise sharply during the global financial crisis. The OECD weighted average gross financial liability-to-GDP ratio increased from $73 \%$ of GDP in 2007 to $111 \%$ in 2013. It is the highest ratio since the aftermath of the Second World War. Such high debt levels raise questions about their sustainability, and some euro area countries have entered into adjustment programmes in an attempt to control their spiralling debt. The adjustment programmes include important welfare state reforms, and fall hard on the most vulnerable, as illustrated by the explosion of poverty rates in Greece, Portugal and Spain since 2007.

The sharp rise in debt in most OECD countries raises questions about the prudent debt level countries should target. It also raises questions about the fiscal frameworks needed to reach them and to accommodate cyclical fluctuations along the path towards a prudent debt target, creating fiscal space to react to future shocks and taking into account countries' specificities.

In Section 2 of the paper, the pros and cons of using different government debt indicators are reviewed. Section 3 examines why governments should set prudent debt targets. The issue of how to set government debt targets is analysed through three lenses: the sustainability of government debt, the impact of government debt on the economy, and finally the prudent debt level exploring the effects of macroeconomic shocks and other fiscal risks (Section 4). In Section 5, the design and the components of fiscal frameworks are discussed. In particular, fiscal rules, institutions and budgeting processes are studied. In Section 6, the political economy issues that can help overcome "fiscal consolidation fatigue" are analysed.

\section{Gross and net debt definitions: The narrow and the broad}

Government gross financial liabilities and gross debt are the headline indicators of government indebtedness. But such liabilities provide only a partial view of all government liabilities and fiscal risks. For a better assessment of the government fiscal position, the gross debt indicator should be complemented by explicit and probable future liabilities and by defining broader indicators that take into account other liabilities depending on their features (contractual, implicit or contingent). Financial and non-financial assets add further information for a more complete view of current and future government debt sustainability.

Debt data are often a source of confusion, as various definitions, coverage and valuation methods exist. Bloch and Fall (2015) explore the various issues that arise in defining and measuring debt, and examines other data which should be considered, both within and beyond general government debt, to better track and analyse fiscal risks and sustainability issues. Box 1 summarises the main features of various government debt measures. 


\section{Box 1. Debt data: Understanding the terminology}

Differences in headline debt indicators can be confusing. Studies often refer seamlessly to gross debt or gross financial liabilities, net debt or net financial liabilities, without clarifying the terms being used. However, the details do matter, and can affect analyses, comparisons and conclusions. Following the latest Standardised National Accounts framework, Figure 1 highlights the relationships between gross and net debt, and between gross and net financial liabilities as reported in the government financial balance sheet.

Figure 1. The Standardised National Accounts framework for general government debt

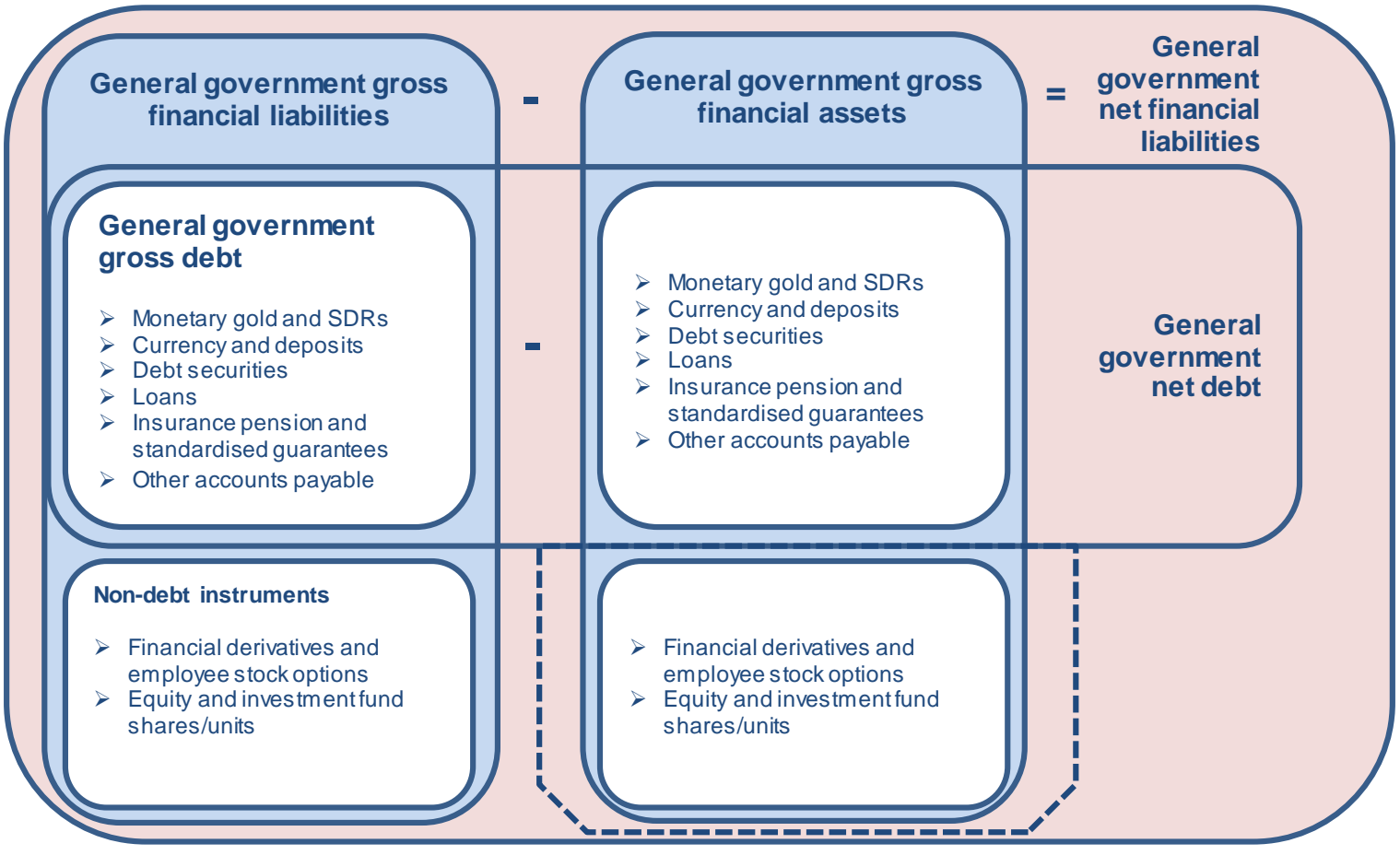

Note: The dotted line highlights an alternative definition of general government net debt, used by the OECD, which takes into account all financial assets, and not only those related to debt instruments, as all financial assets may be used to redeem debt.

The following definitions can be distinguished:

- General government gross financial liabilities: all financial liabilities reported in the National Accounts financial balance sheet for the general government sector.

- General government gross debt: generally defined as all financial liabilities reported on the National Accounts financial balance sheet for the general government sector except "non-debt" instruments (financial derivatives and employee stock options, equity and investment funds).

- $\quad$ General government gross financial assets: all financial assets reported in the National Accounts financial balance sheet for the general government sector.

- General government net financial liabilities: the difference between general government gross financial liabilities and general government gross financial assets.

- General government net debt: the difference between general government gross debt and general government gross financial assets, excluding financial assets pertaining to financial derivatives, employee stock options, equity and investment funds. Alternatively, general government net debt may exclude all financial assets.

- $\quad$ General government net financial worth: the inverse of general government net financial liabilities (general government gross financial assets less general government gross financial liabilities). 


\section{Box 1. Debt data: Understanding the terminology (cont.)}

Within the National Accounts framework, it should be possible to go a step further to calculate general government net worth, taking into account not only financial assets but also the non-financial assets of the general government (Figure 2). In practice, these data are currently only available for a handful of OECD countries. Using flow data, a calculation of the change in government net worth over the past 20 years shows that net worth has declined in many countries and in some by a substantial amount (Bloch and Fall, 2015).

\section{Figure 2. Calculating general government net worth}

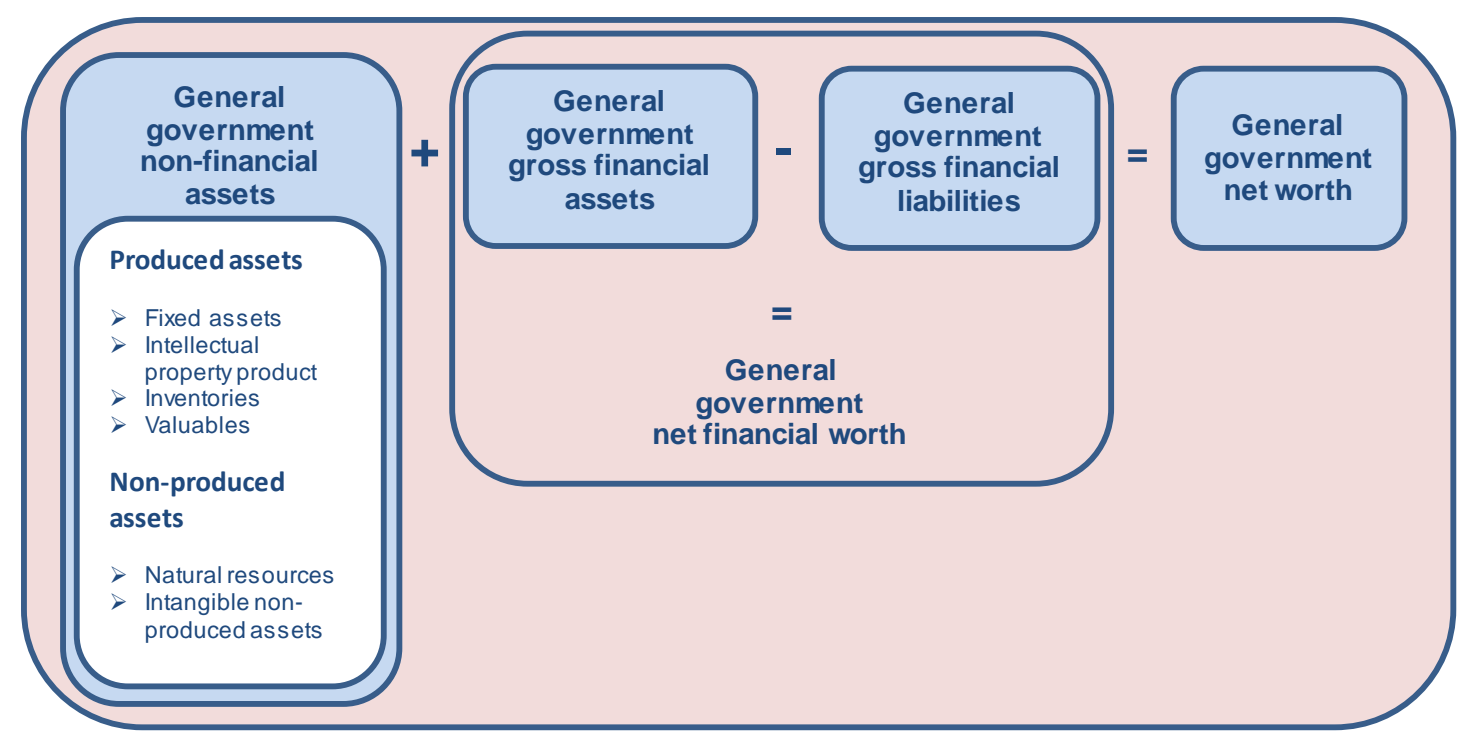

The terminology can therefore be expanded to include:

- $\quad$ General government non-financial assets: produced and non-produced assets of the general government sector as reported in the National Accounts balance sheet for non-financial assets.

- $\quad$ Produced non-financial assets: includes tangible fixed assets such as buildings and machinery, as well as intellectual property, inventories and valuables.

- Non-produced non-financial assets: includes natural resources such as patents, leases and purchased good-will.

Finally, beyond the National Accounts framework, there are a number of future liabilities which are not necessarily accounted for, but which are important for discussions of future pressures on government finances. Contingent liabilities, for example, are of increasing interest to analysts and policy makers. These uncertain liabilities are either explicit - those that are defined by contract or law, or implicit - those for which there is a moral or historical obligation (Figure 3). 
Box 1. Debt data: Understanding the terminology (cont.)

Figure 3. Beyond gross financial liabilities: Accounting for contingent and implicit liabilities

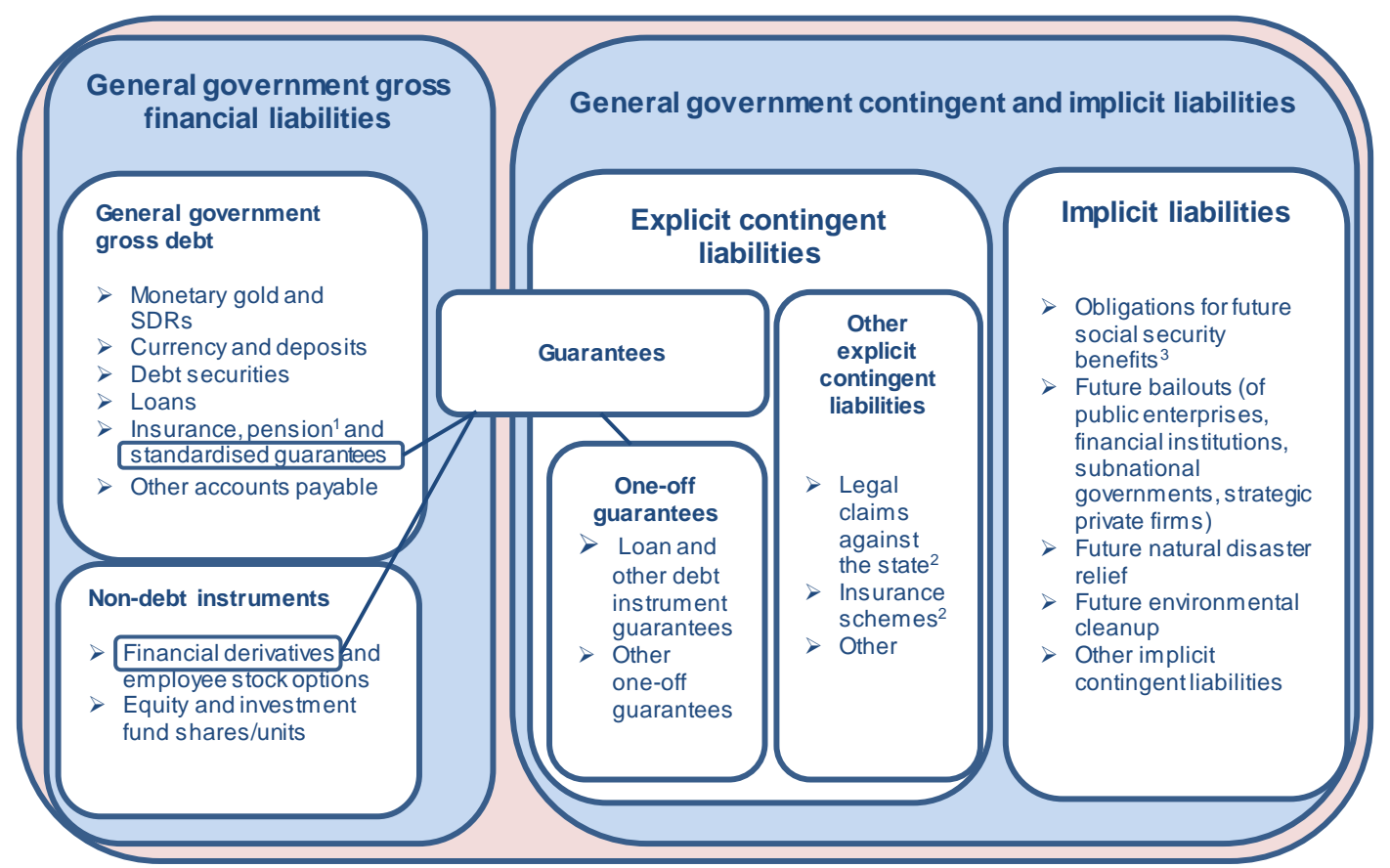

1. Includes explicit unfunded or underfunded civil servant pension liabilities.

2. Refers only to explicit contingent liabilities. In the case of legal claims against the state, this could be claims relating to privatisations, liquidation of agencies, or personnel management. In the case of insurance schemes, this could refer to flood or crop insurance, for example (Cebotari , A.(2008), "Contingent Liabilities: Issues and Practice", IMF Working Paper, No. 08/245.).

3. Excludes explicit unfunded or underfunded civil servant pension liabilities.

The key terms related to these future liabilities follow:

- $\quad$ Contingent liabilities: liabilities which only exist if a certain event occurs. They are recorded if the probability of occurrence is high.

- $\quad$ Explicit contingent liabilities: contingent liabilities defined by contract or law, such as guarantees, deposit insurance schemes, and other legal claims which might be exercised against the state.

- $\quad$ Guarantees: generally related to a loan, refers to an agreement whereby the government agrees to repay any amount outstanding in the event of default. Government guarantees may also refer to price guarantees, exchange rate or revenue guarantees, particularly in relation with public-private partnerships. The probability of standardised guarantees being called is generally calculable, and should be estimated and reported in the National Accounts framework within the financial balance sheet.

- $\quad$ One-off guarantees: guarantees which are particular in nature, and not possible to assess in terms of the risk being called. They are not included in the financial balance sheet.

- Implicit liabilities: future potential liabilities, which are not expressly codified, but where a moral obligation or a historical expectation for the government to act exists. Implicit liabilities include future social security benefits, future bailouts (not covered by current guarantee agreements) or future natural disaster relief.

Currently, only a few countries report their contingent liabilities fully, although there are efforts underway by statistical offices and fiscal councils to provide a fuller picture of future fiscal risks. ${ }^{2}$

1. Earlier National Accounts methodology allows for unfunded or under-funded public employee pension liabilities to be treated as contingent. However, six OECD countries (Australia, Canada, Iceland, New Zealand, Sweden and the United States) record these liabilities on their balance sheets, resulting in debt positions which are overstated relative to those countries where large unfunded or under-funded liabilities for public employee pensions are not yet recorded.

2. See for example, Barnes and Smyth (2013) for Ireland and Eurostat (2015). 
The difference between gross financial liabilities, which include non-debt instruments such as shares and financial derivatives, and gross debt is generally small, while the difference between net financial liabilities and net debt can be significant for some countries (Figure 4). The breakdown of debt and asset instruments also allows for calculating specific indicators as needed, for example to measure debt in relation to only the most liquid assets (Figure 4).

Gross and net financial debt measures remain currently the key indicators for fiscal analysis and surveillance. The gross debt indicator serves to monitor government contractual liabilities, and should be tracked separately from government assets, as sharp swings in asset prices can mask underlying debt developments. The net debt indicator is relevant for solvency analysis, in particular when the government holds liquid assets. Beyond these two headline indicators, comprehensive balance sheets are necessary to evaluate net worth developments (Bloch and Fall, 2015), but are currently available for only a few countries. Implicit and other off-balance-sheet liabilities should also be estimated and monitored to assess fiscal risks (Kopits, 2014), though fiscal risk assessment is still in its infancy (Bloch and Fall, 2015).

Figure 4. Gross and net debt concepts

2012
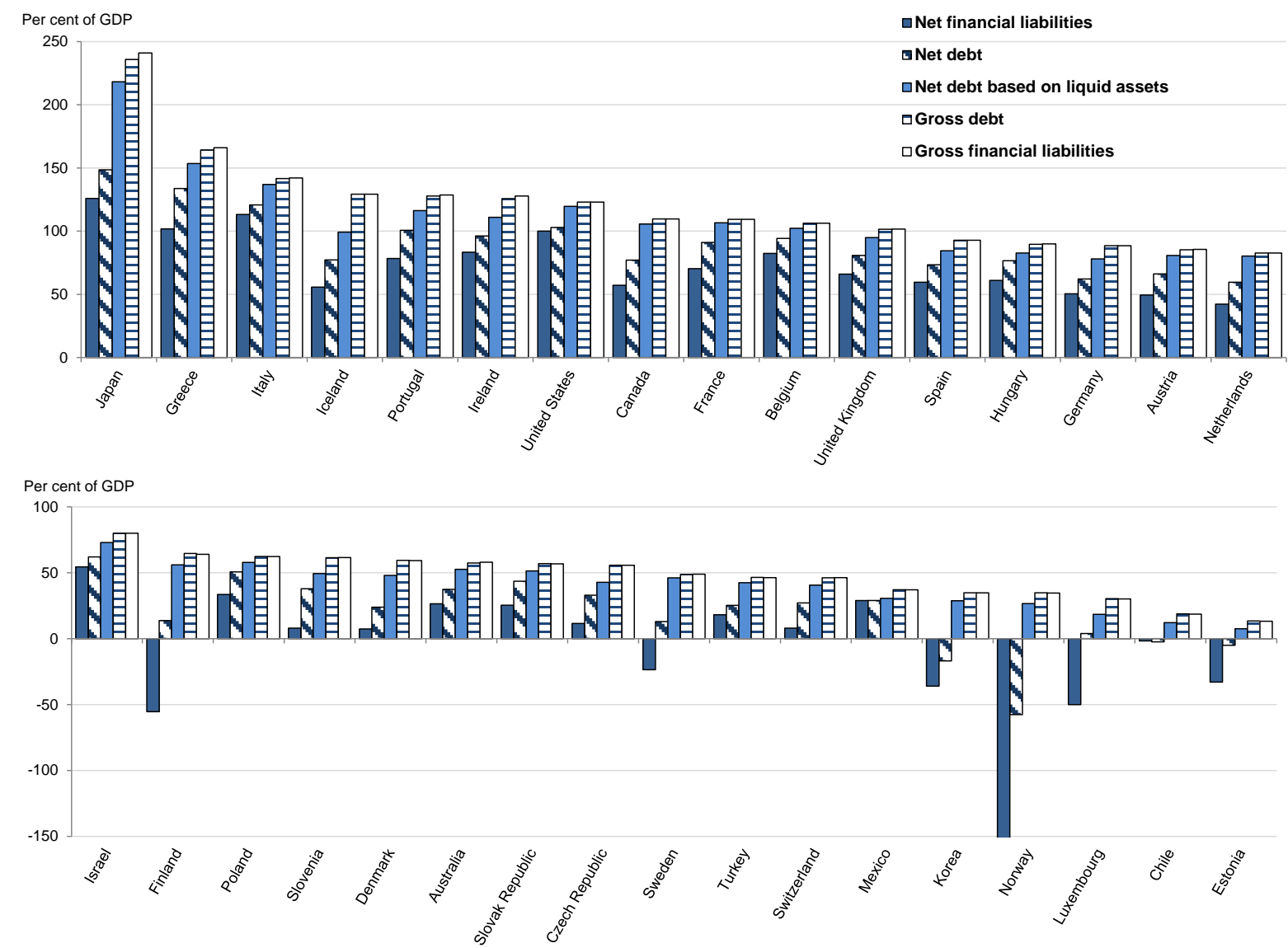

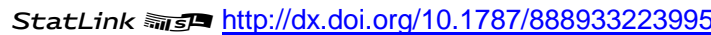
Note: Data for Chile, Japan and Korea are non-consolidated. Data for Mexico refer to 2009 and data for Switzerland to 2011. Data for Iceland may include financial derivatives which were not reported in the National Accounts as such. Data include unfunded pension liabilities for Australia, Canada, Iceland, New Zealand, Sweden and the United States.

Source: OECD (2014), "Detailed National Accounts: Financial balance sheet, consolidated and Financial balance sheet, nonconsolidated", OECD National Accounts Statistics (database), accessed 17 October 2014; OECD Economic Outlook 95 database, June 2014.

Markets do not seem to react more to net financial liabilities than to gross financial liabilities. The market reaction is investigated with regressions determining the long-term interest rate (Table 1). 
Coefficients associated with gross and net debt are very close to each other (Table 1, Columns 1 and 2) after controlling for the inflation rate, past levels of the growth rate, the short-term interest rate and country fixed effects. However, estimations suggest that markets react more to gross debt in euro area countries, while markets are relatively more sensitive to net debt in other OECD countries (Table 1, Columns 3 and 4). This result still holds when looking at the effect of both indicators on the real long-term interest rate (Table 1, Columns 5 and 6).

Table 1. Long-term interest rate determinants

\begin{tabular}{|c|c|c|c|c|c|c|}
\hline & (1) & (2) & (3) & (4) & (5) & (6) \\
\hline Dependent variable & $\begin{array}{c}\text { 10-year } \\
\text { interest rate }\end{array}$ & $\begin{array}{c}\text { 10-year } \\
\text { interest rate }\end{array}$ & $\begin{array}{c}\text { 10-year } \\
\text { interest rate }\end{array}$ & $\begin{array}{c}\text { 10-year } \\
\text { interest rate }\end{array}$ & $\begin{array}{l}\text { 10-year real } \\
\text { interest rate }\end{array}$ & $\begin{array}{l}\text { 10-year real } \\
\text { interest rate }\end{array}$ \\
\hline \multirow[t]{2}{*}{ Core inflation } & 0.079 & 0.078 & 0.084 & 0.080 & & \\
\hline & {$[0.057]$} & {$[0.058]$} & {$[0.057]$} & [0.058] & & \\
\hline \multirow[t]{2}{*}{ Short-term interest rate } & $0.55^{\star \star \star}$ & $0.55^{\star \star \star}$ & $0.55^{\star \star \star}$ & $0.55^{\star \star \star}$ & & \\
\hline & {$[0.037]$} & {$[0.035]$} & {$[0.037]$} & [0.035] & & \\
\hline Short-term real & & & & & $0.63^{\star \star \star}$ & $0.62^{\star \star \star}$ \\
\hline interest rate & & & & & [0.039] & {$[0.037]$} \\
\hline \multirow[t]{2}{*}{ Lag (Real growth) } & $-0.088^{\star \star \star}$ & $-0.090^{\star * *}$ & $-0.081^{\star \star \star}$ & $-0.088^{* \star *}$ & $-0.084^{\star \star \star}$ & $-0.096^{\star \star *}$ \\
\hline & {$[0.022]$} & [0.023] & [0.022] & [0.023] & [0.024] & [0.024] \\
\hline \multirow[t]{2}{*}{ EMU } & -0.28 & -0.27 & $-1.95^{\star \star \star}$ & $-0.49^{*}$ & $-1.65^{\star \star}$ & -0.016 \\
\hline & {$[0.31]$} & [0.30] & {$[0.70]$} & [0.29] & {$[0.76]$} & [0.33] \\
\hline \multirow[t]{2}{*}{ Lag (Gross public debt) } & $0.013^{\star *}$ & & 0.006 & & $0.020^{* \star *}$ & \\
\hline & [0.005] & & [0.004] & & {$[0.005]$} & \\
\hline \multirow[t]{2}{*}{$\begin{array}{l}\text { Lag (Gross public debt) } \\
{ }^{*} \text { EMU }\end{array}$} & & & $0.023^{\star *}$ & & $0.025^{\star *}$ & \\
\hline & & & [0.010] & & [0.010] & \\
\hline \multirow[t]{2}{*}{ Lag (Net public debt) } & & $0.016^{\star \star \star}$ & & $0.014^{\star \star *}$ & & $0.018^{\star \star \star}$ \\
\hline & & {$[0.004]$} & & {$[0.004]$} & & [0.005] \\
\hline Lag (Net Public debt) * & & & & 0.006 & & 0.009 \\
\hline EMU & & & & {$[0.006]$} & & {$[0.006]$} \\
\hline Sample & $1985-2013$ & $1985-2013$ & $1985-2013$ & $1985-2013$ & $1985-2013$ & $1985-2013$ \\
\hline Year fixed effects & no & no & no & no & no & no \\
\hline Country fixed effects & yes & yes & yes & yes & yes & yes \\
\hline N & 624 & 618 & 624 & 618 & 672 & 670 \\
\hline Rho & 0.53 & 0.50 & 0.55 & 0.51 & 0.59 & 0.56 \\
\hline $\mathrm{R}^{2}$ & 0.676 & 0.688 & 0.680 & 0.687 & 0.487 & 0.480 \\
\hline
\end{tabular}

Note: Panel regression with AR(1) Prais-Winsten correction and panel heteroskedasticity-robust standard errors. Standard errors are in parenthesis. ${ }^{* \star *}$ significant at $1 \%$ level, ** significant at $5 \%$ level and * significant at $10 \%$ level.

Source: OECD calculations.

In the following analyses, the focus is on gross financial liabilities as they offer the most complete dataset in terms of country and time coverage and government primary balances have reacted more to gross financial liability changes than to net financial debt variations (Fournier and Fall, 2015). Also, gross financial liabilities are more comparable across countries than financial assets due to valuation and accounting issues.

\section{The effects of debt on the economy}

This section looks at the cross-country evidence on the limits to sustainability, the nexus between debt and growth, the effect of debt-financed public investment on growth and the consequences of debt on the effectiveness of fiscal policy to stabilise the economy. Theory provides little guidance, as the "optimal" debt level depends on model ingredients and assumptions. 


\subsection{Limits to sustainability}

As illustrated by the debt intolerance phenomenon, countries can quickly lose market confidence and see their borrowing rates increase steeply, derailing their debt trajectories. The methodology developed in this section provides a benchmark for debt limits taking into account market reactions.

Following Ghosh et al. (2013), primary balance reaction functions are estimated to determine debt limits, taking into account growth, interest rate developments and the country-specific average fiscal policy stance (Box 2). The public debt limit is defined as the maximum level of debt beyond which the government cannot roll debt over, based on a given growth and risk-free interest rate, a given level of uncertainty, and the previously observed capacity of governments to react to growing debt.

\section{Box 2. Public debt limits}

Public debt limits are calculated based on the framework by Ghosh et al. (2013). In this analysis, the primary balance reaction function is estimated differently from Ghosh et al. (Fournier and Fall, 2015). It uses a different functional form and also post-2007 data are taken into account. Using annual panel data for 31 OECD countries over the period 1985-2013, the fiscal reaction function (primary balance) depends on the debt level and control variables:

$$
\begin{aligned}
P B_{i t}=\beta_{1} G A P_{i t}+\beta_{2} O T_{i t}+ & \beta_{3}\left(D_{i t-1} 1_{D_{i t-1}<d_{1}}+d_{1} 1_{d_{1} \leq D_{i t-1}}\right)+\beta_{4}\left(D_{i t-1} 1_{d_{1} \leq D_{i t-1}<d_{2}}+\left(d_{2}-d_{1}\right) 1_{d_{2} \leq D_{i t-1}}\right)+ \\
& \beta_{5} D_{i t-1} 1_{d_{2} \leq D_{i t-1}}+\beta_{6} O O_{i t}+u_{i}+v_{i t}
\end{aligned}
$$

where $P B_{i t}$ denotes the primary balance of country $i$ at year $t, G A P_{i t}$ denotes the output gap, $O T_{i t}$ denotes the openness ratio multiplied by the terms of trade, $O O_{i t}$ denotes fiscal one-offs, $D_{i t}$ denotes the debt level and $d_{1}$ and $d_{2}$ are estimated thresholds beyond which the fiscal reaction to debt changes. $u_{i}$ are country fixed effects and $v_{i t}$ follows an $\mathrm{AR}(1)$ process.

Estimates (Table A.1 in the appendix) confirm that governments react weakly by increasing their primary balance when debt increases but remains below a certain level ( $d_{1}$ in Figure 5). But, from this threshold $\left(d_{1}\right)$ to a second threshold $\left(d_{2}\right.$ in Figure 5$)$, governments react strongly to rising debt. Beyond this threshold, governments may abandon fiscal discipline and reduce the primary balance. Alternative estimates also capture the effect of the business cycle on the primary balance, and include additional control variables, such as asset prices, inflation, IMF programmes, the old age dependency ratio, the euro area or the government size.

This fiscal reaction function (blue line in Figure 5) is included in the debt dynamics equation and interacted with market reactions (red curve in Figure 5). The interest rate can include a risk premium reflecting the probability of default in the next period $p_{t+1}$, which is the probability that debt $d_{t+1}$ goes beyond its maximum level $\bar{d}$ :

with the following debt accumulation dynamic:

$$
p_{t+1}=P\left(d_{t+1}>\bar{d}\right)
$$

$$
d_{t+1}=\left(1+r\left(p_{t+1}\right)-g\right) d_{t}+\mu+f(d)+\varepsilon_{t}
$$

where $g$ denotes the potential growth rate, $\mu$ denotes an average stance of fiscal policy, $f(d)$ the reaction of the primary balance to debt and $\varepsilon_{t}$ captures macroeconomic shocks to the primary balance. The debt limit is a function of the interest rate-growth rate differential $r_{i}-g_{i}$, the shock size $V\left(\varepsilon_{i}\right)$, and the average past primary surplus $\mu_{i}$. 


\section{Box 2. Public debt limits (cont)}

Debt stabilises when the effect of past debt accumulation is exactly offset by the primary balance, as illustrated in Figure 5. There is a stable equilibrium $\underline{d}$ for which the government would generate a higher surplus if a shock increases the debt ratio. By contrast, when the debt level approaches the debt limit, then the government is facing an interest rate spiral (green curve in Figure 5), and at the debt limit, the interest rate goes towards infinity, which means that the government loses market access.

Figure 5. Determination of the debt limit

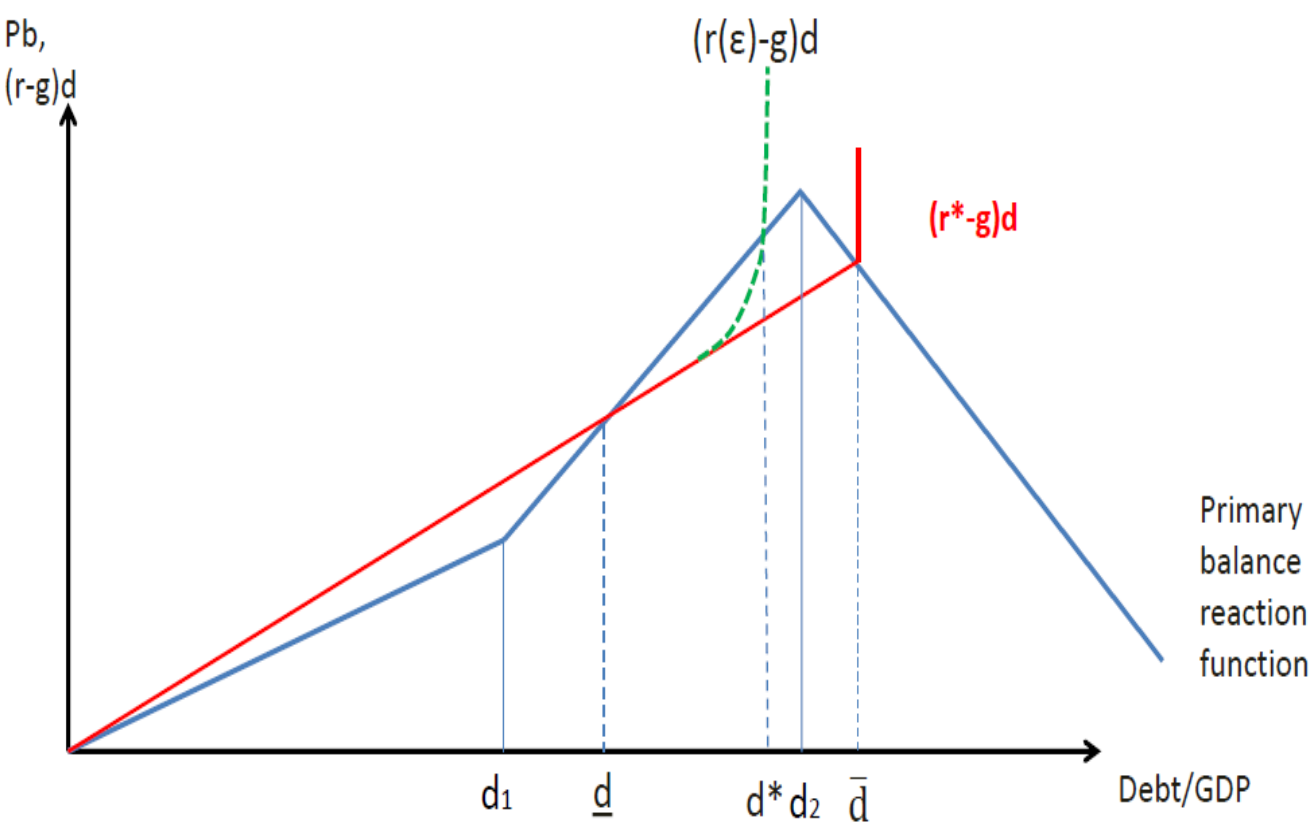

Note: $\mathrm{g}$ is the growth rate, $\mathrm{r}$ is the interest rate, $r^{*}$ is the risk-free interest rate, $r(\varepsilon)$ is the interest rate with a risk premium, pb is the primary balance, $d$ is the debt-to-GDP ratio, $\underline{d}$ is the equilibrium debt-to-GDP ratio, $d^{*}$ is the stochastic debt limit depending on the probability of default and $\bar{d}$ is the deterministic debt limit corresponding to the intersection between the risk-free interest payment and the fiscal reaction function. $d_{1}$ and $d_{2}$ are two estimated thresholds signalling changes in the reaction function to increasing debt.

The model is solved for each country to calculate current debt limits. The real long-term interest rate is the 10year government bond yield minus core inflation and the real risk free rate is set by deducting the CDS risk premium from the real interest rate. The growth rate is the average potential growth rate between 2014 and 2017. The size of macroeconomic shocks is derived from the standard deviation of the output gap. The past primary surplus is gauged by country-specific fixed effects plus the median of residuals.

The gap between the interest and growth rate plays a large role in explaining differences in the debt limit across OECD countries, especially for the countries that depart most from the OECD average (Figure 6). 


\section{Box 2. Public debt limits (cont)}

Figure 6. Debt limit drivers

Deviation of the debt limit from the OECD average in per cent of GDP

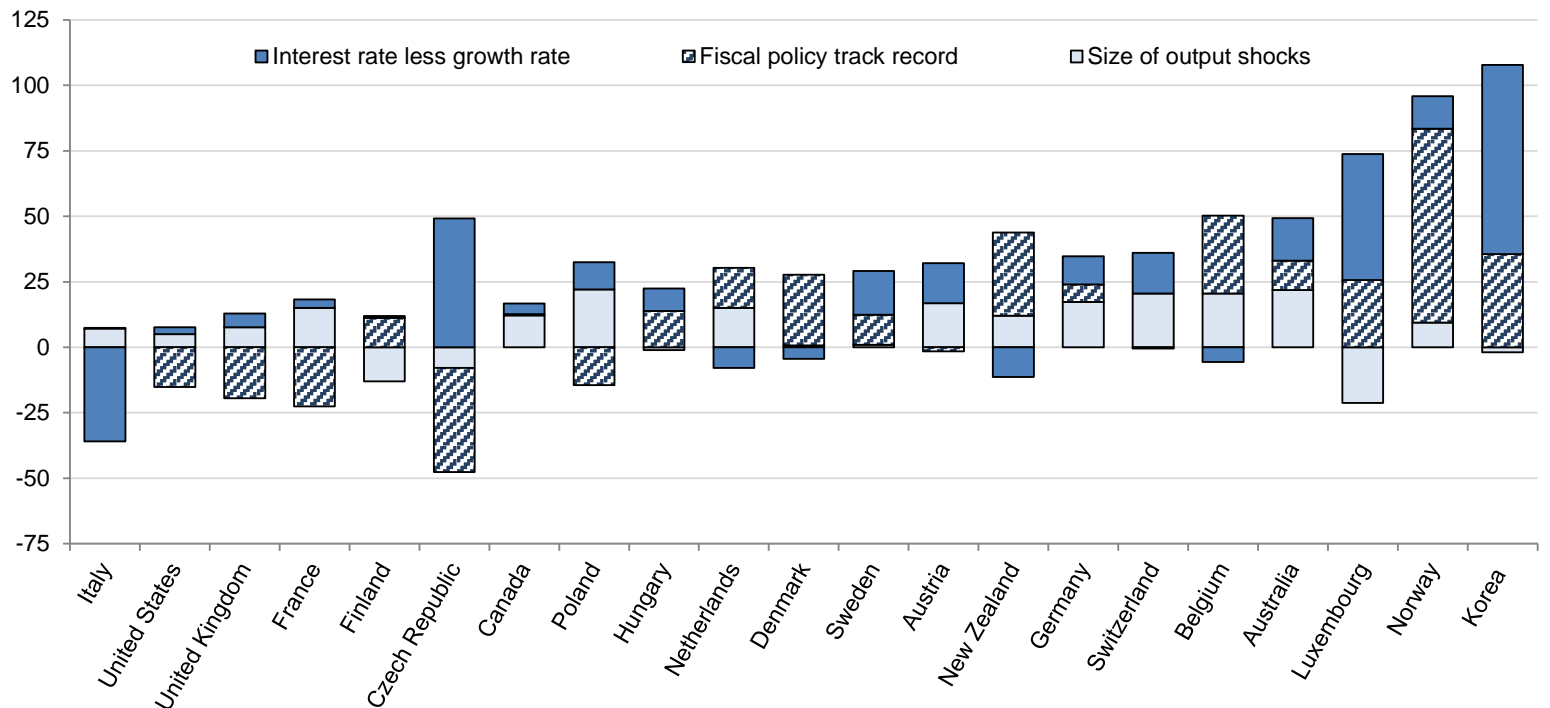

StatLink त्राज http://dx.doi.org/10.1787/888933224007 Note: This figure compares the debt limit of a given country to the $200 \%$ debt limit that would prevail in a virtual OECD average country, in which each determinant is equal to the corresponding OECD average. Contributions are debt limit differences associated with replacing a country-specific characteristic by the corresponding OECD average. For some countries no solution exists. For more details on this decomposition, see Fournier, J-M. and F. Fall (2015), "Limits to Government Debt Sustainability", OECD Economics Department Working Papers, No. 1229, OECD Publishing.

Source: OECD calculations.

Debt limits are close to twice GDP in many OECD countries (Figure 7). This reflects that at medium to high debt, the primary balance surplus reaction to debt is large. Those high debt limits are due to the few countries which have high debt (Japan and Greece). ${ }^{1}$ Differences in debt limits between countries depend strongly on the fiscal behaviour of governments. ${ }^{2}$ Maximum debt levels are higher in countries with a solid fiscal policy track record (e.g. Norway), and lower in countries with low potential growth relative to the risk free interest rate (e.g. Italy).

In some countries (Greece, Iceland, Ireland, Japan, Portugal, Spain, Slovenia and Slovak Republic), there is no model based interest rate solution for a debt limit. It means that, given past fiscal behaviour, the debt dynamics is not sustainable. These countries need to change fiscal behaviour by improving the primary balance in the future to bring their debt dynamics onto a sustainable path. It also suggests high market volatility to any news affecting these countries.

1. The high threshold beyond which fiscal fatigue kicks in is determined by the combination of the strong fiscal policy reaction to debt by Greece, Italy and Portugal on the one hand and Japan's weak reaction on the other hand. This high debt limit is also due to the low current risk-free interest rate compared with the longterm potential growth rate in many OECD countries.

2. Ballagria and Martinez-Mongay (2009) show that the fiscal reaction to debt was stronger in the euro area countries in the run-up to monetary union than afterwards. 
In 2013, Japan's debt is higher than the debt limit based on the current interest rate while there is no solution for the model based interest rate, if past fiscal behaviour prevails. Different factors explain why the debt limit has not been binding: the central bank has kept the interest rate close to zero for a long period, a strong home bias exists, underpinned by holdings of public pension reserve funds, and the net financial assets position of the country is large.

Figure 7. Debt limits

Government financial liabilities, per cent of GDP

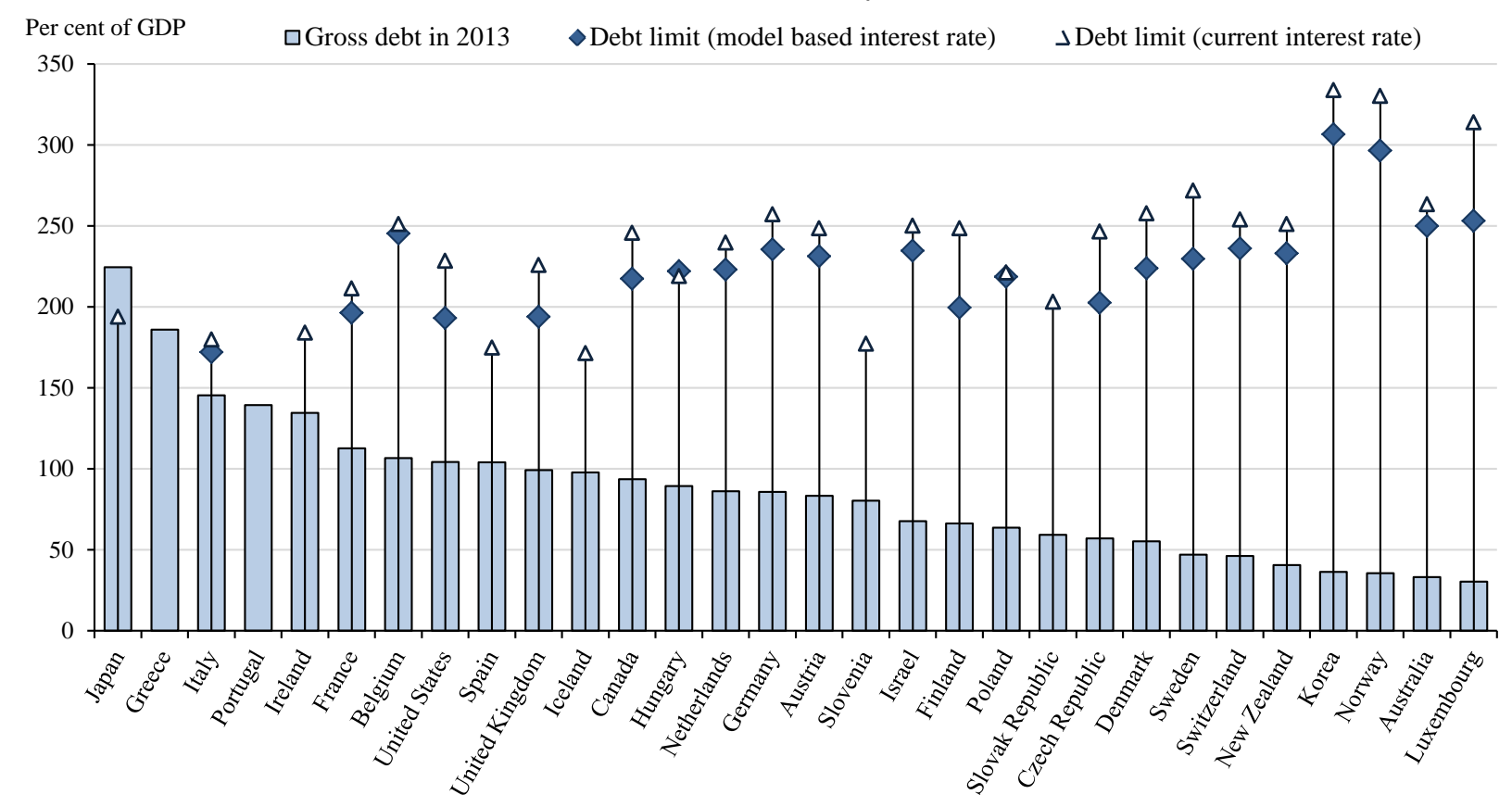

StatLink s-iाs http://dx.doi.org/10.1787/888933224011 Note: If past fiscal behaviour prevails, there is no finite interest rate solution to calculate the model based debt limit for Greece, Ireland, Iceland, Japan, Portugal, Slovenia and Spain, and there is no stable debt level at current interest rates for Greece and Portugal.

Source: OECD calculations.

The debt limit based on market interest rates provides an upper bound because it does not take into account the rise of the interest rate as debt approaches its limit. That is why it is higher than debt limits built on a model-based interest rate, which takes into account the interest rate-debt spiral.

However, the debt limit is a moving target as it can be reached quickly, if a country loses market confidence or if macroeconomic conditions change sharply (e.g. a change in the rate of potential growth or in the size of shocks). Therefore, any debt target should be lower than such debt limits as uncertainties surrounding the underlying hypothesis (e.g. on long-term growth rates) and the risk of interest rate spirals call for a substantial buffer.

The risk that fiscal space vanishes is well illustrated by the following mechanisms:

- Estimated debt limits crucially depend on past fiscal behaviour: deteriorating fiscal balances not only push public debt up, but also push the debt limit down.

- An increase in the gap between the risk free interest rate and the potential growth rate that is plausible by historical standards could force governments to change fiscal behaviour to remain on a sustainable track. An increase (decrease) in the potential growth rate improves (worsens) the debt limit: a one percentage point higher potential growth rate increases the debt limit by about $25 \%$ of GDP. In the case of a large permanent decrease of potential growth without a 
commensurate decrease of the risk-free interest rate, the fiscal space could also vanish unless the government changes its behaviour. Fournier and Fall (2015) show debt limits for different combinations of the interest rate/potential growth differential.

- The fiscal behaviour of countries with high debt levels varies. In particular those under market pressure (e.g. euro area countries) have to generate primary surpluses, while those under no pressure (e.g. Japan) may even widen the primary deficit, although their debt is already very high.

\subsection{The debt level that maximises growth}

Building on the initial work by Aschauer (2000), Checherita-Westphal et al. (2014) and Strasky (2015) use a simple growth model with private and public capital to illustrate the role and size of government debt in a long-run perspective. The main assumption is that government spending follows the "golden rule", that is public debt is used exclusively to finance net investment, while taxes finance current spending. In the long run (steady-state), there is a constant public-to-private capital ratio that maximises growth. According to the "golden rule", the optimal stock of public capital equals the stock of public debt in the long run.

According to this model, the "golden rule" implies a non-linear relationship between the optimal ratio of public-to-private capital stock and the "optimal" debt-to-GDP ratio:

$$
b^{*}=\varphi^{*(1-\alpha)}=\left(\frac{\alpha}{(1-\alpha)^{2}}\right)^{1-\alpha}
$$

where $b^{*}$ is the optimal debt-to-GDP ratio, $\varphi^{*}$ the optimal public-to private capital ratio and $\alpha$ the elasticity of output with respect to public capital.

Hence, the estimation of the elasticity of output with respect to public capital, and the assumption of the "golden rule" allow comparing the actual government debt-to-GDP ratio to a simple long-run benchmark.

New empirical evidence suggests that the elasticity of output with respect to public capital is 0.23 across 22 OECD countries and slightly higher, at 0.26 , in 11 euro area countries (Strasky, 2015). ${ }^{3}$ These values imply a somewhat higher return on public investment in the euro area countries than in the 22 OECD countries, resulting in a higher long-run public capital stock. Conversely, the results of Checherita-Westphal et al. (2014) suggest a lower return on public capital in Europe and hence a lower optimal public capital stock than the average across the OECD.

Optimal debt levels are considerably lower than the actual debt-to-GDP ratios in many OECD countries (Table 2). The main conclusion of this exercise is that the growth-maximising debt level falls between $50-80 \%$ of GDP. However, the results should be interpreted with caution as they rest on the strong assumption about debt financing (the "golden rule") and it is not clear whether debt financing of public investment is the first-best option, as the "golden rule" asserts.

3. Country-specific estimations of the output elasticity are not significant for half of the countries. This is likely due to the small sample size at the country level. 
Table 2. Estimations of the growth maximising long-run debt-to-GDP ratio

\begin{tabular}{l|c|c|c}
\hline & OECD 22 & EU 14 & Euro area 11 \\
\hline Checherita-Westphal et al. & 65.5 & 63.5 & 49.6 \\
& {$[50 ; 81]$} & {$[45 ; 82]$} & {$[27 ; 72]$} \\
Strasky, including housing & 48.9 & 49.9 & 55.9 \\
capital stock & {$[24.5 ; 73.2]$} & {$[22.2 ; 77.5]$} & {$[20.1 ; 91.7]$} \\
Strasky & 65.1 & 72.9 & 83.7 \\
& {$[42.0 ; 88.2]$} & {$[46.3 ; 99.5]$} & {$[47.9 ; 119.5]$} \\
\hline
\end{tabular}

Note: Strasky, J. (2015), "Public Capital Stock and the Debt-to-GDP Ratios in 22 OECD Countries", OECD Economics Department Working Papers, forthcoming and Checherita-Westphal, C., A. H. Hallett and P. Rother (2014), "Fiscal Sustainability Using Growthmaximizing Debt Targets", Applied Economics, Vol. 46(6), pp. 638-647 use a different estimation methodology. The borders of the confidence interval are in brackets.

\subsection{The effectiveness of fiscal policy in stabilising the economy}

The impact of debt on the economy has been mostly analysed through the effects of changes in fiscal policies on output. It is measured by fiscal multipliers, which show the effect of a change in a fiscal instrument on economic activity.

The empirical evidence on the size of the multipliers is not conclusive, as multipliers depend on whether policy focuses on spending or taxes, whether policy changes are temporary or permanent, whether stimulus is provided in good or bad times, whether many households face liquidity constraints, on monetary policy, the credibility of government and many other factors (Galí et al. (2007); Auerbach and Gorodnichenko (2012); Blanchard and Leigh (2013); Ramey (2011)).

The level of debt also matters for fiscal policy effectiveness. Röhn (2010) provides an overview of recent studies on Ricardian equivalence. The private/public saving offset of fiscal policy changes is larger in the long term than in the short term. However, estimates vary considerably across the studies. The estimates of the private saving offset for OECD countries ranges from 0.1 to 0.5 in the short run, and from about 0.3 to as much as 0.9 in the long run.

The OECD's own estimations that take into account cross-country heterogeneity show that on average across countries the savings offset is around $40 \%$, both in the short and in the long term (Röhn, 2010). However, there is considerable heterogeneity across countries. Overall, his results provide evidence against a strict version of the Ricardian equivalence hypothesis in the long term (full offset). Moreover, offsets may also react in a non-linear way. Saving offsets become stronger at a tipping point of government debt at around $75 \%$ of GDP.

More recently, Nickel and Tudyka (2014) find for a sample of 17 European countries that responses of output to government spending shocks exhibit strong non-linear behaviour. They find that the overall cumulative effect of a spending shock on GDP is positive at moderate debt-to-GDP ratios, but the effect turns negative beyond debt ratios of $65 \%-70 \%$.

This non-linear effect of fiscal stimulus is also confirmed by Turner and Spinelli (2013) who show that the interest rate effect of marginal increases in external or government debt is non-linear and depends on the level of debt. For instance, the interest rate effect has risen sharply in the post-crisis period for euro area countries, which have a combination of both high external and government debt.

\subsection{When does debt affect growth?}

A high level of debt not only lessens the effectiveness of fiscal stimulus, it can also reduce growth. Reinhart and Rogoff's (2010) conjecture that debt above 90\% of GDP has a negative impact on growth, has prompted much empirical work to investigate the relationship between debt and growth. Some studies, such as Kumar and Woo (2010) and Cecchetti et al. (2011) find some evidence of a non-linearity, with high 
levels of debt having a larger negative impact on growth. In particular, Cecchetti et al. (2011) find that government debt has a negative impact beyond a range of 80 to $100 \%$ of GDP. Moreover, Baum et al. (2013), focusing on 12 euro area countries, estimate that beyond debt-to-GDP ratios of 95\%, additional debt has a negative impact on economic activity. They also find that the long-term interest rate is subject to increased pressure when the public debt-to-GDP ratio rises above $70 \%$.

However, work by the OECD indicates that a universal non-linear relation between debt and growth is not robust (Égert, 2013). For general government debt, the threshold beyond which negative growth effects kick in is at about $50 \%$ and there is a large amount of cross-country heterogeneity. Also Afonso and Alvés (2014) find different thresholds for the debt-growth relationship for some EU countries.

Finally, Chuddik et al. (2013) estimate long-run effects in dynamic heterogeneous panel data, taking into account the possibility of reverse causality. They show that some economies have run into debt difficulties and experienced subdued growth at relatively low debt levels, while others have been able to sustain high levels of indebtedness for prolonged periods and grow strongly without experiencing debt distress. They do not find a universal threshold effect in the relationship between debt and growth. However, there is a statistically significant threshold effect in the case of countries with rising debt-to-GDP ratios. The debt trajectory seems more important than the level of debt itself.

Overall, there is good reason to believe that causation between higher debt and lower growth runs both ways and the empirical literature has not come to a strong conclusion on causality (Panizza and Presbitero, 2014).

\section{Defining debt targets}

This section summarises the cross-country evidence of the effect of debt on the economy, and comes up with debt thresholds, distinguishing between advanced economies with an autonomous monetary policy, for the euro area countries and for lower income economies. It also reviews hard-to-quantify risk factors. Finally, stochastic simulations are provided to show the amount of prudence needed to reach a specific debt target with a certain probability.

\subsection{Finding a debt threshold: Cross-country evidence}

From the review of the cross-country evidence of the links between government debt and economic activity, the following can be gleaned:

- At moderate levels, government debt plays a positive role for the functioning of domestic financial markets as it provides a safe asset in a very liquid market. It is difficult to pin down the size of this positive effect and when diminishing returns set in.

- Debt also plays a positive role when it funds public infrastructure, but only up to a point. The analysis suggests that this point lies between 50 and $80 \%$ of GDP for OECD countries.

- Empirical estimates of non-linear effects of debt on growth, though controversial, show that negative effects of debt on growth are likely to emerge for debt-to-GDP ratios above $80 \%$ to $100 \%$ of GDP.

- Röhn (2010) showed that at higher debt, private saving offsets of fiscal stimuli become stronger, with a tipping point estimated around 75\% of GDP. Also, Nickel and Tudyka (2014) find that the overall (short and long-run) effect of spending shocks becomes negative beyond debt ratios of $65 \%$ to $70 \%$.

- Sustainability limits are hard to pin down, but are high for many countries. Japan illustrates that some countries can have a high level of debt for a long time period without adverse market reactions, as the Japanese economy is characterised by a high household saving rate, low external financing and a large amount of external financial assets. The fiscal limit exercise suggests that a country may only be able to live with very high debt as long as interest rates are 
low and market confidence is high. This suggests that such an equilibrium is likely to become unstable. Because debt limits are state dependent, countries should endeavour to steer clear of their default limit.

\section{Advanced economies}

Overall, these estimates suggest a gross debt threshold range, where negative effects of debt start to dominate, of 70 to $90 \%$ of GDP for higher-income countries, with specific risk exposures to factors such as foreign debt, bank fragilities, etc., to be taken into account (see below). ${ }^{4}$

Different lessons can be drawn from the recent experience of advanced countries compared with past developing and emerging country debt crises. First, the debt intolerance phenomenon that kicked in for developing and emerging countries at low levels of debt may also affect advanced countries though at higher levels of debt. Duress involves a vicious cycle of loss of market confidence, rising interest rates on government debt, and difficulties to service debt, potentially leading to default or restructuring. This scenario is clearly what happened in the euro area in Greece and its contagious effects. Second, as some advanced countries are more and more dependent on capital inflows and international markets for their debt financing, they are more vulnerable to global factors that could reverse financing flows and shake market confidence. Finally, in advanced economies fiscal risks are linked to financial markets crises originating either internally or externally.

Recent events suggest that debt thresholds for euro area countries are lower than for the other advanced OECD economies, because they are constrained by the absence of a country-level monetary policy. Federal countries can provide insights for countries in a monetary union. In federations two countervailing forces exist. On the one hand, tight economic and monetary integration can make for high shock absorption capacity, as shown by large federal countries such as Canada, Germany and the United States (Hepp and von Hagen, 2009 or Carlino and Inman, 2013). On the other hand, the sharp reaction of financial markets to crises in small sub-national jurisdictions suggests that even small events can have severe disruptive effects, giving credence to the argument that contagion poses a considerable threat in an integrated economy (Blöchliger, 2013). The net effect of setting risk-spreading integration against risk-creating contagion should tilt the euro area country debt targets in the direction of prudence, as global capital flows freely in the euro area, leading to contagion risks, while labour and goods markets are less well integrated, making adjustment to shocks tougher and more long-lasting than in mature federations. These considerations would suggest that the debt threshold for euro area countries is in a range of 50 to $70 \%$ debt to GDP, though the "right" threshold is difficult to establish.

\section{Emerging economies}

Developing and emerging countries tended to default at a relatively low level of debt. Among default episodes between 1970-2008 reported by Reinhart and Rogoff (2009), more than half of all defaults occurred at levels below $60 \%$. A striking feature of these defaults was that liabilities represented on average $230 \%$ of exports and a sizable portion of government revenues. This points to two vulnerabilities: first, borrowing was no longer in line with the exports needed to generate foreign currency with which to service foreign currency debt; second, governments had limited capacity to collect revenues signalling institutional weaknesses.

Vulnerabilities are also due to global factors. As noted by Reinhart and Rogoff (2009), peaks and troughs in commodity price cycles appear to be leading indicators of peaks and troughs in the capital flow

4. The establishment of this debt threshold range is not based on a complete meta-analysis of all studies and there is no weighting of the various links between debt and economic activity. 
cycle, with troughs typically resulting in multiple defaults. One lesson is that countries experiencing sudden large capital inflows are at high risk of experiencing a sovereign debt crisis. ${ }^{5}$

Major financial crises are often key ingredients in sovereign defaults. The combination of bank failures and recessions can trigger sovereign crises. Arellano and Kocherlakota (2008) find that domestic private sector default risks are positively correlated with sovereign default risk. And sovereign defaults are often associated with large numbers of domestic defaults, such as bank insolvencies. Reinhart and Rogoff (2011) also confirm the link between domestic financial sector problems and sovereign debt crises.

Since the financial and debt crises of the 1990s, the fiscal performance of the emerging and lowerincome OECD economies has improved. Thanks to these improvements and stronger growth they fared better during the recent crisis and were less affected in terms of sovereign debt problems. Indeed, most of the emerging economies have a low level of debt, except Brazil and India, which have debt ratios above $60 \%$. The government finances are less vulnerable to external developments thanks to low external borrowing (on average less than 10\% of GDP) and higher foreign currency reserves, matching or even higher than their external indebtedness for most of them (Table 3).

However, some risks to the public finances appear high in some countries. For instance, Brazil is heavily exposed to future public spending on pensions due to the indexation of pension benefits to a fast rising minimum wage while the population is aging rapidly. India's government appears exposed to public enterprise risks, while the financial sector seems weak (Table 3). The budgets in several countries (Colombia, Mexico and Russia) are heavily exposed to adverse oil price shocks.

Moreover, the financial sector and the exchange rate of most of these countries appears to be highly sensitive to monetary policy changes in advanced countries, especially non-conventional policies of the United States and its impact on the dollar. The volatility of capital flows remains high indicating that despite their better performance, there are still vulnerabilities. Emerging economies remain exposed to the debt intolerance phenomenon. Reinhart and Rogoff (2011) find that when external debt of emerging markets is above $30-35 \%$ of GDP, risks of a credit event start to increase significantly. This implies that fiscal space is much more limited than in the advanced economies, although the need for infrastructure investment is high. Taking into account the various risk factors and especially external debt, the quantity of foreign reserves, the expected interest rate and growth differential and the maturing of health and pension schemes, emerging economies debt threshold is probably in a range of 30 to $50 \%$ debt to GDP ratio.

5. Aguiar and Amador (2013) provide a survey of the channels that lead to sovereign debt defaults. 
PRUDENT DEBT TARGETS AND FISCAL FRAMEWORKS

Table 3. Fiscal performance and risk indicators for emerging and lower income economies ${ }^{1}$

\begin{tabular}{|c|c|c|c|c|c|c|c|c|c|c|}
\hline Indicator & Chile & Colombia & Mexico & Turkey & Brazil & Russia & India & Indonesia & China & South Africa \\
\hline \multicolumn{11}{|l|}{ Fiscal performance indicators } \\
\hline $\begin{array}{l}\text { Financial balance } \\
\text { (\% of GDP) }\end{array}$ & -3.4 & $-2.4^{4}$ & -0.3 & -0.8 & -3.3 & -0.5 & -7.9 & -2.2 & -0.7 & -6.1 \\
\hline $\begin{array}{l}\text { Primary balance } \\
\text { (\% of GDP) }\end{array}$ & 0.2 & 0.8 & -0.5 & 0.8 & 1.9 & 0.3 & -3.8 & -1.4 & -1.5 & -1.8 \\
\hline $\begin{array}{l}\text { Interest payments } \\
\text { (\% of revenue) }\end{array}$ & 2.7 & 9.5 & & 9.2 & 21.7 & 1.8 & 24.9 & 10.9 & 3.3 & 9.6 \\
\hline Debt (\% of GDP) & 11.1 & 32.0 & 43.5 & 35.5 & 67.2 & 10.4 & 66.4 & 23.6 & 21.3 & 42.7 \\
\hline External debt (\% of GDP) & 2.1 & 9.4 & 16.4 & 10.8 & 2.8 & 2.9 & 4.0 & 13.1 & n.a. & 14.8 \\
\hline \multicolumn{11}{|l|}{ Fiscal risk indicators } \\
\hline $\begin{array}{l}\text { Public ownership of enterprises } \\
\text { (PMR indicator) }\end{array}$ & 2.24 & 2.3 & 2.59 & 3.55 & 2.68 & 3.94 & 4.50 & n.a. & 4.15 & 3.39 \\
\hline Terms of trade (Volatility) ${ }^{2}$ & 0.128 & 0.068 & 0.022 & 0.032 & 0.055 & 0.154 & 0.019 & 0.046 & 0.048 & 0.034 \\
\hline $\begin{array}{l}\text { Non-performing loans } \\
\text { (to total gross loans (\%)) }\end{array}$ & 2.1 & 2.8 & 3.2 & 2.6 & 2.9 & 6.0 & 3.8 & 1.7 & 1.0 & 3.6 \\
\hline Bank capital-to-assets (\%) & 8.1 & 14.8 & 10.4 & 10.9 & 9.3 & 11.5 & 6.9 & 12.5 & 6.7 & 7.9 \\
\hline $\begin{array}{l}\text { Bank regulatory capital to risk- } \\
\text { weighted assets (\%) }\end{array}$ & 13.3 & 17.0 & 15.6 & 15.3 & 16.1 & 13.5 & 12.3 & 19.8 & 12.2 & 15.6 \\
\hline $\begin{array}{l}\text { Future public spending on } \\
\text { pensions (change in \% points } \\
\text { of GDP 2010-50) }\end{array}$ & n.a. & n.a. & 1.1 & 4.1 & 7.3 & 0.4 & n. & 1.2 & 0.4 & 0.2 \\
\hline $\begin{array}{l}\text { Future public spending on } \\
\text { health and long-term care } \\
\text { (Increase in \% points of GDP } \\
2010-30 \text { ) }\end{array}$ & 3.2 & n.a. & 2.8 & 2.7 & 2.4 & 1.7 & 1.6 & 2.0 & 2.1 & 1.5 \\
\hline $\begin{array}{l}\text { Projected interest rate-growth } \\
\text { differential }(\%)^{3}\end{array}$ & 0.1 & 1.5 & -0.2 & 0.2 & 2.4 & -1.2 & -4.5 & -5.2 & -7.7 & -2.1 \\
\hline $\begin{array}{l}\text { Foreign currency reserves } \\
(\% \text { of GDP) }\end{array}$ & 14.1 & 10.9 & 13.3 & 13.3 & 15.5 & 21.6 & 14.2 & 10.6 & 40.7 & 11.9 \\
\hline Exchange rate (Volatility) & 0.06 & 0.08 & 0.07 & 0.08 & 0.11 & 0.09 & 0.07 & 0.07 & 0.03 & 0.11 \\
\hline
\end{tabular}

1. Data refer to general government accounts for 2013 or for the latest year available.

2. Terms of trade and exchange rate volatility are calculated as the standard deviation of annual percentage changes from 2004-13.

3. IMF projection 2013-18

4. Central government. 


\subsection{Debt and the vulnerabilities of countries to specific factors and risks}

Fiscal risks due to explicit and implicit contingent liabilities are discussed in Bloch and Fall (2015). Countries are also exposed to other specific risks, the prevalence and size of which is often difficult to quantify. Yet, these specific risks as well as the explicit and implicit contingent liabilities should be taken into account, when establishing the prudent debt target.

\section{Total indebtedness and asset price movements}

High total indebtedness can create vulnerabilities to shocks, exposing not only households and firms, but also governments to maturity, currency and liquidity mismatches as well as potential solvency problems (Sutherland and Hoeller, 2012). Furthermore, high indebtedness can expose the economy to asset price movements, which can amplify shocks and macroeconomic instability. Government debt typically rises after the onset of a recession, suggesting that there is a migration of debt across balance sheets. This is confirmed by the latest IMF (2014) accounting of financial sector support by governments. Since the onset of the crisis up to early 2014 , the net impact of support to the financial sector on gross public debt was $24 \%$ for Greece and $33 \%$ for Ireland. However, most of the impact of a financial crisis on government debt is not due to bank bailout costs but due to a sharp decline in tax revenue due to the deep recession and ensuing hysteresis effects that accompany severe financial crisis (Reinhart and Rogoff, 2009; Ollivaud and Turner, 2014).

The vulnerabilities of budgets to financial and housing sector developments can be partly gauged by the effects of asset price cycles on the budget. Price and Dang (2011) find that budgets of some countries are very sensitive to house price cycles, which can account for budget balance swings of up to $3 \%$ of GDP in either direction, notably in Ireland, the Netherlands and Spain. Equity price cycles tend to have a smaller impact in almost all countries (apart from Korea and Australia). Turner (2006) analyses how commodity prices affect the government balance in Australia. For countries relying strongly on some commodity exports, there is a risk of commodity price bubbles and trend reversals that can have a considerable effect on budget balances and therefore debt.

\section{Taxation}

A high level of taxation constrains the options to respond to a surge in debt. Among the countries with a debt-to-GDP ratio above 100\%, France, Belgium and Italy have the highest level of current receipts amounting to close to $50 \%$ of GDP or more. In contrast, the United States and Japan, which also have a high debt ratio, have government receipts below $35 \%$ of GDP. They have more room to raise taxation to reduce debt than the countries with an already high tax burden and Japan has started to raise the valueadded tax with the aim of reining in spiralling government debt.

\section{Population ageing}

Population ageing is due to accelerate in the coming years with the old-age ratio (working-age population over those older than 65 years) decreasing from 4.2 currently to 2.1 in 2050 in the OECD on average. This development is particularly detrimental for pension schemes. It also affects health care spending, but to a lesser degree, with health technology developments playing a prominent role, but ageing has a strong effect on long-term care. Future public health care and pension spending pressures could be considerable in many OECD countries (Fall et al., 2014). Pension systems need to be reformed to make them sustainaible and efficiency gains be sought in health care systems. The remaining future spending pressures will have to be matched by additional resources or by cuts of other government spending items.

\section{The composition of government debt}

The composition of government debt can also have macroeconomic impacts (Lojsch et al., 2011). For instance, in advanced economies, the government bond yield curve serves as a benchmark for pricing private sector bonds. The maturity composition of government debt affects the yield curve and hence the 
financing conditions of the private sector, with possible crowding out effects (Bloch and Fall, 2015). Also, with a high share of short-term debt the government may be vulnerable to an increase in monetary policy rates. As illustrated by the recent euro area crisis, some countries (Spain, Portugal) faced sharp interest rate increases rendering the roll-over of debt very costly. Therefore, debt maturity is important for the sustainability analysis, but its effects depends on interest rate variations and strategic debt management and are not easy to gauge.

A high exposure to external holdings of government debt can generate vulnerabilities and result in a crisis, especially in emerging economies. But a high exposure also plays a role in advanced economies. The euro area countries rely more on external financing of government debt than most other countries (Figure 8). This is due to the greater financial integration of the euro area but as seen during the recent crisis, integration does not prevent sudden capital outflows or spikes in government borrowing rates that can precipitate a debt crisis.

Figure 8. General government gross debt and its external component

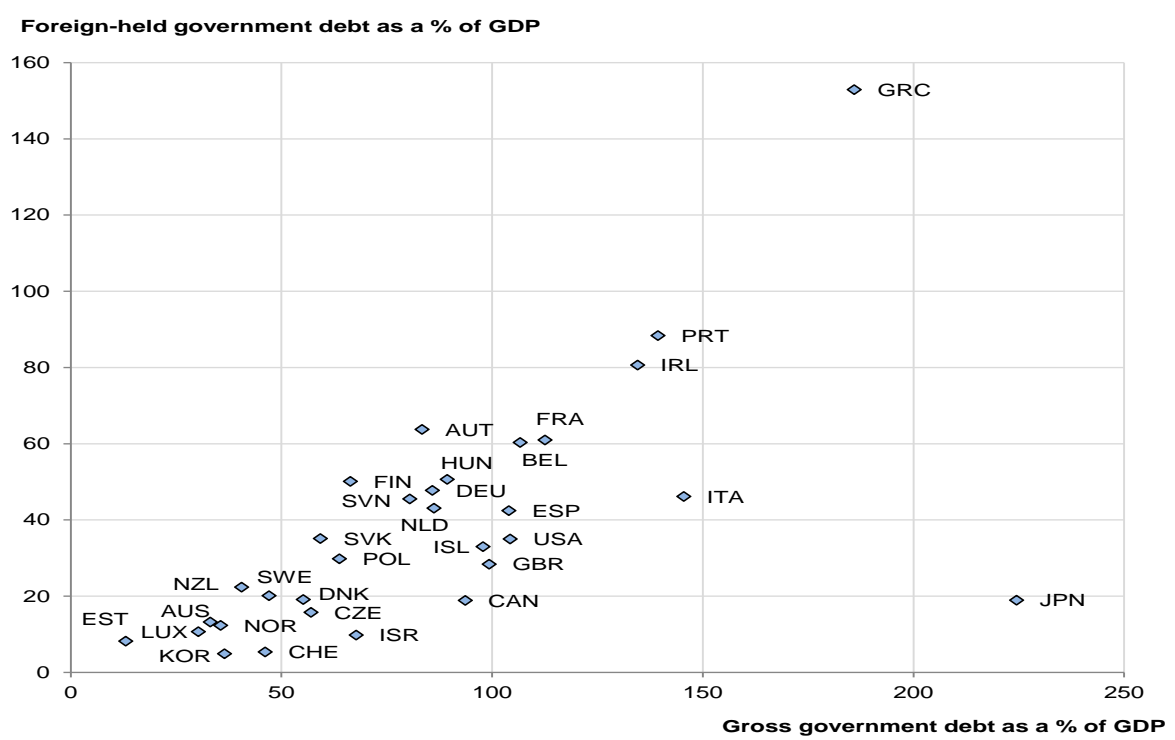

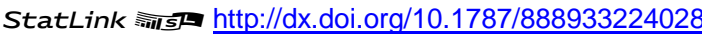
Note: External debt refers to general government debt held by external creditors (either in local currency or foreign currency). Gross government debt refers to general government gross financial liabilities.

Source: Joint External Debt Hub Database, accessed 22 September 2014; OECD Economic Outlook Database, accessed 9 October 2014.

In the case of foreign currency denomination of debt, governments are exposed to exchange rate risks, which could affect the cost of debt. In addition, the interest rate is more sensitive to the debt level if more debt is issued in foreign currency (Fall and Fournier, 2015), which can be due to the absence of a lender of last resort for foreign currency denominated debt. However, the foreign currency risk is limited for most OECD countries. Figure 9 indicates that, for the countries for which data are available, only for Hungary, Mexico, Poland and Sweden, debt denominated in foreign currency represents more than $20 \%$ of total debt. However, for countries with important assets (Sweden) or currency reserve (Hungary), the net effect of the debt composition is not straightforward. 
Figure 9. General government debt by currency denomination in selected OECD countries Fourth quarter 2013

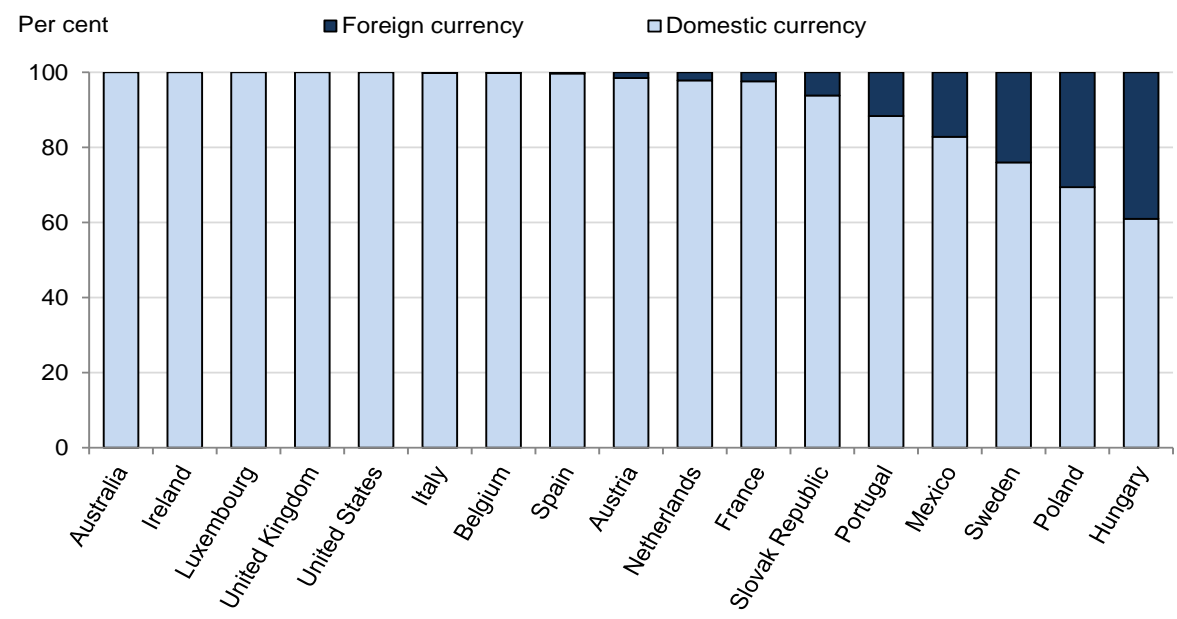

Source: IMF Quarterly Public Debt database, accessed 23 September 2014.

\subsection{Defining a prudent debt target as conveyed by stochastic simulations}

Prudent debt targets should take into account the uncertainties (macroeconomic shocks) surrounding debt developments. To minimise the risk of missing a debt target, which could undermine credibility, a prudent target for future deficit developments needs to be set. A stochastic debt analysis is developed to quantify the uncertainties surrounding the development of the main macroeconomic variables and therefore debt dynamics and this uncertainty around debt dynamics is used to define a prudent debt target (Box 3). 


\section{Box 3. Simulating the effect of shocks on public debt}

A set of seven equations is used to simulate jointly six variables and public debt dynamics. The six variables are the growth rate $g_{i t}$ of country $i$ at year $t$, the inflation rate measured by the GDP deflator $\pi_{i t}$, the overnight nominal interest rate $r_{i t}^{S}$, the long-term nominal interest rate $r_{i t}^{l}$, the primary balance $P B_{i t}$, and the structural primary balance $P B_{i t}^{\text {st }}$.

The framework includes three deterministic equations and four estimated stochastic equations, which provide the main coefficients for the simulations. The first deterministic equation is the fiscal reaction function, reflecting past behaviour of the government, as estimated in the baseline estimate of Fall and Fournier (2015). The debt accumulation dynamic is calculated with an equation that takes into account the share of debt that needs to be rolled over each year. The structural balance is defined as the primary balance minus about 0.4 times the output gap, consistent with the estimates of the impact of the business cycle on the primary balance reported in Sorbe (2012). Four estimated stochastic equations capture short-term shocks on growth, inflation, monetary policy and on long-term interest rates:

(1) $g_{i t}=\beta_{1,1} G A P_{i t-1}+\beta_{1,2}\left(r_{i t-1}^{l}-\pi_{i t-1}\right)+\beta_{1,3} \Delta P B_{i t}^{s t}+\beta_{1,4} \Delta P B_{i t}^{s t} 1_{t \geq 2009}+\beta_{1,5} \Delta P B_{i t}^{s t} 1_{t \geq 2009}+\beta_{1,6} e m u_{i t} 1_{t \geq 2009}+$ $\beta_{1,7} \Delta P B_{i t}^{s t} G A P_{i t-1}+\beta_{1,8} G A P_{i t-1} 1_{t \geq 2009}+u_{1, i}+\alpha_{1, t}+\varepsilon_{1, i t}$

(2) $\pi_{\mathrm{it}}=\beta_{2,1} \pi_{\mathrm{it}-1}+\beta_{2,2} \pi_{\mathrm{it}-2}+\beta_{2,3} \pi_{\mathrm{it}-3}+\beta_{2,4} \mathrm{GAP}_{\mathrm{it}-1}+\mathrm{u}_{2, \mathrm{i}}+\alpha_{2, \mathrm{t}}+\varepsilon_{2, \mathrm{it}}$

(3) $r_{i t}^{s}=\beta_{3,1} G A P_{i t-1}+\beta_{3,2}\left(\pi_{i t-1}-\pi_{t a r}\right)+u_{3, i}+\alpha_{3, t}+\varepsilon_{3, i t}$

(4) $r_{i t}^{l}=\beta_{4,1} r_{i t}^{S}+\beta_{4,2} g_{i t-1}+\beta_{4,3} \pi_{i t-1}^{c}+\beta_{4,4} D_{i t-1}+\beta_{3,5} e m u_{i t} D_{i t-1}+u_{4, i}+\varepsilon_{4, i t}$

where $e m u_{i t}$ is a dummy equal to one for the countries that are a member of the euro area, $\pi_{t a r}$ is the inflation target of the central bank assumed to be equal to two, and $\pi_{i t}^{c}$ denotes core inflation. $u_{i}$ and $\alpha_{t}$ are country and year fixed effects, $\varepsilon_{1, i t}, \varepsilon_{3, i t}$ and $\varepsilon_{4, i t}$ follow an $\operatorname{AR}(1)$ process and $\varepsilon_{2, i t}$ is a white noise error term.

Country-specific residuals of each of these equations are combined with output gap revisions and the time fixed effect of the first equation to capture four country specific short-term shocks, a country-specific potential output shock and a common growth shock. Shocks are jointly-drawn from the estimated co-variance of the residuals of these equations.

The simulations are run with gross debt. The mechanisms at work are the same if one replaces gross by net debt. The level of debt is modified substantially for those governments with large financial assets and hence the primary balance needed to keep debt at a prudent level is lower (see Fall and Fournier, 2015 for an example of net debt dynamics). However, the simulations with net debt do not take into account the uncertainties surrounding financial asset valuation changes.

Countries differ in terms of initial positions, the size of shocks, long-term growth potential, and heterogeneous structural features are captured by country-specific fixed effects. Two specific features capture the specificities of the euro area. First, the short-term interest rate is set jointly, based on the average output gap and average inflation. Second, the long-term interest rate reacts more to public debt in the euro area. This second feature reflects the observed market behaviour and captures a different belief on the capacity of the central bank to act as a lender of last resort and the higher risk of debt restructuring when devaluation is not possible.

Given the high level of indebtedness, many OECD countries have to pursue fiscal consolidation policies at the same time. The associated negative cross-country spillover effects can be important during the transition toward higher primary balance levels (Mendoza et al., 2014), but are not included in this exercise.

The stochastic simulations can be used to produce fan charts for future debt developments. Fall and Fournier (2015) show such fan charts for the United States. They can also be used to assess the risk of hitting a debt threshold and calculate the cushion that is needed so that adverse macroeconomic shocks do not push debt beyond the level, where adverse effects of debt on economic activity set in. In practice, this can be achieved by keeping the probability that debt goes above this threshold level sufficiently low. In the present framework, the probability of debt to go above $85 \%$ for non-euro area OECD countries and $65 \%$ for euro area countries is calculated. The prudent debt target is the median debt by 2040 such that there is less than a $25 \%$ risk to go beyond the debt threshold ( $85 \%$ or $65 \%$ debt ratio) and the corresponding fiscal deficit trajectory is calculated (see also Guillemette, 2010). Larger uncertainties in a 
country are associated with a lower prudent target. As illustrated in Figure 10 (Panel A), the prudent debt level ranges from about 35\% in Greece and Ireland to about $75 \%$ in the United Kingdom and the United States. Differences reflect the different exposure of countries to shocks and their capacity at absorbing them as estimated on the basis of their history of adjusting the primary balance.

Reaching the prudent debt target by 2040 would require a primary surplus in nineteen OECD countries (Figure 10, Panel B). Greece and Japan would need to make the largest effort (an average annual primary surplus of about $5 \%$ and $6 \%$ of GDP, respectively). The high surplus required for Japan is mainly due to the high starting point of the debt ratio. For Greece, on top of the high starting point, the required surplus is high because large uncertainties make the prudent debt level lower.

Figure 10. Public debt ranges under a prudent scenario

Panel A. Prudent debt levels

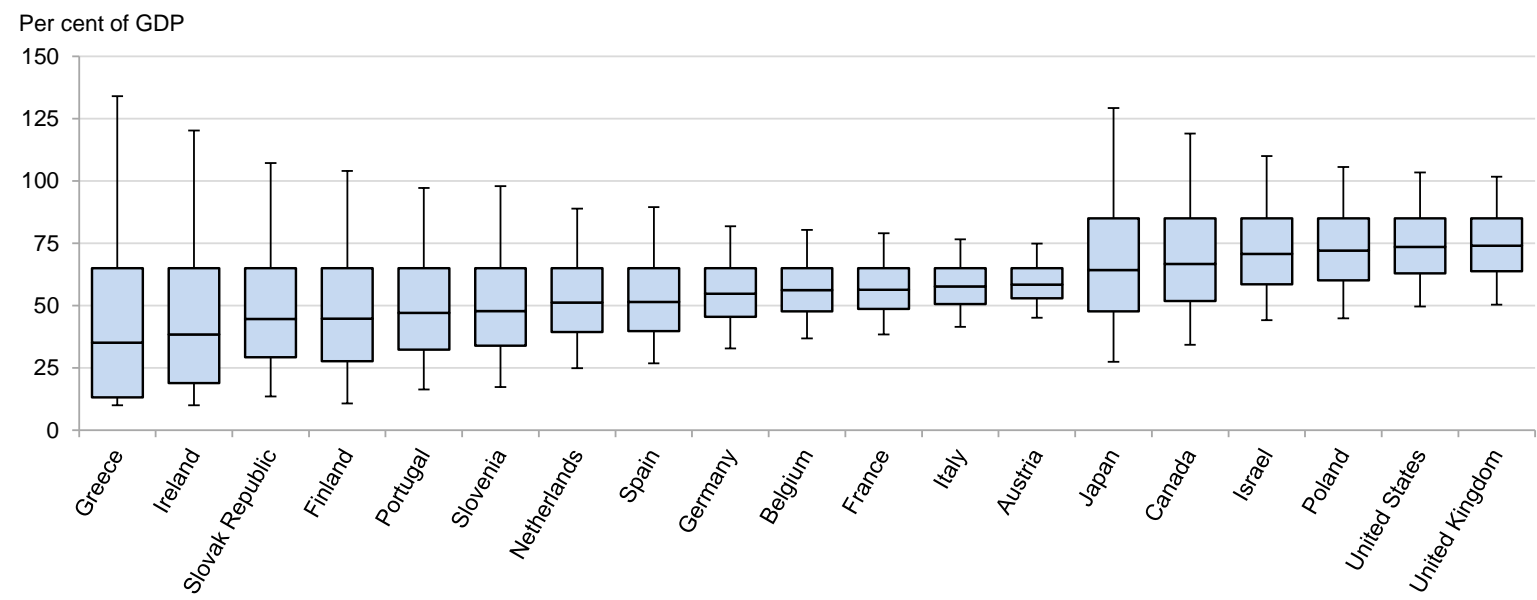

Panel B. Average annual primary balance between 2014 and 2040

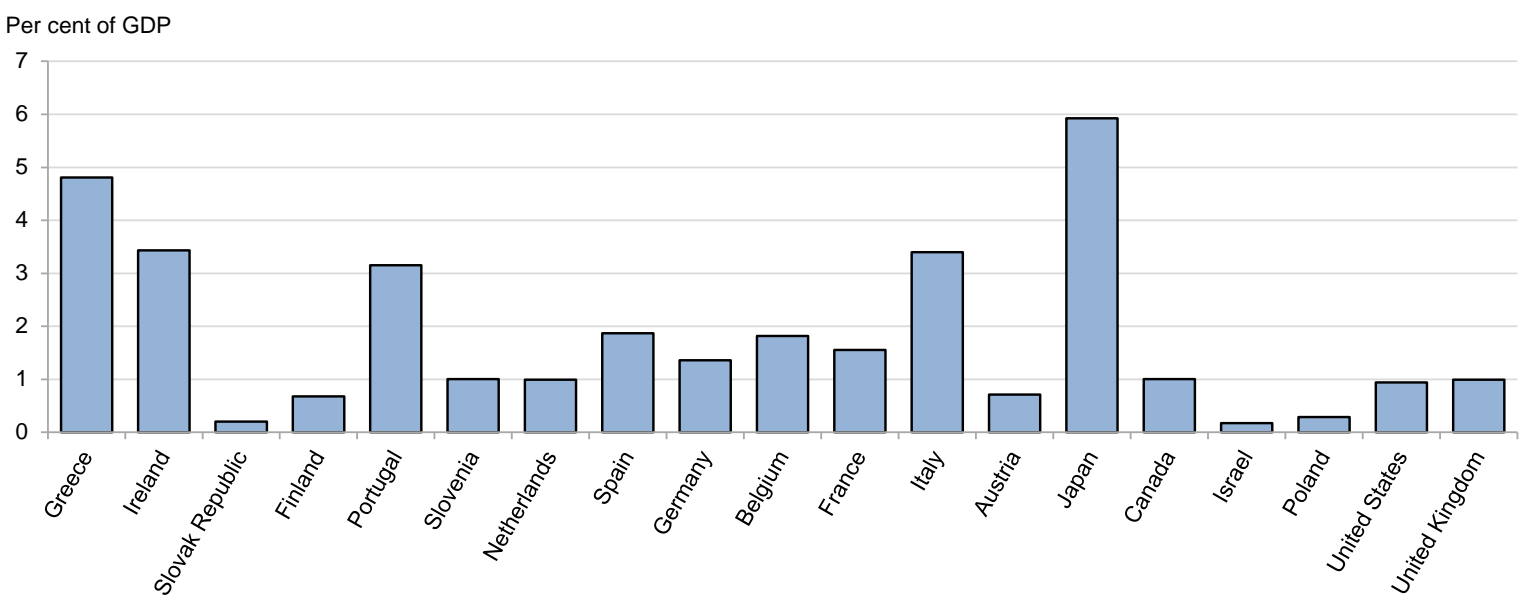

StatLink *ils http://dx.doi.org/10.1787/888933224043 Note: The thick horizontal lines show the median debt level, boxes show the interquartile range, and extreme values are the $5^{\text {th }}$ and the $95^{\text {th }}$ percentiles. Only those countries that need to generate a primary surplus are shown.

Source: OECD calculations.

A variant with larger shocks (standard deviation $50 \%$ higher than estimated in the past) results for all countries in a corresponding increase in the likelihood of recessions and of uncertainties surrounding the 
debt trajectories (Fall and Fournier, 2015). However, the larger shock variant does not imply any substantial additional consolidation effort to reach the prudent debt level.

On the other hand, if the stringency of the tolerance probability is increased from $25 \%$ to $10 \%$, for instance, the prudent debt target diminishes for all countries and consolidation needs rise (Figure 11, Panel A). The decrease of the prudent debt target is higher for countries with a bigger shock variance (this is the case for Greece and Ireland, for example). Moreover, the prudent debt target is an increasing function of the tolerance (probability) level. Figure 11, Panel B shows this relationship between the tolerance level and the prudent debt target taking the United States as an example.

Figure 11. Sensitivity of prudent debt targets to the confidence level

Panel A. Prudent debt targets by country

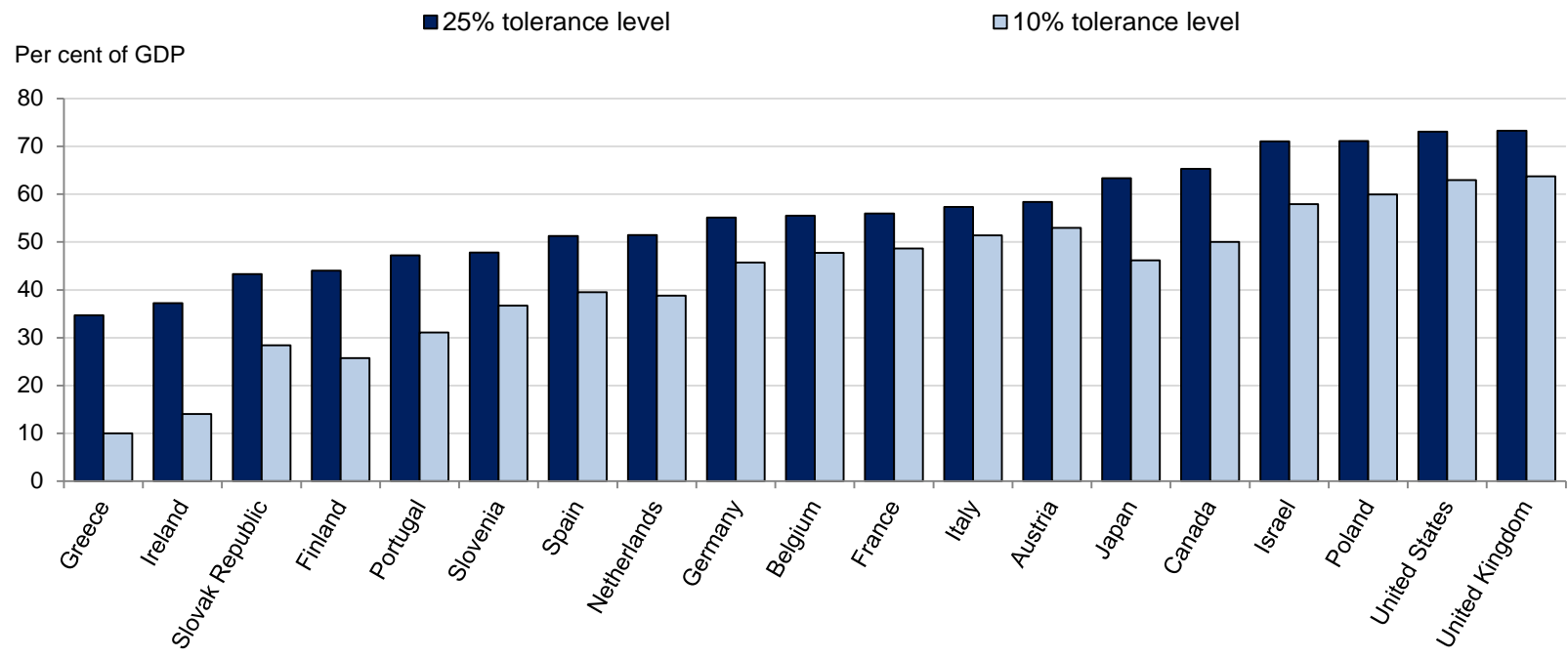

Panel B. Sensitivity of the prudent debt target to various tolerance levels (US example)

Per cent of GDP

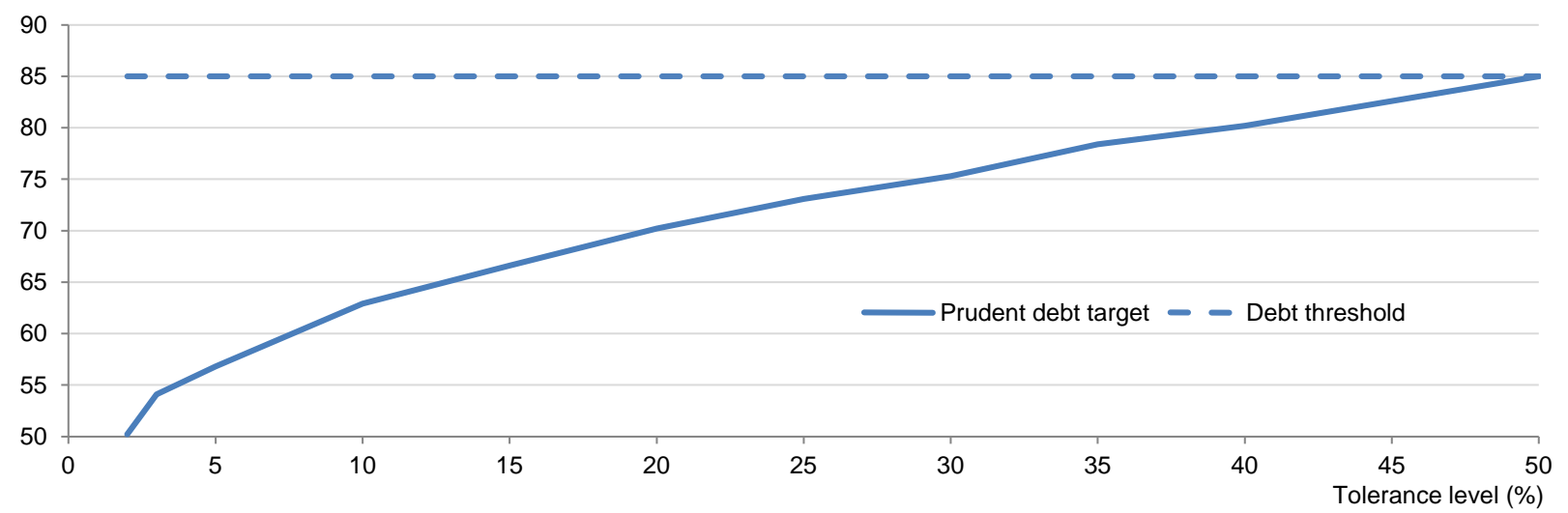

StatLink तitsh http://dx.doi.org/10.1787/888933224057 Note: This figure shows the sensitivity of the prudent debt level depicted in Figure 10, Panel A to a change of the tolerance level. Source: OECD calculations.

The stochastic simulations can only illustrate fiscal risks and their potential size. Future shocks will be different from past ones and fiscal behaviour is time dependent. Also the shocks taken into account are limited to some macroeconomic shocks and other country-specificities will also need to be taken into account, when setting the prudent debt target. For instance, the OECD countries with a high share of their debt denominated in foreign currency should take into account the accompanying exchange rate risk in determining their prudent debt target. 


\section{Designing fiscal frameworks}

\subsection{Justifications, objectives and composition of the fiscal framework}

In all countries, there is a set of rules and institutions that shape fiscal policy making. They comprise the institutions, arrangements and procedures that govern the planning and implementation of budgetary policies.

In most advanced countries, debt ratios have been trending up since the late 1970s, illustrating the lack of fiscal discipline and the inability of governments to commit to sustainable public finances. Indeed, debt breaks the link between taxation and spending, tempting governments to shift the fiscal burden to future generations. A large literature identifies reasons, why such a deficit bias exists (see Persson and Tabellini, 2000; Wyplosz, 2013; Calmfors and Wren-Lewis, 2011): ${ }^{6}$

- Informational problems: The electorate may lack information on fiscal positions. This ignorance may allow the government to increase its chances of re-election, creating a political business cycle. As there is no similar incentive to raise taxes or cut spending after elections, this will lead to deficit bias.

- Electoral competition: Competition between parties will drive up debt (Alesina and Tabellini, 1990; Persson and Svensson, 1989). Governments will follow the preferences of their electorate over public goods or the size of government and will use increasing debt as a strategic tool to prevent future governments from implementing the programmes they prefer.

- Common-pool theory: Different groups lobby for public spending catering to their specific interests with insufficient regard to the full budgetary costs now as well as in the future (Krogstrup and Wyplosz, 2010).

- Intergenerational equity: Deadweight losses due to higher taxation to service the higher debt level would fall on the future generations. Moreover, lower income people, which tend to hold only a small amount of assets, including government bonds, would not benefit from interest payments, but would have to pay taxes to service the higher debt.

- Pro-cyclicality: Deficit bias results in large part from a failure to exercise budget discipline in good times (Manasse, 2006; Tornell and Lane, 1999).

The major objectives of the fiscal framework are twofold: it should underpin fiscal discipline in reaching the prudent debt target and allow for short-run flexibility of fiscal policy to react to cyclical developments and shocks. A rule serves as a commitment tool to increase the cost of deviations and to anchor expectations about future fiscal developments. Some discretion remains, however, essential to guarantee that fiscal policy can react to sizeable shocks.

The fiscal framework should make it more likely that countries with high debt will follow a path towards a more prudent level and that countries close to the prudent debt target will seek to stay there. Five components of the fiscal framework are considered: a debt target, a fiscal rule, fiscal councils, budgetary processes and medium-term budgeting.

\subsection{Setting a debt target}

In designing a fiscal framework, the starting point is to define the targets and instruments. A debt target can be effective in anchoring expectations about future fiscal policy. The prudent debt target serves as the reference point to define numerical fiscal rules, in particular, for countries with high debt that have to converge to a lower prudent debt ratio.

6. These categories are based on Calmfors and Wren-Lewis (2011). 
A debt target is better than a debt limit. The experience of the EU framework is that, in the absence of a debt target, debt drifted up towards the $60 \%$ of GDP limit or even beyond, leaving no room to absorb the sizeable fiscal shock of the recent crisis without breaching the limit.

\subsection{Fiscal rules}

\section{Justifications, objectives, types and conditions for the effectiveness of fiscal rules}

The debt target needs to be complemented by fiscal rules that allow for counter-cyclical policies and escape clauses in the case of large shocks. Many countries have adopted fiscal rules that constrain their government's policies and underpin fiscal discipline. However, they can also lead to sub-optimal policies. Indeed, there is a trade-off between commitment and discretion: on the one side, rules provide valuable commitment that can limit interest rate risk premiums by curbing policy makers spending bias and excessive deficits; on the other hand, a strict rule leads to costs in terms of lost flexibility as rules are necessarily incomplete, and some discretion may be optimal. Since Kydland and Prescott's (1977) seminal contribution, it is known that time-inconsistency often prevails because short-term considerations push policymakers to deviate from ex-ante optimal strategies. Moreover, Halac and Yared (2014) show that, when shocks are persistent, the ex-ante optimal rule is not sequentially optimal, as it provides incentives for governments to over-accumulate debt. Also, fiscal rules may limit the capacity of governments to pursue macroeconomic stabilisation policies (see also Wyplosz (2013), for a discussion).

But in practice, discretion may undermine discipline. As noticed by Kopits (2011a), discretionary fiscal policy did often not fulfil the role of macroeconomic stabilisation. There is evidence that the conduct of fiscal policy was more often pro-cyclical than not (Taylor, 2000; Auerbach, 2002). Also Égert (2010) finds that fiscal policy in countries with high public debt and high government deficits tends to be pro-cyclical.

Different analyses provide insights in the conditions of the effectiveness of fiscal rules. Bohn and Inman (1996), studying the effectiveness of fiscal rules among the US States provides strong evidence that the form of a balanced-budget rule matters. They find that more stringent balance rules with outside enforcement have a positive impact on budget balances. Poterba (1994) finds that the no-carryover rule is associated with a more rapid reduction of the budget deficit, mainly through lower spending, and not higher taxes. More recently, Clemens and Miran (2013) find that during times of fiscal stress, states with strict rules enact relatively large budget cuts in order to quickly narrow deficits.

Alesina and Bayoumi (1996) find that fiscal policy restrictions have little effect on output volatility in US states, because fiscal policy restrictions have two opposite effects: 1) strict fiscal rules lead to lower policy volatility (i.e. less discretion in conducting fiscal policy; 2) fiscal restrictions reduce the responsiveness of fiscal policy to output shocks and decrease the persistence of spending fluctuations which might amplify the business cycle. Overall, these effects cancel each other. On the other hand, Fàtas and Mihov's (2006) results support the notion that the effects of fiscal constraints dominate and therefore can reduce macroeconomic volatility. They show that fiscal policy is a significant source of business cycle volatility for US States, and, as a result, constraints on politicians lead to less volatile economic fluctuations. At the country level, Fatàs and Mihov (2003) showed that constraints on fiscal policy reduce the volatility of the business cycle.

It is often argued that public investment that fosters long-run growth should be excluded from fiscal targets. However, drawing the line for public investment that matters for long-run growth is not straightforward, as not only public physical investment, but also spending on education or research and development have a positive effect on growth. Moreover, if public investment is debt financed, it is better to take it into account as debt is created and the positive effects on growth are reaped in the short run (demand effect) and in the long-run (supply effect with spill-overs to the private sector).

Table 4 reviews the different rules and their likely effects on fiscal discipline and stabilisation policies. They are also subject to different measurement uncertainties and side-effects of fiscal policy. These factors determine their suitability as fiscal rules in a sound fiscal framework. 
Table 4. Strengths and weaknesses of existing fiscal rules

\begin{tabular}{|c|c|c|c|}
\hline & Promotion of fiscal discipline & Impact on stabilisation policies & Risks and side effects \\
\hline $\begin{array}{l}\text { Budget } \\
\text { balance } \\
\text { rules }\end{array}$ & $\begin{array}{l}\text { Numerical budget balance rules seem to } \\
\text { have a positive impact (that is higher } \\
\text { surpluses or lower deficits) on } \\
\text { budgetary outcomes (Debrun, X., et al. } \\
\text { (2008), "Tied to the Mast? The Role of } \\
\text { National Fiscal Rules in the European } \\
\text { Union", Economic Policy, No. 54, } \\
\text { pp. 298-362). Numerical budget } \\
\text { balance rules give a concrete } \\
\text { benchmark upon which to judge the } \\
\text { fiscal stance (European Commission } \\
\text { (2011), "Public Finances in EMU - } \\
2011 ", \text { European Economy, No. 4/2011. } \\
\text { Brussels: European Commission). }\end{array}$ & $\begin{array}{l}\text { Strict budget balance rules fail to } \\
\text { provide enough flexibility to pursue } \\
\text { a counter-cyclical fiscal policy. } \\
\text { They tend to induce pro-cyclicality } \\
\text { that can be reinforced by weak } \\
\text { coordination between different } \\
\text { government levels }\end{array}$ & $\begin{array}{l}\text { They can induce governments } \\
\text { under fiscal consolidation pressures } \\
\text { to rely excessively on cuts to } \\
\text { growth-enhancing, but politically } \\
\text { less sensitive, expenditure such as } \\
\text { public investment. To counter such } \\
\text { adverse effects, it is often proposed } \\
\text { to exclude investment and focus on } \\
\text { the current balance (Golden rule). }\end{array}$ \\
\hline $\begin{array}{l}\text { Structural } \\
\text { balance } \\
\text { rules }\end{array}$ & $\begin{array}{l}\text { In principle, structural balance rules } \\
\text { underpin fiscal discipline. As they set a } \\
\text { target for the evolution of a core } \\
\text { variable, which is purged of cyclical } \\
\text { effects, they define the space for } \\
\text { discretionary policy. }\end{array}$ & $\begin{array}{l}\text { Structural or cyclically-adjusted } \\
\text { balance rules provide some } \\
\text { flexibility as they allow the } \\
\text { automatic stabilisers to play in full. } \\
\text { Indeed, they are less binding than } \\
\text { budget balance rules as they } \\
\text { account for the effects of the cycle. }\end{array}$ & $\begin{array}{l}\text { These rules are vulnerable to } \\
\text { uncertainties about the } \\
\text { measurement of the output gap, } \\
\text { which renders real-time monitoring } \\
\text { difficult. A structural deficit rule can } \\
\text { be misleading if the output gap and } \\
\text { potential growth estimates are too } \\
\text { optimistic or too pessimistic. }\end{array}$ \\
\hline $\begin{array}{l}\text { Expenditure } \\
\text { rules }\end{array}$ & $\begin{array}{l}\text { Expenditure rules enhance fiscal } \\
\text { discipline thanks to better accountability } \\
\text { and higher transparency in the budget } \\
\text { process. They allow for better control of } \\
\text { primary spending by the government. } \\
\text { They played an important role in } \\
\text { effective fiscal frameworks in the } \\
\text { Netherlands, Denmark, Sweden, and } \\
\text { Finland (European Commission, 2010, } \\
\text { "Public Finances in EMU - 2010", } \\
\text { European Economy, No. 4/2010. } \\
\text { Brussels: European Commission). }\end{array}$ & $\begin{array}{l}\text { A well-designed spending rule } \\
\text { should not prevent the automatic } \\
\text { stabilisers from operating. Also, } \\
\text { spending rules can limit pro- } \\
\text { cyclical spending in the presence } \\
\text { of revenue windfalls in good times. }\end{array}$ & $\begin{array}{l}\text { Spending rules have the same } \\
\text { drawbacks as budget balance rules } \\
\text { regarding the quality of spending or } \\
\text { cuts, in particular in difficult times. } \\
\text { They also can induce the use of tax } \\
\text { expenditure for various policy } \\
\text { objectives for which direct spending } \\
\text { might be better suited. }\end{array}$ \\
\hline $\begin{array}{l}\text { Revenue } \\
\text { rules }\end{array}$ & $\begin{array}{l}\text { Revenue rules can be useful in limiting } \\
\text { the tax burden. The impact on deficit } \\
\text { limitation is a by-product as limitations } \\
\text { on revenues should constrain } \\
\text { governments from excessive spending. } \\
\text { It also serves to avoid pro-cyclical } \\
\text { policies, in particular, when the use of } \\
\text { higher-than-expected revenues is } \\
\text { defined ex ante in the budget law. }\end{array}$ & $\begin{array}{l}\text { Revenue rules fail to } \\
\text { accommodate macroeconomic } \\
\text { stabilisation. However, they can } \\
\text { help to limit the spending of } \\
\text { revenue windfalls in good times. }\end{array}$ & $\begin{array}{l}\text { Revenue rules can lead to } \\
\text { additional spending, as it is difficult } \\
\text { to establish the cyclical component } \\
\text { of revenues. For instance, in some } \\
\text { countries prolonged booms in } \\
\text { property and asset prices led to } \\
\text { additional public expenditure, and } \\
\text { therefore increased the risk of pro- } \\
\text { cyclicality and unsustainable fiscal } \\
\text { policies. }\end{array}$ \\
\hline
\end{tabular}


As shown in Table 5, most of the existing rules are numerical rules that set a clear target or constrain government policy options. Debt rules are present in many countries and are sometimes complemented by expenditure or budget balance rules. Seven OECD countries have a debt target, while five have a debt limit, and 21 have the supranational EU debt limit.

European Union members have supranational rules including a debt limit of $60 \%$ of GDP, a deficit limit of $3 \%$ of GDP, and an expenditure rule: the annual growth of primary expenditure - excluding unemployment benefits and subtracting discretionary revenue increases - should not exceed long-term nominal GDP growth.

Table 5. Synthesis of existing fiscal rules

\begin{tabular}{|c|c|c|c|c|}
\hline $\begin{array}{l}\text { Budget balance } \\
\text { rule }\end{array}$ & $\begin{array}{c}\text { Structural balance } \\
\text { rule }\end{array}$ & Debt rule & Expenditure rule & Revenue rule \\
\hline $\begin{array}{l}\text { Budget deficit target } \\
\text { (in } \% \text { of GDP) }\end{array}$ & $\begin{array}{l}\text { Structural deficit } \\
\text { target in } \% \text { of GDP }\end{array}$ & $\begin{array}{l}\text { Debt-to-GDP }<= \\
\text { X\% of GDP (where } \\
X \text { is either } 40 \% \text {, } \\
50 \% \text { and } 60 \% \text { of } \\
\text { GDP) }\end{array}$ & $\begin{array}{l}\text { Expenditure = X\% of GDP } \\
\text { Discretionary spending caps } \\
\text { and automatic spending cuts } \\
\text { (the so-called sequester) }\end{array}$ & $\begin{array}{l}\text { Revenue growth = } \\
\text { GDP growth }\end{array}$ \\
\hline \multirow[t]{6}{*}{$\begin{array}{l}\text { Primary surplus } \\
\text { target }\end{array}$} & $\begin{array}{l}\text { Structural budget is } \\
\text { in balance }\end{array}$ & Debt-to-GDP = 0 & $\begin{array}{l}\text { Spending growth }<=x \% \text { or a } \\
\text { target in nominal or real terms }\end{array}$ & $\begin{array}{l}\text { Multi-year revenue } \\
\text { path }\end{array}$ \\
\hline & $\begin{array}{l}\text { Structural surplus = } \\
\text { X\% of potential GDP }\end{array}$ & & $\begin{array}{l}\text { Spending growth = growth rate } \\
\text { of GDP }\end{array}$ & $\begin{array}{l}\text { Revenue windfall } \\
\text { rule }\end{array}$ \\
\hline & $\begin{array}{l}\text { Structural annual } \\
\text { fiscal effort }>= \\
X \% \text { of GDP }\end{array}$ & & $\begin{array}{l}\text { Spending growth = rate of } \\
\text { inflation + population growth }\end{array}$ & \\
\hline & & & $\begin{array}{l}\text { Spending growth }<=\text { potential } \\
\text { growth }\end{array}$ & \\
\hline & & & $\begin{array}{l}\text { Spending growth }<=x \% \text { or a } \\
\text { target }+ \text { a second condition or } \\
\text { escape clause }\end{array}$ & \\
\hline & & & $\begin{array}{l}\text { Non-cyclical primary spending } \\
\text { (real) = max } \times \%\end{array}$ & \\
\hline
\end{tabular}

Source: Synthesis based on IMF (2012), "Fiscal Rules at a Glance: Country Details from a New Dataset", IMF Working Paper, WP/12/273.

New estimations suggest that fiscal rules have an impact on fiscal performance (Table 6). The indicators of fiscal performance are the primary balance, government spending, government receipts and the cyclically-adjusted primary balance. The impact of different fiscal rules on these variables is estimated with control variables of the main determinants of fiscal performance. An increase in government gross debt is positively correlated with improvements in the primary balance and the cyclically-adjusted primary balance, through decreasing government spending and increasing revenues. An increase of the old age dependency ratio has a negative effect on the primary balance, by increasing spending and reducing receipts.

The budget balance rule appears to have a positive and significant effect on the primary balance (Table 6, Column P2) and a negative and significant effect on spending (Table 6, Column S2). In contrast, spending rules are significant only in restraining government spending (Table 6, Column S3).

The estimations confirm that an index of the stringency of fiscal rules (sum of rules) has a positive and significant impact on the primary balance and a constraining and significant effect on government spending and receipt. These results are in line with the findings by Marneffe et al. (2011) and Debrun et al. (2013). Also, Nerlich and Reuter (2013) find that numerical fiscal rules combined with fiscal councils and mediumterm budgeting framework help to improve the primary balance for EU member states. However, the results may also reflect that disciplined countries are likely to adopt fiscal rules. 
Table 6. Estimations of the effectiveness of fiscal rules

\begin{tabular}{|c|c|c|c|c|c|c|c|c|c|c|c|c|}
\hline & \multicolumn{3}{|c|}{ Primary balance } & \multicolumn{3}{|c|}{ Spending } & \multicolumn{3}{|c|}{ Receipts } & \multicolumn{3}{|c|}{ Cyclically-adj. primary balance } \\
\hline & (P1) & (P2) & (P3) & (S1) & (S2) & (S3) & (R1) & (R2) & (R3) & (C1) & (C2) & (C3) \\
\hline \multirow[t]{2}{*}{ Lag of the dependent variable } & $0.89^{\star \star *}$ & $0.88^{\star \star \star}$ & $0.90^{\star \star *}$ & $1.02^{\star \star \star}$ & $1.02^{\star \star \star}$ & $1.03^{\star \star \star}$ & $0.88^{\star \star \star}$ & $0.89^{\star * *}$ & $0.89^{* * *}$ & $0.86^{\star \star *}$ & $0.86^{\star \star \star}$ & $0.87^{\star \star *}$ \\
\hline & {$[0.028]$} & [0.031] & {$[0.028]$} & {$[0.016]$} & {$[0.016]$} & {$[0.017]$} & {$[0.026]$} & {$[0.026]$} & [0.025] & {$[0.028]$} & {$[0.028]$} & {$[0.028]$} \\
\hline \multirow[t]{2}{*}{ GG gross debt (t-1) } & $0.022^{\star \star \star}$ & $0.021^{\star \star *}$ & $0.023^{\star * *}$ & $-0.0085^{\star \star}$ & $-0.0080^{* *}$ & $-0.0093^{* * *}$ & $0.0138^{\star \star \star}$ & $0.0132^{\star \star \star}$ & $0.0130 * \star \star$ & $0.0228^{\star * \star}$ & $0.0225^{\star \star \star}$ & $0.0239 * * *$ \\
\hline & [0.0048] & [0.0049] & [0.0049] & {$[0.0034]$} & {$[0.0034]$} & {$[0.0034]$} & {$[0.0031]$} & [0.0033] & {$[0.0030]$} & {$[0.0041]$} & [0.0043] & [0.0041] \\
\hline \multirow[t]{2}{*}{ Output gap (t-1) } & 0.0022 & 0.0088 & 0.0093 & $0.108^{\star \star *}$ & $0.101^{\star \star *}$ & $0.106^{\star \star \star}$ & $0.060^{\star * *}$ & $0.062^{\star \star *}$ & $0.062^{\star \star \star}$ & -0.012 & -0.0097 & -0.003 \\
\hline & {$[0.028]$} & {$[0.027]$} & {$[0.027]$} & {$[0.023]$} & {$[0.024]$} & {$[0.023]$} & {$[0.021]$} & {$[0.020]$} & {$[0.020]$} & {$[0.025]$} & {$[0.025]$} & {$[0.024]$} \\
\hline \multirow[t]{2}{*}{ Openness * Terms of trade } & $0.0002^{\star \star \star}$ & $0.0002^{\star \star \star}$ & $0.0002^{\star \star \star}$ & $-0.0002^{\star \star *}$ & $-0.0002^{\star * *}$ & $-0.0002^{\star * *}$ & -0.0001 & 0 & -0.0001 & $0.0001^{* \star *}$ & $0.0001^{* \star *}$ & $0.0001^{\star * \star}$ \\
\hline & {$[0.0001]$} & {$[0.0001]$} & {$[0.0001]$} & {$[0.0000]$} & [0.0000] & {$[0.0000]$} & [0.0000] & [0.0000] & [0.0000] & [0.0001] & [0.0001] & [0.0001] \\
\hline \multirow[t]{2}{*}{ Dependency ratio } & $-0.0011^{\star \star}$ & $-0.0012^{\star \star}$ & $-0.0014^{\star \star \star}$ & 0.0002 & 0.0002 & 0.0004 & $-0.0006^{*}$ & -0.0005 & -0.0005 & $-0.0013^{\star * *}$ & $-0.0013^{\star * *}$ & $-0.0015^{\star \star *}$ \\
\hline & {$[0.0005]$} & {$[0.0005]$} & {$[0.0005]$} & [0.0003] & [0.0003] & [0.0003] & [0.0003] & [0.0003] & [0.0003] & [0.0004] & [0.0004] & [0.0004] \\
\hline \multirow[t]{2}{*}{ Fiscal rule stringency index } & $0.24^{\star \star \star}$ & & & $-0.23^{\star \star *}$ & & & $-0.12^{*}$ & & & 0.11 & & \\
\hline & [0.079] & & & {$[0.062]$} & & & {$[0.071]$} & & & {$[0.076]$} & & \\
\hline \multirow[t]{2}{*}{ Fiscal council dummy } & 0.61 & 0.76 & 0.24 & & $-0.77^{\star \star}$ & -0.23 & & -0.42 & -0.14 & 0.14 & 0.14 & 0.032 \\
\hline & {$[0.38]$} & {$[0.47]$} & {$[0.29]$} & & {$[0.34]$} & {$[0.25]$} & & {$[0.41]$} & {$[0.25]$} & {$[0.35]$} & {$[0.44]$} & {$[0.26]$} \\
\hline \multirow[t]{2}{*}{ Fiscal rule index * Fiscal council } & -0.17 & & & & & & & & & -0.025 & & \\
\hline & [0.106] & & & & & & & & & {$[0.116]$} & & \\
\hline \multirow[t]{2}{*}{ Fiscal council safeguard on budget } & & & & -0.54 & & & $-0.89^{\star *}$ & & & & & \\
\hline & & & & [0.38] & & & {$[0.42]$} & & & & & \\
\hline \multirow[t]{2}{*}{$\begin{array}{l}\text { Fiscal rule index * Fiscal council } \\
\text { safeguard on budget }\end{array}$} & & & & $0.24^{\star \star}$ & & & $0.33^{\star \star \star}$ & & & & & \\
\hline & & & & {$[0.106]$} & & & [0.1188] & & & & & \\
\hline \multirow[t]{2}{*}{ Fiscal budget balance rule } & & $0.55^{\star \star}$ & & & $-0.40^{* *}$ & & & -0.21 & & & 0.24 & \\
\hline & & {$[0.24]$} & & & {$[0.19]$} & & & {$[0.22]$} & & & [0.23] & \\
\hline \multirow[t]{2}{*}{$\begin{array}{l}\text { Fiscal budget balance rule * Fiscal } \\
\text { council }\end{array}$} & & -0.66 & & & $0.86^{\star \star \star}$ & & & 0.46 & & & -0.033 & \\
\hline & & [0.48] & & & {$[0.32]$} & & & [0.41] & & & [0.48] & \\
\hline \multirow[t]{2}{*}{ Fiscal expenditure rule } & & & 0.36 & & & $-0.73^{\star \star \star}$ & & & -0.33 & & & -0.045 \\
\hline & & & {$[0.23]$} & & & {$[0.20]$} & & & {$[0.22]$} & & & {$[0.19]$} \\
\hline \multirow{2}{*}{$\begin{array}{l}\text { Fiscal expenditure rule * Fiscal } \\
\text { council }\end{array}$} & & & -0.070 & & & $0.47^{\star}$ & & & 0.28 & & & 0.26 \\
\hline & & & {$[0.30]$} & & & {$[0.24]$} & & & {$[0.28]$} & & & {$[0.33]$} \\
\hline Time fixed-effects & Yes & Yes & Yes & Yes & Yes & Yes & Yes & Yes & Yes & Yes & Yes & Yes \\
\hline Country fixed-effects & Yes & Yes & Yes & Yes & Yes & Yes & Yes & Yes & Yes & Yes & Yes & Yes \\
\hline $\mathrm{N}$ & 619 & 619 & 619 & 622 & 622 & 622 & 623 & 623 & 623 & 611 & 611 & 611 \\
\hline Countries & 30 & 30 & 30 & 30 & 30 & 30 & 30 & 30 & 30 & 30 & 30 & 30 \\
\hline
\end{tabular}

Note: Standard errors are in parentheses. * significant at 10\%, ** significant at 5\%, ${ }^{* *}$ significant at $1 \%$. Dependent variables are adjusted for one-off expenditure.

Source: OECD Economic Outlook 95 and IMF fiscal council and fiscal rules dataset. 


\section{Designing fiscal rules consistent with debt targets and stabilisation objectives}

The debt trajectory is the core concern of the fiscal framework. Given the uncertainties surrounding the macroeconomic determinants of debt developments and also that these macroeconomic variables are beyond the control of the government, though they are endogenously affected by government policies, fiscal rules will target the main determinants of debt directly under government control.

Fiscal rules should have two objectives: (1) anchor fiscal policy expectations by targeting a prudent debt level and (2) allow for macroeconomic stabilisation that enhances economic growth. Fiscal stimulus to mitigate recessions increases uncertainties surrounding the debt path: there is a trade-off between these two objectives (Figure 12). Real time stimulus may stabilise the cycle, but also affects debt dynamics. The macroeconomic model, set out in Box 3 , is used to illustrate this trade-off.

Figure 12. The trade-off between counter-cyclicality and hitting the debt target Panel A. Long-term recession risks

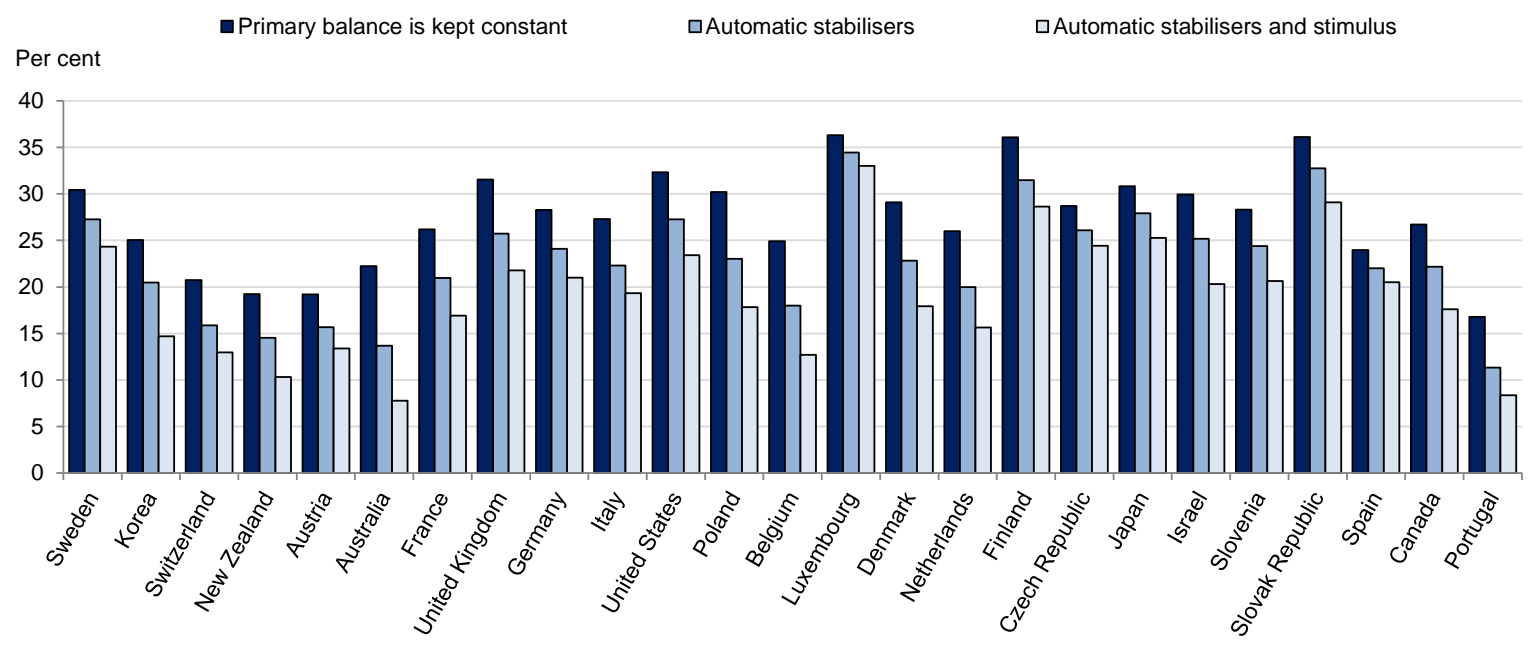

Panel B. Debt ratio uncertainties

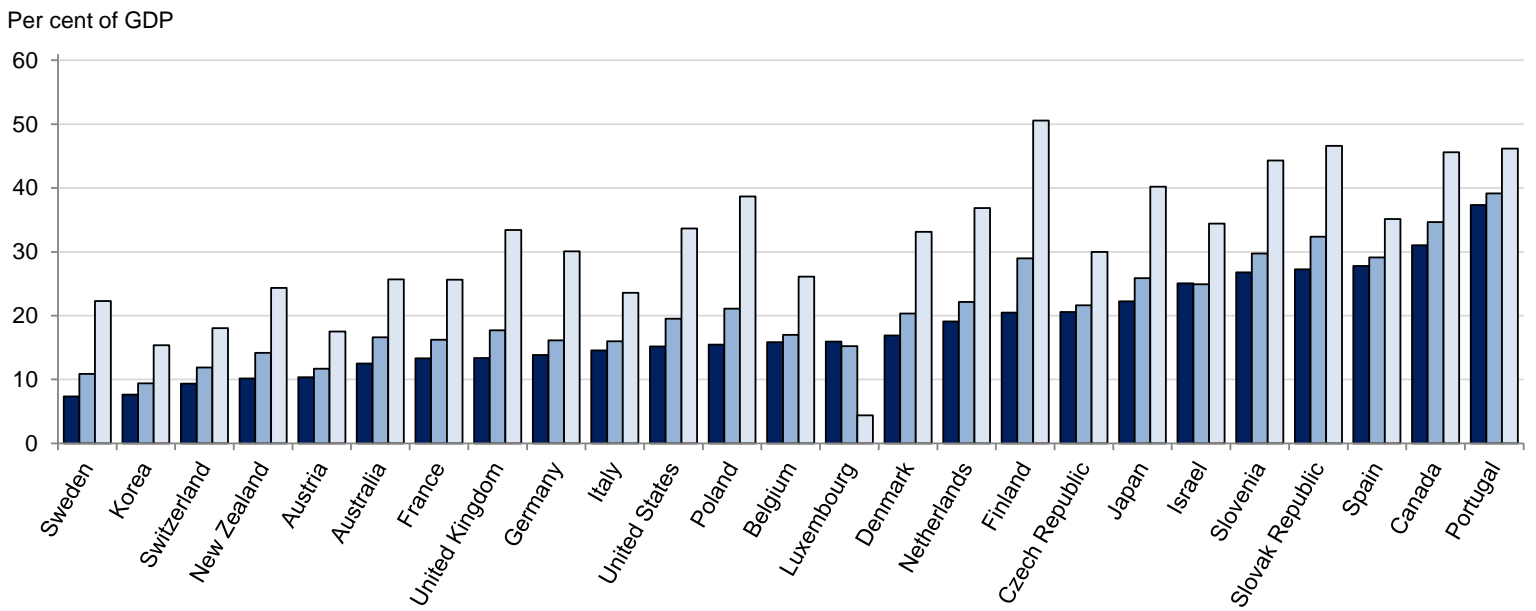

StatLink तiाs http://dx.doi.org/10.1787/888933224069 Note: The long-term recession risk is the probability of GDP per capita growth to become negative. The uncertainty surrounding the debt trajectory is assessed by the interquartile range of the debt level in 2040. The "Primary balance is kept constant" simulation is a stylised scenario in which the actual primary balance is kept constant such that the prudent debt target is reached, with no automatic stabilisers. In the scenario labelled "Automatic stabilisers", a one percentage point negative surprise in the output gap is associated with a $0.4 \%$ of GDP stimulus. In the "Automatic stabilisers and stimulus" scenario, the government is taking discretionary measures on top of automatic stabilisers in reacting to changes in the output gap.

Source: OECD calculations. 
A good fiscal rule should have two main properties:

- The fiscal rules should define a confidence interval or a band for its main variables to accommodate macroeconomic fluctuations. If the economy has a budget or structural deficit close to a fixed limit, the limit constitutes an important restriction for the stabilisation effects of both the automatic stabilisers and counter-cyclical discretionary fiscal policy in a downturn.

- A combination of rules should ensure compliance with the chosen debt trajectory. A budgetary constraint cannot only refer to the budget balance, if it is to avoid potential adverse effects on the underlying components of the budget balance (e.g. undesirable tax increases to compensate for structural problems on the expenditure side).

The rules differ in their ability to fulfil objectives of reaching a prudent debt target and of stabilisation. The structural budget balance rule combines, in principle, the capacity of satisfying the two objectives, but it has important drawbacks in terms of observability and real time assessment. Structural balance measures, despite some progress on measurement, are highly dependent on volatile and often biased estimates of the output gap and subject to frequent revisions (Hers and Suyker, 2014). For instance, for Slovakia, Klein et al. (2013) report that the structural deficit in 2010 using pre-crisis estimates of potential growth would have been nearer to $4 \%$ than $8 \%$ of GDP.

Also, structural deficits can be revised sharply in the case of a crisis as potential growth is not well measured in real time (Figure 13). In particular, the downward revision of the structural primary balance was about 7\% of GDP for Greece and about 3\% of GDP in Ireland. These revisions follow growth surprises: on average across countries, a $1 \%$ real output shock is associated with a $0.2 \%$ revision of the potential output level (Fall and Fournier, 2015).

Figure 13. The pre-crisis overestimation of structural balances

2007 structural primary balance as a per cent of potential GDP

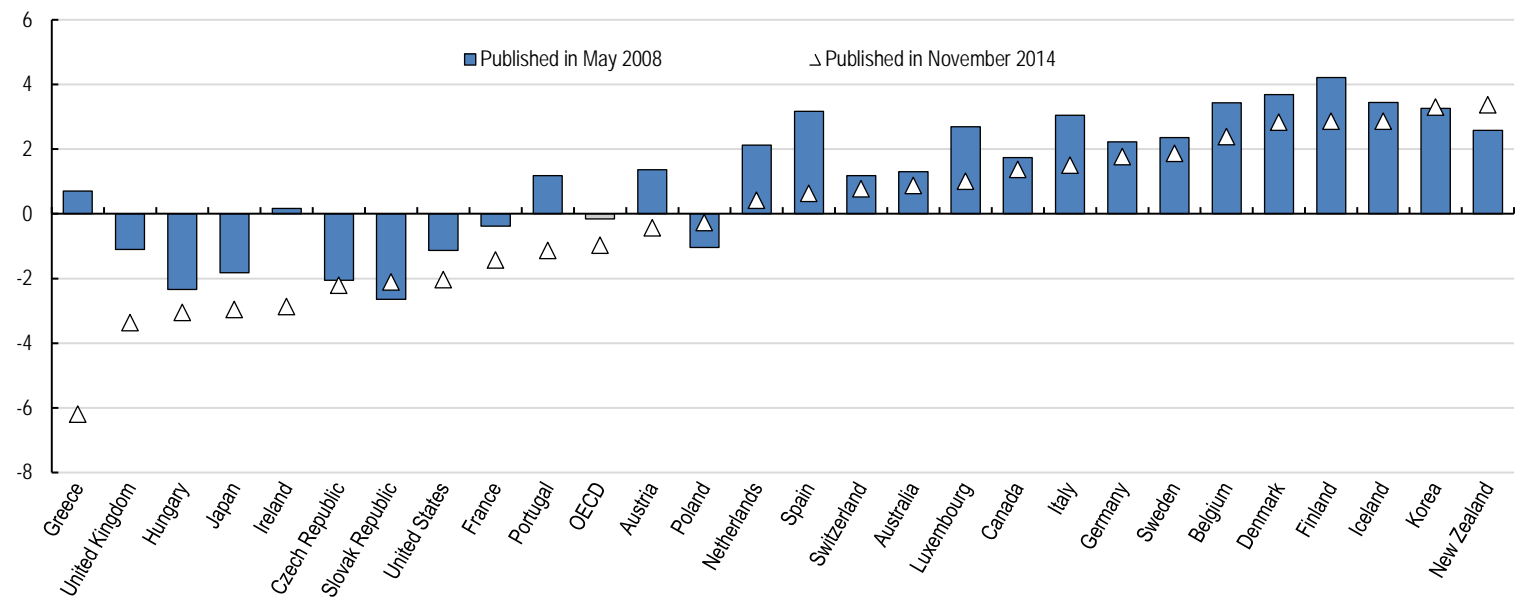

StatLink -iाlst http://dx.doi.org/10.1787/888933224071 Note: The structural primary balance published in May 2008 was calculated with the available information at that time, such as the general government accounts, the provisional GDP estimate and the potential output calculated in 2008. In practice, the difference between this publication and the latest one is mainly due to revisions in potential output, though there was also a sharp downward revision of the actual primary balance for Greece.

Source: Economic Outlook No. 83 and No. 96 databases.

Therefore, the adoption of a budget balance rule complemented by an expenditure rule could suit most countries well. As shown in Table 7, the combination of the two rules responds to the two objectives. A budget balance rule encourages hitting the debt target. And, well-designed expenditure rules appear decisive in ensuring the effectiveness of a budget balance rule (Guichard et al., 2007). Carnot (2014) shows also that a binding spending rule can promote fiscal discipline while allowing for stabilisation 
policies. The marginal benefit of adding a revenue rule is likely outweighed by its costs in terms of complexity and reduction in fiscal flexibility.

Table 7. Synthesis of the effects of rules with respect to fiscal discipline and stabilisation

\begin{tabular}{l|c|c|c|c}
\hline & Budget balance & Structural balance & Expenditure rule & Revenue rule \\
\hline Fiscal stabilisation & - & + & + & - \\
Fiscal discipline & ++ & + & + & -+ \\
Side-effects and risks & - & -- & - & - \\
\hline
\end{tabular}

Source: OECD calculations, based on Table 4.

The macroeconomic model, set out in Box 3 , is used to illustrate the impact of a budget balance rule combined with a spending rule. In the central scenario, the primary balance follows the estimated primary balance reaction function (Figure 14, Panel A). The budget balance and spending rules lead to a higher primary balance surplus and, thus, to a lower public debt path (Figure 14, Panel B).

Figure 14. Illustration of a budget balance rule combined with a spending rule: The US example

Panel A. Past behaviour primary balance
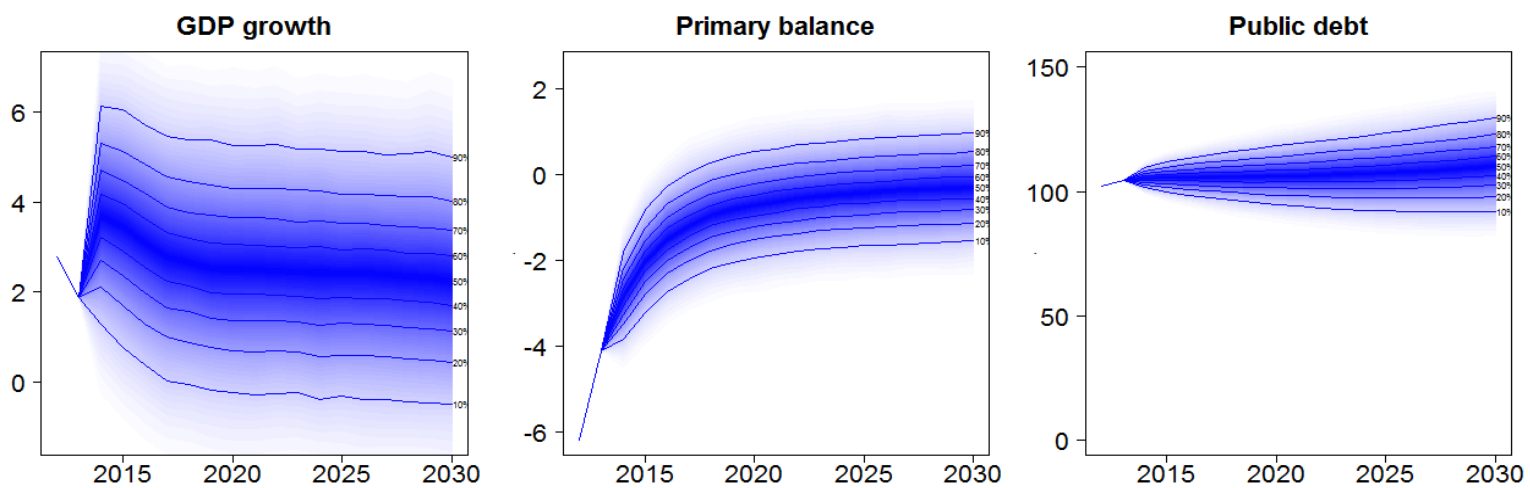

Panel B. Budget balance rule + spending rule
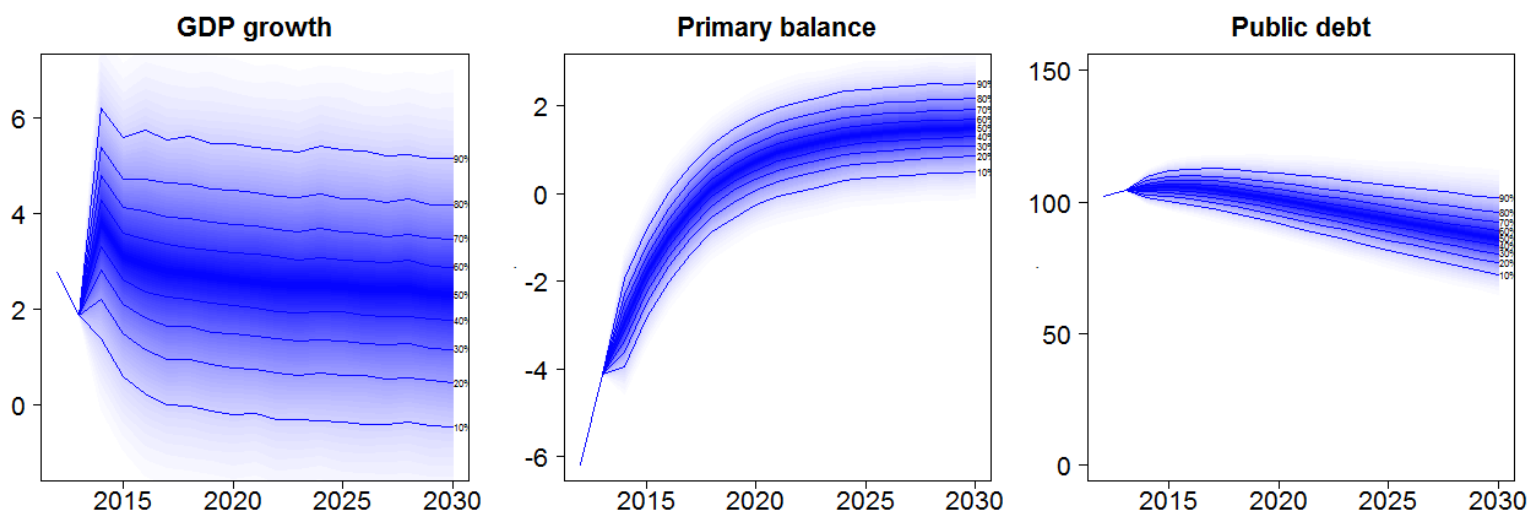

Source: OECD calculations.

Tail events happen, but they need not undermine credibility. Clear escape clauses should be set allowing the temporary suspension of fiscal rules. A temporary suspension should be conditional on exceptional events such as natural catastrophes or a sharp output contraction. However, the definition of 
these escape clauses must be clear to make sure they cannot be used in normal times. Determining the existence of exceptional circumstances can be delegated to a body outside the government or submitted to a validation by qualified majority in the parliament. To cope with tail events, a "rainy day" fund can underpin the respect of the rule over the cycle and would allow greater room for fiscal stabilisation. Unexpected surpluses would be saved and used later to finance unexpected deficits and/or short-term stabilisation policies.

In the design of fiscal rules two cases should be considered: countries pursuing fiscal consolidation towards a lower prudent debt target and countries for which the starting debt level is already below or around the medium to long-run prudent debt target.

\section{Fiscal rules for countries in transition towards a lower prudent debt level}

For countries in transition towards a prudent debt level, a path either in terms of budget balance or debt needs to be defined. The consolidation path links the current debt level to the prudent debt target.

There are many OECD studies on consolidation strategies that provide useful lessons. Rawdanowicz (2012) shows that it is possible to choose an optimal consolidation path to bring the deficit down and stabilise debt at a long-run target in a finite horizon. A previous OECD project on fiscal consolidation (Sutherland et al. (2012), Barrell et al. (2012) and Merola and Sutherland (2012) stressed the need to structure a consolidation strategy such that instruments with low multipliers are used initially and to enhance the institutional framework for fiscal policy in order to minimise the trade-offs with growth in the short run. Hageman (2012) shows that in most countries there is scope to target spending programmes more effectively and eliminate distortions in taxation. Moreover, Cournède et al. (2013) find that there is room in half of the OECD countries to reduce debt mainly through adjustments in instruments (such as subsidies, pensions or property taxes) that have at most limited side-effects on other policy objectives, such as growth or equity.

Finally, the consolidation strategy should involve all levels of government. During past consolidation episodes, sub-central governments helped stabilise general government debt. In general, consolidation at the state and - albeit less - at the local level increased the success of debt stabilisation at the general government level (Blöchliger et al., 2012).

Therefore, choosing the consolidation path is the cornerstone of the calibration of fiscal rules (budget balance rule complemented by an expenditure rule). ${ }^{7}$ Once the consolidation path is defined in terms of the debt trajectory toward the prudent debt level, the corresponding budget balance and spending rules can be deducted. The stringency of the consolidation path and of the fiscal rules depends on the time horizon to reach the prudent debt level, which may depend on the distance to the prudent debt target. Also, the stringency of the fiscal rules can be kept constant or increased to minimise the risk of missing the timing and the target. When fiscal consolidation is initiated under pressure, then it may be important to build credibility by imposing more stringency from the beginning.

The fiscal rule should include a mechanism to correct for past slippages in upcoming budgets. This could be achieved by means of rules similar to the German "debt brake", where fiscal slippages are recorded in a special account that has to be balanced over time (Baumann and Kastrop, 2007 and Kastrop et al., 2010). 


\section{Fiscal rules for preserving prudent debt levels}

For countries that are already close to the debt target, the objectives of the rules are to guarantee debt stability while allowing for stabilisation policies. If the objective is only to stabilise the debt level, then the primary balance needs to be equal to the real cost (difference between real interest rate and real growth times the debt level) of debt. But, as the objective is also to include room for macroeconomic stabilisation, the rules need to allow enough flexibility to dampen fluctuations in economic activity.

There are three dimensions that need to be taken into account when designing the rule:

- First, annual budgeting for year $\mathrm{t}$ is realised in year $\mathrm{t}-1$ based on the projections of macroeconomic variables. There is a need for an independent fiscal institution to ensure unbiased projections (see below). However, even with a fiscal institution, realised variables will likely differ from the projections. Thus the rules should allow for contemporaneous involuntary (unexpected shocks, automatic stabilisers) or voluntary (fiscal stabilisation) deviations.

- Second, because of these contemporaneous deviations, the rules should also include a backward dimension requiring that past deviations get offset over a limited amount of time. That is, the stringency of the budget balance and the spending rules is increased over time up to full correction, taking the form of a binding constraint of ex-post corrections of deviations.

- Third, there is a need to anchor the spending path. A medium-term budget framework, in which the government sets a spending trajectory over the medium term complements the budget rule and enhances its effectiveness (see below).

\section{Country-specific macroeconomic properties and fiscal rules}

The macroeconomic properties of countries differ in terms of the business cycle, trade openness, and exposition to financial developments that can affect the suitability of fiscal rules. The small macroeconomic model developed to assess the macroeconomic uncertainties surrounding debt developments is used to assess how different rules perform for the different countries in terms of debt uncertainty and recession risk.

First, the central scenario presented in Box 3 is used to simulate the dynamics of the six main variables (the growth rate $g_{i t}$, the inflation rate $\pi_{i t}$, the overnight nominal interest rate $r_{i t}^{s}$, the long-term nominal interest rate $r_{i t}^{l}$, the primary balance $P B_{i t}$, and the structural primary balance $\left.P B_{i t}^{s t}\right)$. But, the primary balance equation (fiscal reaction estimations) is replaced by stylised fiscal rules to determine the primary balance and therefore debt developments. Short-term shocks are jointly-drawn as defined in Box 3 and Fall and Fournier (2015).

Box 4 presents the different fiscal rules that are simulated. In the simulations, the rules are mechanically binding. However, governments have room to take discretionary fiscal measures in practice. Adding random discretionary spending to this framework would increase the uncertainties of the debt path. 


\section{Box 4. Simulated fiscal rules}

Six rules are simulated:

- In the baseline simulation, the annual budget plan is set so that the primary balance is equal to the target if the output gap is in line with expectations. During the year, the government lets the automatic stabilizers play around this plan (equation 1). The primary balance target is set to zero for countries that do not need to generate a surplus to reach a prudent debt level by 2040 . For the other countries, the primary balance target is adjusted so that the prudent debt level is reached in 2040.

(1) $B_{t}=$ balance target $+\alpha \cdot\left(g_{a p}-E_{t-1}\left(g_{a p}\right)\right)-r \cdot D_{t-1}$

- Two simulations are considered to investigate the counter-cyclical role of fiscal policy. In the first one, there are no automatic stabilisers, that is, the primary balance is kept constant such that the prudent debt target is reached (equation 2).

(2) $\quad B_{t}=$ balance target $-r \cdot D_{t-1}$

- In the second one, the government is assumed to take discretionary measures $(\alpha=0.4)$ on top of automatic stabilisers to react to the output gap (equation 3).

(3) $\quad B_{t}=$ balance target $+\alpha \cdot\left(g a p_{t}-E_{t-1}\left(g a p_{t}\right)\right)+\alpha \cdot g a p_{t}-r \cdot D_{t-1}$

- The effect of a spending rule is investigated in a simulation in which structural spending grows less fast than GDP so that the structural spending to GDP ratio decreases by 0.5 GDP point each year, for countries for which the structural spending level is above the pre-crisis OECD average (37\%). In this simulation, the primary balance follows the same path as in the baseline (equation 4).

(4) $\left\{\begin{array}{c}B_{t}=\text { balance target }+\alpha \cdot\left(\text { gap }_{t}-E_{t-1}\left(\text { gap }_{t}\right)\right)-r \cdot D_{t-1} \\ S_{t}=\min \left(S_{t-1}-0.5, S^{T}\right) \text { if } S_{t-1}>S^{T}\end{array}\right.$

- The role of frontloading is investigated. If lagged debt is higher than the debt ceiling, then the government generates an additional surplus equal to one $20^{\text {th }}$ of the difference between lagged debt and this ceiling. This comes on top of the effort made otherwise, which is set with the aim to reach a prudent debt level by 2040 (equation 5).

(5) $\quad B_{t}=$ balance target $+0.05 * \max \left(D_{t-1}-D^{T}, 0\right)+\alpha \cdot\left(g_{a p}-E_{t-1}\left(g a p_{t}\right)\right)-r \cdot D_{t-1}$

- The government's target is set in terms of the actual balance including interest payments, instead of the primary balance (equation 6).

(6) $\quad B_{t}=$ balance target $+\alpha \cdot\left(g_{a p}-E_{t-1}\left(g a p_{t}\right)\right)$

$B_{t}$ denotes the government balance, $\alpha$ is the elasticity of the primary balance to the output gap, $g_{a} p_{t}$ denotes the output gap, $D_{t-1}$ denotes the debt ratio in the previous year, $S_{t}$ denotes the structural level of government spending in per cent of GDP, $S^{T}$ the targeted level of structural spending in per cent of GDP and $D^{T}$ the debt ceiling.

Second, two criteria are used to benchmark the performance of the different rules in the model: the long-term recession risk, measured by the probability of GDP per capita growth to become negative and the uncertainty surrounding the debt trajectory, assessed by the interquartile range of the debt level in 2040. The uncertainties surrounding the debt trajectory can be reduced by debt management. For instance, longer debt maturities reduce roll-over risks, but at the cost of higher interest payments. 
The simulations suggest the following:

- The capacity of fiscal policy to mitigate shocks and its adverse consequence on debt trajectory uncertainty varies substantially across countries. Rules with stimulus compared to the baseline scenario reveal that highly indebted countries have less potential to counteract large adverse shocks, due to the binding budget balance component and the higher debt and GDP growth uncertainties.

- Spending rules entail no trade-off between minimising recession risks and minimising debt uncertainties. They can boost potential growth and hence reduce the recession risk without any adverse effect on debt. Indeed, estimations show that public spending restraint is associated with higher potential growth (Fall and Fournier, 2015).

- For all countries, sticking to initial annual budget plans and restoring the primary balance in the following years reduces debt uncertainty without a substantial increase of recession risks. In terms of cyclical corrections, the budget balance rule compares well with the structural balance rule because when setting each year a numerical target, the deviations due to the cycle can be taken into account. That is, the correction of the budget balance target due to the cycle can be incorporated ex-post.

- Rules based on a measure of the balance that includes interest payments are useful to reduce debt trajectory uncertainty in countries in transition towards a prudent debt level.

Countries are grouped into six groups depending on a combination of their characteristics and their responses to the different rules. Four criteria are used for the grouping of countries: the effectiveness of counter-cyclical fiscal policy, having room to restrain spending, belonging to the euro area ${ }^{8}$ and consolidation needs. In the first group are countries where fiscal policy has a strong counter-cyclical effect and where this strong effect does not have a large effect on the uncertainty surrounding the debt path (see Fall and Fournier, 2015 for details). In the second group are countries with a low level of public spending and a moderate effectiveness of fiscal policy to damp short-term shocks. The third group includes countries that have room for spending restraint, but excluding those euro area countries that need to generate large primary surpluses. The fourth group includes the euro area countries that face a moderate need to consolidate and have room to restrain spending. The fifth group gathers euro area countries that need to raise the primary balance to $2 \%$ of GDP or even more to hit the prudent debt ratio in 2040. Last, Japan has such a high debt level, that hitting a prudent debt target by 2040 would imply an unrealistically large fiscal tightening in the short run.

The fiscal rules have a different performance with regard to the two criteria (long term recession risks and debt uncertainties) for six groups of countries (Figure 15):

- Group 1 (Australia, Israel, Korea, New Zealand, Poland, Switzerland and the United States): Countries that can rely more on fiscal policy to mitigate short-term shocks. In these countries, a stronger reaction of fiscal policy to the cycle is efficient in reducing recession risks with a moderate cost in terms of debt uncertainty. Among these countries, the United States also needs to generate surpluses to bring debt back to a prudent level.

- Group 2 (Canada, Czech and Slovak Republic): Countries with a low level of public spending and a moderate effectiveness of fiscal policy to damp short-term shocks. The low level of public spending reveals there is little to gain from focusing on spending restraint, but a spending rule that makes sure this low level remains in the long run is appropriate. In these countries, counter-cyclical policy entails a considerable rise in debt uncertainty for a moderate reduction of recession risks.

8. Belonging to the euro area is a criterion, because of the absence of monetary policy at the country level. 
- $\quad$ Group 3 (Denmark, Luxembourg, Sweden and the United Kingdom): These countries have room for spending restraint. These countries do not need to generate primary surpluses to target a prudent debt level by 2040 , except the UK that needs to generate a moderate one. In Luxembourg and Sweden, a stronger reliance on fiscal policy to mitigate short-term shocks would increase debt uncertainty with moderate gains in terms of lowering recession risks.

- Group 4 (Austria, Belgium, Finland, France, Germany, the Netherlands and Slovenia): These euro area countries need to generate primary surpluses and Germany has to keep a primary surplus to bring debt back to a prudent level and they should restrain spending. These countries need both a spending and a debt rule to stick to the debt trajectory.

- Group 5 (Greece, Ireland, Italy, Portugal and Spain): These euro area countries need to generate large primary surpluses. These countries also face a large debt dynamics uncertainty. This uncertainty can be reduced with a debt rule, and by making sure that any widening of the primary balance triggered by a weaker economy is temporary. Because of the debt dynamics uncertainty, they have little room to mitigate recession risks with fiscal policy.

- Group 6 (Japan): The most indebted country is in a class of its own. Japan needs to reduce debt, but this process should be protracted as there is no strong adverse effect of the debt level on interest rates. Setting a prudent debt target by 2040 implies an unrealistic and unnecessarily large fiscal tightening in the short run. Counter-cyclical fiscal policy should not be used intensively as it leads to large debt trajectory uncertainty for quite a small reduction of recession risks. The low level of public spending suggests that most of the consolidation effort will have to come from the revenue side. 
Figure 15. Comparison of fiscal rules by country group

Panel A. Long-term recession risks

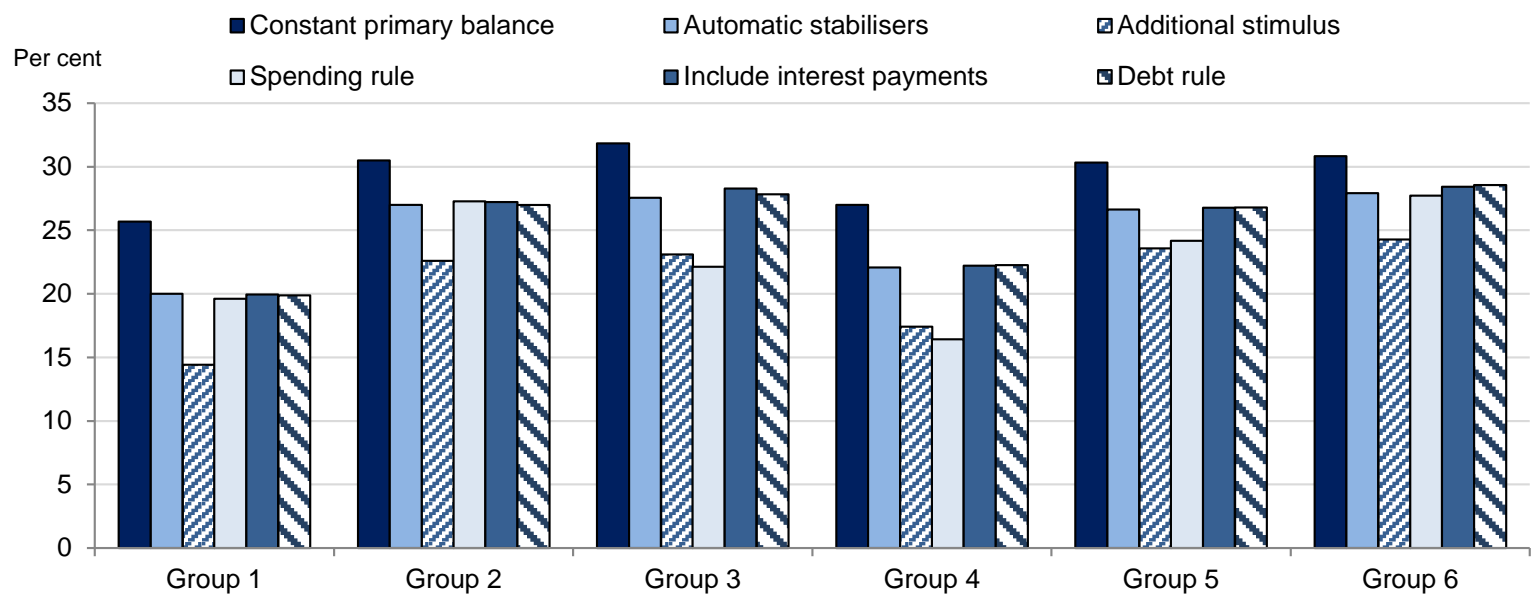

Panel B. Debt level uncertainties

Per cent GDP

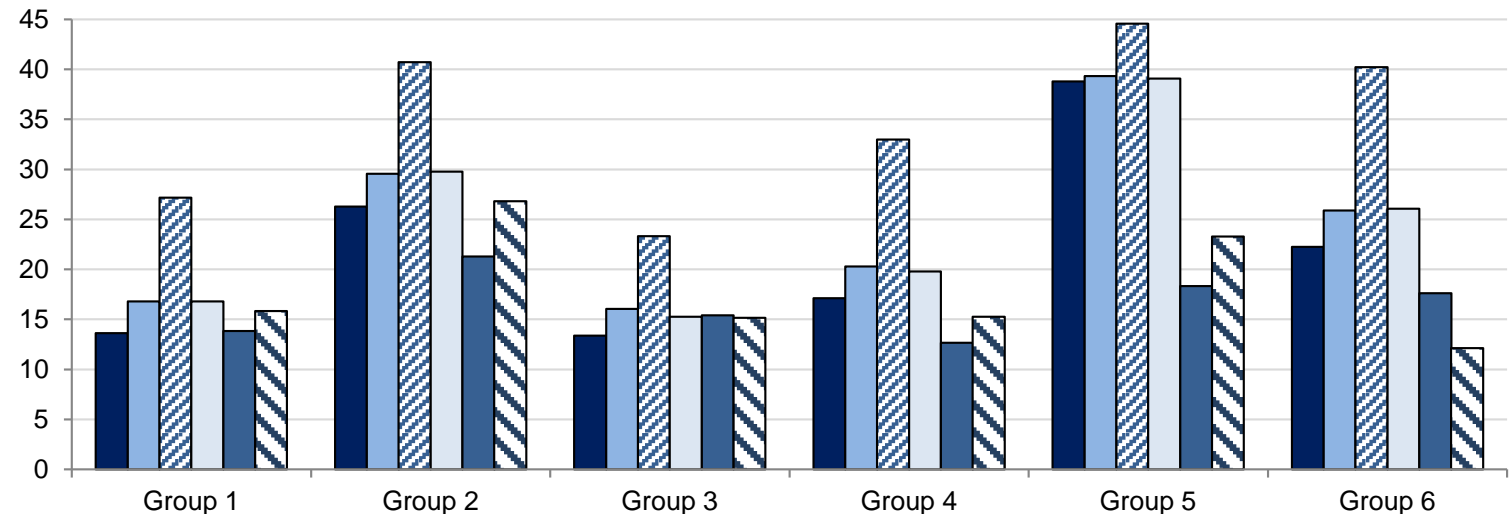

StatLink 게재 http://dx.doi.org/10.1787/888933224084

Note: The bars are averages for the countries in the group. The "Constant primary balance" simulation is a stylised scenario in which the actual primary balance is kept constant such that the prudent debt target is reached, with no automatic stabilisers. In the scenario labelled "Automatic stabilisers", a one percentage point negative surprise in the output gap is associated with a $0.4 \%$ of GDP temporary stimulus. In the "Additional stimulus" scenario, the government is taking discretionary measures on top of automatic stabilisers to react to the output gap. In the "Spending rule" scenario, the government lets the automatic stabilisers play during the current year only as in the baseline (rule 1); and structural spending grows by 0.5 percentage points less than potential GDP, for countries for which the structural spending level is above the pre-crisis OECD average (37\%) until it reaches this average. In the "Include interest payments" scenario, the government's target is set in terms of the actual balance including interest payments, instead of the primary balance. In the "Debt rule" or frontloading scenario, the primary balance is increased by one twentieth of the difference between the debt level and its ceiling when debt is above this ceiling. This comes on top of the effort made otherwise. The long-term recession risk is the probability that GDP per capita growth becomes negative. The uncertainty surrounding the debt trajectory is assessed by the interquartile range of the debt level in 2040.

Source: OECD calculations. 
The simulation results are summarised in Table 8.

Table 8. Simulation results: Grouping of countries and fiscal rules

\begin{tabular}{l|l}
\hline \multicolumn{1}{c|}{ Groups of countries } & \multicolumn{1}{c}{ Rules } \\
\hline $\begin{array}{l}\text { Group 1: Australia, Israel, Korea, New Zealand, Poland, } \\
\text { Switzerland and the United States }\end{array}$ & $\begin{array}{l}\text { Budget balance rule and considerable room for counter- } \\
\text { cyclical fiscal policy }\end{array}$ \\
$\begin{array}{l}\text { Group 2: Canada, Czech and Slovak Republic } \\
\text { Group 3: Denmark, Luxembourg, Sweden and the United } \\
\text { Kingdom }\end{array}$ & $\begin{array}{l}\text { Budget balance rule } \\
\text { Broup 4: Austria, Belgium, Finland, France, Germany, the rule and spending rule with some bite } \\
\text { Netherlands and Slovenia }\end{array}$ \\
$\begin{array}{l}\text { Group 5: Greece, Ireland, Italy, Portugal and Spain } \\
\text { Group 6: Japan }\end{array}$ & $\begin{array}{l}\text { Budget balance rule and spending rule with strong bite } \\
\text { surplus with some frontloading }\end{array}$ \\
\hline
\end{tabular}

1. The United Kingdom has a spending-to-GDP ratio somewhat above the OECD average, while the other countries in this group have high spending ratios.

Source: OECD calculations.

\subsection{Fiscal councils}

There is a growing literature on the design of fiscal councils and their effectiveness (see for surveys Debrun et al. 2009, Hagemann, 2011, Kopits, 2011b, and Debrun and Kinda, 2014). This section reviews the arguments for setting up fiscal councils, their role and the conditions for their effectiveness.

\section{Why do we need a fiscal council?}

Fiscal councils foster fiscal discipline and thereby complement fiscal rules. As the rules are designed to hit fiscal targets and allow for stabilisation policies, deficit bias behaviour should be disentangled from accommodation of short-run shocks to make sure that governments respect their commitments. To that end, an external body can verify whether the government complies with the fiscal rules.

A fiscal council can underpin transparency and thus credibility. The adoption of fiscal rules, in particular of complex rules, increases the need for transparency. Governments may be biased toward overestimating expected revenues, underestimating spending, or unduly exercise escape clauses (Debrun et al. 2013). A fiscal council can help discipline government behaviour.

Finally, a fiscal council can help address the common-pool problem, in particular in federal states, by warning on externalities of fiscal policies generated by sub-central governments that may benefit them at the expense of others.

\section{Design and remit of fiscal institutions}

The role of fiscal councils is to monitor ex ante that fiscal policy is likely to meet the short and long-run targets while allowing fiscal flexibility. Rating agencies have shown clear limitations in terms of monitoring public finances.

There is "no one size fits all" in terms of designing a fiscal council. The design should depend on the country's political culture, legal traditions and economic characteristics. In some countries, a fiscal council with a monitoring role is not deemed necessary due the high standards of accountability and transparency already in place (New Zealand); while in others, an independent authority is in charge of fiscal surveillance (United Kingdom). 
Fiscal councils often have very different roles and remits. In addition to analysis of budget proposals and current fiscal developments, common functions include producing independent projections and forecasts or endorsing or assessing government projections and forecasts; monitoring compliance with fiscal rules and targets; analysis of long-term fiscal sustainability; costing of policy proposals; and analytical studies on selected issues. A minority of fiscal councils also provide normative assessments.

The exact combination of these features in the remit of the fiscal council should be guided by the weaknesses of and risks surrounding fiscal policy. Table 9 shows the different mandates of existing fiscal councils. If the government tends to miss its targets due to over-optimistic fiscal projections, then these forecasts should be delegated to a fiscal council, or alternatively a council could audit government forecasts. If the main issue is insufficient assessment of the long-run consequences of decisions, providing fiscal sustainability calculations highlighting these consequences might alleviate the bias.

Another important role for fiscal councils is the assessment of the need for counter-cyclical fiscal policy. Governments often miss the opportunity to build fiscal buffers in good times and a council could call for adjustments in that case. Moreover, when the government calls for the application of escape clauses to deviate from the fiscal rules, then the fiscal council could be in charge of assessing the correctness of this call.

\section{Conditions for the effectiveness of a fiscal institution}

Fiscal councils are relatively new, but their number within the OECD has tripled since the crisis started to 20 in 2013. They differ in terms of mandate and features, and the qualitative nature of an important part of their work renders the assessment of their effectiveness difficult. In addition, the analysis is subject to reverse causation as there is the possibility that disciplined countries reveal their preferences by adopting such institutions.

The estimations in Table 6 show that it is difficult to capture the effectiveness of fiscal councils. The impact of fiscal councils on the primary balance is not significant in most of the specifications. However, fiscal councils appear to limit spending when associated with a budget balance rule (Table 6, Column S2).

These results are in line with the findings by Debrun et al. (2013) who conducted a thorough analysis of the performance of fiscal councils. On average the mere existence of a fiscal council appears only loosely related to stronger fiscal outcomes. But, higher primary balances are associated with fiscal councils featuring certain characteristics. For instance, the task of monitoring compliance with fiscal rules is unlikely to be sufficient to affect fiscal performance if it is not paired with strict independence and a presence in the public debate. They also find that, in the European Union, countries with fiscal councils have stronger fiscal positions, more accurate and less optimistic forecasts and policy is less pro-cyclical. 
Table 9. The remit of fiscal institutions in OECD countries

\begin{tabular}{|c|c|c|c|c|c|c|c|c|c|c|}
\hline & & $\begin{array}{l}\text { Normative } \\
\text { analysis }\end{array}$ & $\begin{array}{l}\text { Forecast } \\
\text { preparation }\end{array}$ & $\begin{array}{l}\text { Forecast } \\
\text { assessment }\end{array}$ & $\begin{array}{l}\text { Long-term } \\
\text { sustainability }^{1}\end{array}$ & Optimality $^{2}$ & $\begin{array}{l}\text { Costing of } \\
\text { measures }^{3}\end{array}$ & $\begin{array}{l}\text { Monitoring of } \\
\text { fiscal fules }\end{array}$ & $\begin{array}{l}\text { Ex-post } \\
\text { analysis }\end{array}$ & $\begin{array}{l}\text { Mandate } \\
\text { beyond } \\
\text { fiscal policy }\end{array}$ \\
\hline Australia & Parliamentary Budget Office & & & & $x$ & & $x$ & & & \\
\hline Austria & Fiscal Advisory Council & $\mathrm{x}$ & & & $X$ & $\mathrm{x}$ & & $\mathrm{x}$ & $x$ & \\
\hline Belgium & High Council of Finance & $x$ & & & $x$ & & & $x$ & $x$ & \\
\hline Belgium & Federal Planning Bureau & & $x$ & $x$ & $x$ & $x$ & & & $x$ & $x$ \\
\hline Canada & Parliamentary Budget Office & & $x$ & $x$ & $x$ & $x$ & $x$ & & $x$ & \\
\hline Denmark & Danish Economic Council & $x$ & $x$ & $x$ & $x$ & $x$ & & $x$ & $x$ & $x$ \\
\hline Finland & National Audit Office of Finland & $x$ & & $\mathrm{x}$ & $x$ & $\mathrm{x}$ & & $x$ & $x$ & \\
\hline France & High Council of Public Finance & & & $x$ & & $x$ & & $x$ & $x$ & \\
\hline Germany & Stability Council & $x$ & & $x$ & $x$ & $x$ & & $x$ & $x$ & \\
\hline Hungary $^{4}$ & Fiscal Council & & $x$ & $x$ & & $x$ & $x$ & $x$ & $x$ & \\
\hline Ireland & Irish Fiscal Advisory Council & $x$ & & $x$ & $x$ & $x$ & & $x$ & $x$ & \\
\hline Italy & Parliamentary Budget Office & & & $x$ & $x$ & $x$ & $\mathrm{x}$ & $x$ & $x$ & \\
\hline Japan & $\begin{array}{l}\text { Fiscal System Council and Council on Economic } \\
\text { and Fiscal Policy }\end{array}$ & $x$ & & & & & & & & $x$ \\
\hline Korea & National Assembly Budget Office & & $x$ & $x$ & $x$ & $x$ & $\mathrm{x}$ & & $x$ & \\
\hline Mexico & Center for Public Finance Studies & & $x$ & $x$ & & & $x$ & & & $x$ \\
\hline Netherlands & $\begin{array}{l}\text { Netherlands CPB Bureau for Economic Policy } \\
\text { Analysis }\end{array}$ & & $x$ & & $\mathrm{X}$ & $x$ & $x$ & $x$ & $x$ & $\mathrm{X}$ \\
\hline Portugal & Portuguese Public Finance Council & & & $\mathrm{x}$ & $x$ & $\mathrm{x}$ & & $\mathrm{X}$ & $\mathrm{x}$ & \\
\hline Slovak Republic & Council for Budget Responsibility & & & & $\mathrm{x}$ & $x$ & $x$ & $\mathrm{X}$ & $\mathrm{X}$ & \\
\hline Slovenia & $\begin{array}{l}\text { Institute of Macroeconomic Analysis and } \\
\text { Development }\end{array}$ & $x$ & $x$ & $x$ & $x$ & $x$ & & & $x$ & $x$ \\
\hline Slovenia & Fiscal Council & & & & $x$ & $x$ & & $x$ & $x$ & \\
\hline Sweden & Swedish Fiscal Policy Council & $x$ & & & $x$ & $x$ & & $x$ & $x$ & \\
\hline United Kingdom & Office for Budget Responsibility & & $x$ & $x$ & $x$ & $x$ & $x$ & $x$ & $x$ & \\
\hline United States & Congressional Budget Office & & $x$ & $x$ & $x$ & & $\mathrm{x}$ & & $x$ & \\
\hline
\end{tabular}

1. Long-term sustainability is defined as the long-term forecast of government balance and debt level.

2. "Optimality" is defined as the assessment of government budgetary and fiscal performance in relation to fiscal objectives and strategic priorities.

3. "Costing of Measures" is defined as the quantification of either short-term or long-term effects, or both, of measures and reforms.

4. The council has been significantly weakened in 2010 .

Source: IMF Fiscal Council Dataset (February 2014) and OECD (2015), Principles for Independent Fiscal Institutions and Country Notes, forthcoming. 
These empirical findings are in line with Kopits (2011a; 2011b), who identifies the following features as critical for the effectiveness of a fiscal institution: a) home-grown and home-owned design and operations; b) independence, non-partisanship, technical competence, and accountability to the legislature; c) sufficient technical support staff, with unlimited access to timely information from the government; d) a remit consisting of the assessment of the fiscal stance and debt sustainability - including monitoring of the compliance with rules or targets - through real-time estimation of the budgetary effects of legislative proposals; and e) effective means of communication to the public, ensuring a high level of transparency.

These features correspond to the principles for independent fiscal institutions agreed by OECD member countries set out in OECD (2014). Among the nine headline principles emerge the key roles of the relationship with the legislature and the involvement in budget procedure, independence and nonpartisanship and access to information for an effective fiscal institution.

\subsection{Medium-term budgetary frameworks}

A medium-term budgetary framework (MTBF) is useful for the effectiveness of the fiscal framework. The role of the MTBF is to guarantee time-consistency between policies and targets. The MTBF is crucial to convert fiscal targets into detailed revenue and expenditure plans. Successful medium-term budget frameworks provide binding restrictions on multi-year expenditure and a clear and consistent statement of the government's medium-term priorities within an overall expenditure ceiling (Gupta and Yläoutinen, 2014).

The MTBF needs to be anchored in medium-term numerical objectives (Blondal, 2005). These objectives are intermediary objectives in line with the long-term fiscal targets. Fixed medium-term objectives imply that fiscal rules (budget and spending targets) are not adjusted over time unless unexpected exceptional events arise during the period covered by the framework. For instance, in the Netherlands, Sweden, Finland and the new framework in the United Kingdom, the MTBFs are based on a multi-annual spending rule providing binding expenditure limits. In the case of the Netherlands, each newly elected government announces its medium-term budgetary objectives in accordance with the long- run fiscal target. Then, over the legislature, policies are assessed with regard to their impact on the target.

The key factor in the effectiveness of a medium-term budgetary framework is its influence on annual budgeting. The medium-term path derived from the MTBF should be binding for the budget balance and spending rules. The ex-ante setting of numerical targets for the budget balance and spending rules from the MTBF implies an adjustment of spending and revenue plans to ensure the respect of the different targets. In particular, a prioritisation of spending plans is necessary to make sure that whenever cuts in spending are necessary to respect the fiscal framework, it will not hit policy priorities.

The MTBF is subject to the same risks as fiscal rules, which include non-binding fiscal targets, limited political commitment and rosy projections. Therefore, as for fiscal rules, a fiscal council is needed to guarantee transparency and credibility of the framework.

\subsection{Budgetary procedures}

The budgetary process is also important in ensuring that fiscal rules, in particular spending targets, are met. OECD (2014) sets out the principles of budgetary governance agreed by OECD member countries. Along the ten headline principles emerge the key roles of transparency, sincerity and coordination. Countries deemed successful in the implementation of their fiscal framework (Sweden and the Netherland, for instance) have a centralised budget process (Ministry of finance, Central Budget Administration) ensuring the consistency between ex-ante spending plans and actual spending. Also the centralisation of budgeting procedures is deemed necessary for the effectiveness of top-down budgeting $(E C, 2010)$. In particular, the central budget office should have the possibility to veto any over-spending until a new law is voted to authorise it.

Successful budgetary procedures are likely to be country-specific depending on the size of the country, its central or federal nature and the features of the political system. Von Hagen and Harden (1994) 
find that budget processes of all governments of large states that successfully limited spending and deficits in the 1970s and 1980s (France, Britain, and Germany) are based on a procedure-oriented approach, that is when there is a process of negotiations between spending ministers and a central minister (budget or finance) which has some power. In contrast, the budget processes of smaller countries (Denmark, the Netherlands and Luxembourg) that successfully limited spending and deficits are target-oriented. This suggests that country size matters for the complexity of administrations, which makes it more difficult to monitor compliance with numerical budget targets.

OECD (2014) and Gupta and Yläoutinen (2014) find that top-down budgeting is one of the key elements that underpin a credible fiscal strategy. In particular, during fiscal consolidation episodes, a topdown budgeting approach imposes limits to spending both at the aggregate and sectoral level, which increases the likelihood that the budget execution is consistent with the ex-ante fiscal plan. The spending limit can be reinforced by requiring that a particular expenditure item cannot be raised without cutting spending within the same area.

\section{Political economy issues}

\subsection{The credibility of the consolidation path matters for avoiding fiscal fatigue}

The choice of the consolidation path is crucial to limit the occurrence of fiscal fatigue, which could lead to higher interest rates with negative effects on demand. It takes time to bring debt back to a prudent level. In recent years, successful fiscal consolidation policies took on average ten years. Canada's consolidation started in 1993 and was interrupted only by the 2008-09 crises. For Belgium, the Netherlands and Sweden, debt consolidation followed the same dynamics, starting in the mid-1990s and lasted more than ten years. Given these consolidation durations, a strong frontloading in the initial years, though deemed efficient, should be avoided and a smoother path privileged. For instance, it took seven years for Canada's debt-to-GDP ratio to decrease from 102\% in 1993 to $84 \%$ in 2000. During the four years to 1997, the improvement in the general government financial balance was significant, averaging $2 \%$ of GDP per annum.

\subsection{Political economy of fiscal consolidation}

Some political economy lessons can be drawn from successful fiscal consolidation episodes. Posner and Sommerfeld (2013) reviewed fiscal consolidation episodes lasting 6 to 9 years in Australia, Canada, New Zealand, Sweden and the United States. Many OECD countries experienced consolidation episodes that lasted over long periods and achieved much in terms of consolidation (Guichard et al., 2007). For instance, Blöchliger et al. (2012) found 13 cases of fiscal consolidation between 1980 and 2000 where deficits were reduced from $8 \%$ to $1 \%$ of GDP on average within five years. The lessons from Posner and Sommerfeld's (2013) review and case studies can be summarised as follows:

- Triggers for consolidation: As spending cuts or tax increases are contentious, they are seldom undertaken in normal times. As a general rule, fiscal consolidation is undertaken only when public finances are weak, as measured by rising deficits and debt levels (Molnar, 2012). Some studies suggest that a crisis is needed to get countries to undertake deeper and more prolonged consolidations (Larch and Turrini, 2008). For instance, Sweden undertook fiscal consolidation policies after unemployment jumped from $2 \%$ in 1990 to $8 \%$ in 1993, a budget deficit of 12\% of GDP in 1993 and negative growth.

- Economic context: There is a tension between fiscal austerity and growth. However, many countries undertake consolidation during times when economies have emerged from recessions. In these times, deficit reduction can boost growth, partly by convincing central banks and markets to lower interest rates (Von Hagen and Strauch, 2001). For instance, Sweden undertook significant deficit reduction in 1994 just as its economy was embarking on a strong recovery. 
- Political institutions and timing: Successful consolidations require strategic timing and strong support from political parties. With regard to timing, governments are most successful when consolidations are introduced in the immediate aftermath of an election (Guichard et al., 2007). A mandate to consolidate is also important: for instance, the newly elected governments of Canada and Sweden had both campaigned on the need for consolidation, providing a mandate for strong action. The research is ambiguous with regard to the impact of strong ruling parties on the prospects for fiscal consolidation. However, strong majorities (one party ruling majority, unified presidential majority, bi-partisan coalition) are associated with more decisive action, longer lasting fiscal consolidations and fundamental reforms of major spending areas (Alesina et al., 2006 and Larch and Turrini, 2008).

- The composition of consolidation initiatives: Sharing sacrifices and balancing spending and revenue actions can help to cushion the view that consolidation is unfair or at the advantage of specific groups. For instance, Sweden imposed an $11 \%$ across-the-board cut on nearly all programmes and agencies at the outset of its consolidation in 1994. Compensating losers with packages that cement coalitions by providing gains to offset a portion of the losses of major groups is also a strategy.

- Political competition and consolidation: Conventional wisdom suggests that political leaders are short-sighted, and the political rewards of consolidation are likely to be overshadowed by nearterm political considerations. Brender and Drazen (2006) found that governments achieving lower deficits through policy actions actually increased the probability of their re-election. Using data on 164 elections from 23 OECD countries from 1960 through 2003, they found that controlling for changes in the economy, a reduction of 1 percentage point in the deficit/GDP ratio increased the probability of re-election for existing governments by 5.7 percentage points.

- Alesina et al. (1998) find that during sharp adjustments that rely primarily on spending cuts and, in particular, on the major components of government wages and transfers, the probability of government survival increased. Also Posner and Sommerfeld (2013) find that the nine OECD countries running persistent surpluses were re-elected in $63 \%$ of the 24 elections in the eight years up to the Great Recession. By contrast, countries with the highest deficits during this period were re-elected $40 \%$ of the time. More importantly, the governments in surplus countries had far greater success in elections following the Great Recession. Incumbent governments won in six of eight elections in the surplus group, but only won in one of the five elections in the deficit group.

- In the European countries hard hit by the crisis the ruling party that undertook important consolidation policies lost the following elections. In many of these countries, the legislature did not last until its term and elections were held in advance:

- Greece: The ruling party at the outset of the crisis (New Democracy) lost the election in October 2009. The winner Pasok, which undertook the consolidation policies lost the election in May-June 2012 by a wide margin. The New Democracy party, which succeeded and continued the consolidation progamme, lost also by a wide margin in January 2015.

- Ireland: The winner of the May 2007 election (Fianna Fáil) lost the February 2011 election after starting the consolidation programme.

- Portugal: The ruling party at the outset of the crisis (Socialist Party) won the September 2009 election by a small margin, but after undertaking the consolidation programme it lost the 2011 election.

- Spain: The Spanish socialist party won the 2008 election and in the aftermath of the crisis started the consolidation programme. It lost the 2011 election. 


\section{BIBLIOGRAPHY}

Afonso, A. and J. Alves ( 2014). "The Role of Government Debt in Economic Growth," Working Papers Department of Economics 2014/16, ISEG - School of Economics and Management, Department of Economics, University of Lisbon.

Aguiar, M. and M. Amador (2013), "Sovereign Debt: A Review", NBER Working Paper, No. 19388.

Alesina, A. and G. Tabellini (1990), "A Positive Theory of Fiscal Deficits and Dovernment Debt", The Review of Economic Studies, Vol. 7, Issue 3, pp. 403-414.

Alesina, A., S. Ardagna and F. Trebbi (2006), "Who Adjusts and When? On the Political Economy of Reforms", NBER Working Paper, No. 12049.

Alesina, A., R. Perotti and J. Tavares (1998), "The Political Economy of Fiscal Adjustments", Brookings Papers on Economic Activity, 1:197-266.

Alesina, A. and T. Bayoumi (1996), "The Costs and Benefits of Fiscal Rules: Evidence from U.S. States", NBER Working Paper, No. 5614.

Arellano, C. and N. R. Kocherlakota (2008), "Internal Debt Crises and Sovereign Defaults", NBER Working Paper, No. 13794.

Aschauer , D. A. (2000), "Do States Optimise? Public Capital and Economic Growth", Annals of Regional Science, Vol. 34, pp. 343-63.

Auerbach, A. and Y. Gorodnichenko (2012), "Measuring the Output Responses to Fiscal Policy", American Economic Journal: Economic Policy, Vol. 4(2), pp. 1-27.

Auerbach, A.J. (2002), "Is There a Role for Discretionary Fiscal Policy?", in Rethinking Stabilization Policy, a symposium sponsored by the Federal Reserve Bank of Kansas City, Jackson Hole (WY), August 29-31, pp. 109-50.

Ballagria, F. and C. Martinez-Mongay (2009), "A Further Inquire about the Sustainability of Fiscal Policy in the EU", in: Larch, M. and J. Nogueira-Martins (eds), Fiscal Policy Making in the European Union, Brussels.

Barnes, S. and D. Smyth (2013), The Government's Balance Sheet after the Crisis: A Comprehensive Perspective, Irish Fiscal Advisory Council.

Barrell, R., D. Holland and I. Hurst (2012), "Fiscal Consolidation: Part 2. Fiscal Multipliers and Fiscal Consolidations", OECD Economics Department Working Papers, No. 933, OECD Publishing, Paris.

Baum, A., Checherita - Westphal, C., and Rother, P. (2013), "Debt and Growth: New Evidence for the Euro Area", Journal of International Money and Finance, 32, 809-821.

Baumann, E. and C. Kastrop (2007), "A New Budget Rule for Germany", in Banca d'Italia (ed.), Fiscal Policy: Current Issues and Challenges, acts of the 9th Public Finance Workshop held in Perugia, 29-31 March.

Blanchard, O. J. and D. Leigh (2013), "Growth Forecast Errors and Fiscal Multipliers", IMF Working Paper, $13 / 01$. 
Bloch, D. and F. Fall (2015), "Government Debt Indicators: Understanding the Data", OECD Economics Department Working Papers, No. 1228, OECD Publishing, Paris.

Blöchliger, H. (2013), "Fiscal Consolidation across Government Levels - Part 1. How Much, What Policies?", OECD Economic Department Working Paper, No. 1070. OECD Publishing, Paris.

Blöchliger, H., D. Song and D. Sutherland (2012), "Fiscal Consolidation: Part 4. Case Studies of Large Fiscal Consolidation Episodes", OECD Economics Department Working Papers, No. 935, OECD Publishing, Paris.

Blondal, J. (2005), "The Reform of Public Expenditure Management Systems in OECD Countries", in Banca d'Italia (ed.), Fiscal Policy: Public Expenditures, acts of the 7th Public Finance Workshop held in Perugia, 31 March - 2 April.

Bohn, H. and R. Inman (1996), "Balanced-budget Rules and Public Deficits: Evidence from the U.S. States", Carnegie-Rochester Conference Series on Public Policy.

Brender, A. and A. Drazen (2006), "Political Implications of Fiscal Performance in OECD Countries", in Banca d'Italia (ed.), Fiscal Policy: Fiscal Indicators, acts of the 8th Public Finance Workshop held in Perugia, 30 March - 1 Avril.

Calmfors, L. and S. Wren-Lewis (2011), "What Should Fiscal Councils Do?", Economic Policy, pp. 649-695.

Carlino G. and R. P. Inman (2013), "Local Deficits and Local Jobs: Can U.S. States Stabilize their own Economies?", NBER Working Paper, No. 18930.

Carnot, N. (2014), "Evaluating Fiscal Policy: A Rule of Thumb", European Economy, Economic Papers, No. 526.

Cecchetti, S., M. Mohanty and F. Zampolli ( 2011), "The Real Effects of Debt", BIS Working Papers, No. 352, Bank for International Settlements.

Checherita-Westphal, C., A. H. Hallett and P. Rother (2014), "Fiscal Sustainability Using Growthmaximizing Debt Targets", Applied Economics, Vol. 46(6), pp. 638-647.

Chudik, A., K. Mohaddes, H. Pesaran and M. Raissi (2013), "Debt, Inflation and Growth: Robust Estimation of Long-Run Effects in Dynamic Panel Data Models", Federal Reserve Bank of Dallas Globalization and Monetary Policy Institute Working Paper, No. 162.

Clemens, J. P. and S. I. Miran (2012), "Fiscal Policy Multipliers on Sub-National Government Spending", American Economic Journal: Economic Policy, 4, pp. 46-68.

Cournède, B., A. Goujard and Á. Pina (2013), "How to Achieve Growth- and Equity-friendly Fiscal Consolidation? A Proposed Methodology for Instrument Choice with an Illustrative Application to OECD Countries", OECD Economics Department Working Papers, No. 1088, OECD Publishing, Paris.

Debrun, X. and T. Kinda (2014), "Strengthening Post-Crisis Fiscal Credibility-Fiscal Councils on the Rise. A New Dataset", IMF Working Paper, WP/14/58.

Debrun X., T. Kinda, T. Curristine, L. Eyraud, J. Harris, and J. Seiwald, (2013), "The Functions and Impact of Fiscal Councils", IMF Policy Paper, July.

Debrun, X. et al. (2008), "Tied to the Mast? The Role of National Fiscal Rules in the European Union", Economic Policy, No. 54, pp. 298-362. 
Debrun, X., D. Hauner and M. Kumar (2009), "Independent Fiscal Agencies", Journal of Economic Surveys, No. 23, pp. 44-81.

Égert, B. (2013), "The 90\% Public Debt Threshold: The Rise and Fall of a Stylised Fact", OECD Economics Department Working Papers, No. 1055, OECD Publishing, Paris.

Égert, B. (2010), "Fiscal Policy Reaction to the Cycle in the OECD: Pro- or Counter-cyclical?", OECD Economics Department Working Papers, No. 763, OECD Publishing, Paris.

European Commission (EC) (2011), "Public Finances in EMU - 2011", European Economy, No. 4/2011, European Commission, Brussels.

European Commission (EC), 2010, "Public Finances in EMU - 2010", European Economy, No. 4/2010 European Commission, Brussels.

Eurostat (2015), "First Time Release of Data on Contingent Liabilities and Non-performing Loans in EU Member States", news release, http://ec.europa.eu/eurostat/documents/2995521/6616449/210022015-AP-EN.pdf/d75df6fe-100b-4ae7-a09e-00400edb183a.

Fall, F., D. Bloch, P. Hoeller, J.K. Pareliussen and M. Pisu (2014), "Vulnerability of Social Institutions", OECD Economic Policy Papers, No. 11, OECD Publishing, Paris.

Fall, F. and J-M. Fournier (2015), "Macroeconomic Uncertainties, Prudent Debt Targets and Fiscal Rules", OECD Economics Department Working Papers, No. 1230, OECD Publishing, Paris.

Fatás, A. and I. Mihov (2003), "The Case for Restricting Fiscal Policy Discretion", The Quarterly Journal of Economics, Vol. 118(4), pp. 1419-1447.

Fatas, A. and I. Mihov (2006), "The Macroeconomic Effects of Fiscal Rules in the US States", Journal of Public Economics, Vol. 90(1-2), pp. 101-117.

Fournier, J-M. and F. Fall (2015), "Limits to Government Debt Sustainability", OECD Economics Department Working Papers, No. 1229, OECD Publishing, Paris.

Galí, J., J. D. López-Salido, and J. Vallés (2007), "Understanding the Effects of Government Spending on Consumption", Journal of the European Economic Association, Vol. 5(1), pp. 227-70.

Ghosh, A. R., J. D. Ostry and M. S. Qureshi (2013), "Fiscal Space and Sovereign Risk Pricing in a Currency Union", Journal of International Money and Finance, Vol. 34, pp. 131-163.

Giavazzi, F. and M. Pagano (1990), "Can Severe Fiscal Contractions Be Expansionary? Tales of Two Small European Countries", in: NBER Macroeconomics Annual 1990, ed. by O. J. Blanchard and S. Fischer.

Guichard, S. et al. (2007), "What Promotes Fiscal Consolidation: OECD Country Experiences", OECD Economics Department Working Papers, No. 553, OECD Publishing, Paris.

Guillemette, Y. (2010), "A Simulation Model of Federal, Provincial and Territorial Government Accounts for the Analysis of Fiscal Consolidation Strategies in Canada", OECD Economics Department Working Papers, No. 818, OECD Publishing, Paris.

Gupta, S. and S. Yläoutinen (2014), "Budget Institutions in Low-Income Countries: Lessons from G-20", IMF Working Paper, No. 14/164. 
Hagemann, R.P. (2012), "Fiscal Consolidation: Part 6. What Are the Best Policy Instruments for Fiscal Consolidation?", OECD Economics Department Working Papers, No. 937, OECD Publishing, Paris.

Hagemann, R.P. (2011), "How Can Fiscal Councils Strengthen Fiscal Performance?", OECD Journal: Economic Studies, Vol. 2011/1.

Halac, M. and P. Yared (2014), "Fiscal Rules and Discretion under Persistent Shocks", Econometrica, Vol. 82, No. 5, pp. 1557-1614.

Hepp, R. and J. von Hagen (2009), "Fiscal Federalism in Germany: Stabilization and Redistribution Before and After the Unification", CEPR Discussion Paper, No. 7246.

Hers, J. and W. Suyker (2014), "Structural Budget Balance: A Love at First Sight Turned Sour", CPB Policy Brief, 2014/07

IMF (2014), "Public Expenditure Reform: Making Difficult Choices", Fiscal Monitor, Washington D.C., April.

Kastrop, C., G. Meister-Scheufelen and M. Sudhof (2010) (eds.), Die neuen Schuldenregeln im Grundgesetz, Berliner Wissenschaft Verlag, pp. 121-23, Berlin.

Klein, C., R. W. Price and A. Wörgötter (2013), "Improving the Fiscal Framework to Enhance Growth in an Era of Fiscal Consolidation in Slovakia", OECD Economics Department Working Papers, No. 1018, OECD Publishing, Paris.

Kopits, G. (2014), "Coping with fiscal risk: Analysis and practice”, OECD Journal on Budgeting, Vol. 14/1. http://dx.doi.org/10.1787/budget-14-5jxrgssdqnlt.

Kopits, G. (2011a), "Can Fiscal Discipline be Reconciled with Fiscal Sovereignty?", in Banca d'Italia (ed.), Fiscal Policy: Rules and Institutions for Sound Fiscal Policy After the Crisis, acts of the 13th Public Finance Workshop held in Perugia, 31 March - 2 Avril.

Kopits, G. (2011b), “Independent Fiscal Institutions: Developing Good Practices”, OECD Journal on Budgeting, Vol. 11/3, http://dx.doi.org/10.1787/budget-11-5kg3pdgcpn42.

Krogstrup, S. and C. Wyplosz (2010), "A Common Pool Theory of Supranational Debt Ceilings", European Economic Review 54, 269-78.

Kumar, M. S. and J. Woo (2010), "Public Debt and Growth", IMF Working Paper, No. 10/174, International Monetary Fund.

Kydland, F. and E. Prescott (1977), "Rules Rather Than Discretion: The Inconsistency of Optimal Plans", Journal of Political Economy, Vol. 85, pp. 473-91.

Larch, M. and A. Turrini (2008), "Received Wisdom and Beyond: Lessons from Fiscal Consolidation in the EU", European Economy, Economic Papers, No. 320, European Commission, Brussels.

Lojsch, D.H., M. Rodríguez-Vives and M. Slavík (2011), "The Size and Composition of Government Debt in the Euro Area", ECB Occasional Paper Series, No. 32.

Manasse, P. (2006), "Pro-cyclical Fiscal Policy: Shocks, Rules, and Institutions: A View from MARS", IMF Working Paper, No. 06/27.

Marneffe, W. (2011), Marneffe, W., B. van Aarle, W. van der Wielen and L. Vereeck (2011), "The Impact of Fiscal Rules on Public Finances in the Euro Area", CESifo DICE Report, Vol. 9, Issue 3, pp. 18-26. 
Mendoza, E., L. Tesar and J. Zhang (2014) "Saving Europe?: The Unpleasant Arithmetic of Fiscal Austerity in Integrated Economies," NBER Working Papers 20200, National Bureau of Economic Research, Inc.

Merola, R. and D. Sutherland (2012), "Fiscal Consolidation: Part 3. Long-Run Projections and Fiscal Gap Calculations", OECD Economics Department Working Papers, No. 934, OECD Publishing, Paris.

Molnar, M. (2012), « Fiscal Consolidation: Part 5. What Factors Determine the Success of Consolidation Efforts?", OECD Economics Department Working Papers, No. 936, OECD Publishing, Paris.

Nerlich, C. and W. H. Reuter (2013), "The Design of National Fiscal Frameworks and their Budgetary Impact", European Central Bank Working Paper Series, No. 1588.

Nickel, C. and A. Tudyka (2014), "Fiscal Stimulus in Times of High Debt: Reconsidering Multipliers and Twin Deficits", Journal of Money, Credit and Banking, Vol. 46(7), pp. 1313-1344.

OECD (2014), "Draft Recommendation of the OECD Council on the Principles of Budgetary Governance", OECD Publishing, Paris, www.oecd.org/gov/budgeting/OECD-Recommendation-on-Principles-for-Independent-FiscalInstitutions.pdf.

Ollivaud, P. and D. Turner (2014), "The Effect of the Global Financial Crisis on OECD Potential Output", OECD Economics Department Working Papers, No. 1166, OECD Publishing, Paris.

Panizza, U. and A. F. Presbitero (2014), "Public Debt and Economic Growth: Is there a Causal Link?", Journal of Macroeconomics, Vol. 41, pp. 21-41.

Persson, T.and G. Tabellini, (2000), "Political Economics: Explaining Economic Policy", Cambridge, MA: MIT Press.

Persson, T. and L.E. Svensson (1989), "Why a Stubborn Conservative Would Run a Deficit: Policy with Time-Inconsistent Preferences", Quarterly Journal of Economics, Vol. 104, 325-45.

Posner, P. L. and M. Sommerfeld (2013), "The Politics of Fiscal Austerity: Democracies and Hard Choices", OECD Journal on Budgeting, Vol. 13/1, http://dx.doi.org/10.1787/budget-13-5k3w6lk42/33.

Poterba, J. (1994), "State Responses to Fiscal Crises: The Effects of Budgetary Institutions and Politics", Journal of Political Economy, Vol. 102, No. 4.

Price, R. W. and T. Dang (2011), "Adjusting Fiscal Balances for Asset Price Cycles", OECD Economics Department Working Papers, No. 868, OECD Publishing, Paris.

Ramey, V. (2011), "Can Government Purchases Stimulate the Economy?", Journal of Economic Literature, Vol. 49(3), pp. 673-685

Rawdanowicz, Ł. (2012), "Choosing the Pace of Fiscal Consolidation", OECD Economics Department Working Papers, No. 992, OECD Publishing, Paris.

Reinhart, C. and K. Rogoff (2011), "From Financial Crash to Debt Crisis", American Economic Review, Vol. 101, No. 5, pp. 1676-706.

Reinhart, C.M. and K.S. Rogoff (2010), "Growth in a Time of Debt", American Economic Review, Vol. 100, No. 2, pp. 573-78. 
Reinhart, C. and K. Rogoff, (2009), This Time Is Different: Eight Centuries of Financial Folly, Princeton, New Jersey: Princeton University Press.

Röhn, O. (2010), "New Evidence on the Private Saving Offset and Ricardian Equivalence", OECD Economics Department Working Papers, No. 762, OECD Publishing, Paris.

Sorbe, S. (2012), "Portugal - Assessing the Risks around the Speed of Fiscal Consolidation in an Uncertain Environment", OECD Economics Department Working Papers, No. 984, OECD Publishing, Paris.

Strasky, J. (2015), "Public Capital Stock and the Debt-to-GDP Ratios in 22 OECD Countries", OECD Economics Department Working Papers, forthcoming.

Sutherland, D. and P. Hoeller (2012), "Debt and Macroeconomic Stability", OECD Economics Department Working Papers, No. 1003, OECD Publishing, Paris.

Sutherland, D., P. Hoeller and R. Merola (2012), "Fiscal Consolidation: Part 1. How Much is Needed and How to Reduce Debt to a Prudent Level?", OECD Economics Department Working Papers, No. 932, OECD Publishing, Paris.

Taylor, J.B. (2000), "Reassessing Discretionary Fiscal Policy", Journal of Economic Perspectives, American Economic Association, Vol. 14(3), pp. 21-36.

Tornell, A. and P. Lane (1999), "The Voracity Effect", American Economic Review, Vol. 89, pp. 22-46.

Turner, D. (2006), "Should Measures of Fiscal Stance be Adjusted for Terms of Trade Effects?", OECD Economics Department Working Papers, No. 519, OECD Publishing, Paris.

Turner, D. and F. Spinelli (2013), "The Effect of Government Debt, External Debt and their Interaction on OECD Interest Rates", OECD Economics Department Working Papers, No. 1103, OECD Publishing, Paris.

Von Hagen, J. and R.R. Strauch (2001), "Fiscal Consolidations: Quality, Economic Conditions, and Success", Public Choice, Vol. 109(3-4), pp. 327-346.

Von Hagen, J. and I. Harden (1994), "National Budget Processes and Fiscal Performance", European Economy. Reports and Studies, Vol. 3, pp. 315-418.

Wyplosz, C. (2013), "Fiscal Rules, Theoretical Issues and Historical Experiences", in A. Alesina and F. Giavazzi (eds.), Fiscal Policy after the Financial Crisis, NBER, The University of Chicago Press, Chicago. 


\section{APPENDIX}

Table A.1. Fiscal reaction function

\begin{tabular}{|c|c|c|c|c|c|c|c|}
\hline & $(1)$ & $(2)$ & (3) & $(4)$ & (5) & $(6)$ & $(7)$ \\
\hline Dependent variable & $\begin{array}{l}\text { Primary } \\
\text { balance }\end{array}$ & $\begin{array}{l}\text { Primary } \\
\text { balance }\end{array}$ & $\begin{array}{l}\text { Primary } \\
\text { balance }\end{array}$ & $\begin{array}{l}\text { Primary } \\
\text { balance }\end{array}$ & $\begin{array}{l}\text { Primary } \\
\text { balance }\end{array}$ & $\begin{array}{l}\text { Primary } \\
\text { balance }\end{array}$ & $\begin{array}{l}\text { Primary } \\
\text { balance }\end{array}$ \\
\hline \multirow[t]{2}{*}{ Gap } & $0.42^{\star \star \star}$ & $0.38^{\star \star \star}$ & $0.43^{\star \star \star}$ & $0.49^{\star \star \star}$ & $0.42^{\star \star \star}$ & $0.43^{\star \star \star}$ & $0.39 * * \star$ \\
\hline & $(0.029)$ & $(0.043)$ & $(0.029)$ & $(0.034)$ & $(0.029)$ & $(0.029)$ & $(0.031)$ \\
\hline \multirow[t]{2}{*}{ Lag (debt) below d1 } & $0.017^{*}$ & -0.008 & 0.025 & $0.059 * *$ & $0.018^{*}$ & 0.011 & $0.018^{*}$ \\
\hline & (0.009) & $(0.007)$ & $(0.016)$ & $(0.024)$ & $(0.009)$ & $(0.010)$ & $(0.010)$ \\
\hline Lag (debt) between & $0.064^{\star \star}$ & $-0.074^{\star \star}$ & $2.60 * \star$ & 0.003 & $0.065^{\star \star}$ & $0.046^{*}$ & $0.067^{\star \star}$ \\
\hline $\mathrm{d} 1$ and $\mathrm{d} 2$ & $(0.027)$ & $(0.037)$ & (1.09) & $(0.011)$ & $(0.027)$ & $(0.024)$ & $(0.028)$ \\
\hline \multirow[t]{2}{*}{ Lag (debt) above d2 } & $-0.11 * \star \star$ & $-0.14^{\star \star}$ & $-0.83^{*}$ & $-0.11^{\star \star \star}$ & $-0.11 * \star \star$ & $-0.098^{\star *}$ & $-0.11 * \star \star$ \\
\hline & $(0.041)$ & $(0.064)$ & $(0.43)$ & $(0.040)$ & $(0.040)$ & $(0.040)$ & $(0.041)$ \\
\hline \multirow{2}{*}{ One-off } & $-1.00^{\star \star \star}$ & $-1.02^{\star \star *}$ & $-1.01^{\star \star \star}$ & $-1.03^{\star \star *}$ & $-1.04^{\star \star \star}$ & $-0.97^{\star \star *}$ & $-1.01^{\star \star \star}$ \\
\hline & $(0.036)$ & $(0.046)$ & $(0.038)$ & $(0.041)$ & $(0.039)$ & $(0.038)$ & $(0.037)$ \\
\hline Openness x & $0.034^{\star * *}$ & $0.011^{\star \star \star}$ & $0.029 * \star \star$ & $0.035^{\star \star \star}$ & $0.033^{* * *}$ & $0.033^{* \star \star}$ & $0.034^{\star * \star}$ \\
\hline terms of trade & $(0.008)$ & $(0.004)$ & $(0.008)$ & $(0.009)$ & $(0.008)$ & $(0.0083)$ & $(0.009)$ \\
\hline \multirow[t]{2}{*}{ Lag (assets (a)) } & & & 0.022 & & & & \\
\hline & & & $(0.018)$ & & & & \\
\hline \multirow[t]{2}{*}{ Lag (debt below d1 x a) } & & & -0.017 & & & & \\
\hline & & & $(0.026)$ & & & & \\
\hline Lag (debt between & & & $-3.01 * \star$ & & & & \\
\hline $\mathrm{d} 1$ and $\mathrm{d} 2 \times \mathrm{a})$ & & & $(1.39)$ & & & & \\
\hline & & & $0.86^{*}$ & & & & \\
\hline & & & $(0.52)$ & & & & \\
\hline \multirow[t]{2}{*}{ Lag (real interest rate (r)) } & & & & -0.027 & & & \\
\hline & & & & $(0.090)$ & & & \\
\hline \multirow[t]{2}{*}{ Lag (debt below d1 x r) } & & & & 0.24 & & & \\
\hline & & & & $(0.25)$ & & & \\
\hline Lag (debt between & & & & $0.32^{\star \star}$ & & & \\
\hline $\mathrm{d} 1$ and $\mathrm{d} 2 \times \mathrm{r}$ ) & & & & $(0.14)$ & & & \\
\hline \multirow[t]{2}{*}{ Lag (debt above d2 x r) } & & & & 0.91 & & & \\
\hline & & & & $(0.67)$ & & & \\
\hline \multirow[t]{2}{*}{ Lag (One-off) } & & & & & $-0.12^{\star \star \star}$ & & \\
\hline & & & & & $(0.039)$ & & \\
\hline \multirow[t]{2}{*}{ IMF programme } & & 0.011 & & & & $0.017^{\star \star}$ & \\
\hline & & $(0.007)$ & & & & $(0.007)$ & \\
\hline \multirow[t]{2}{*}{ Inflation } & & $0.14^{\star \star \star}$ & & & & & $0.097^{* * *}$ \\
\hline & & $(0.055)$ & & & & & $(0.035)$ \\
\hline \multirow[t]{2}{*}{ Old age dependency ratio } & & $0.001^{\star *}$ & & & & & \\
\hline & & $(5 e-04)$ & & & & & \\
\hline \multirow[t]{2}{*}{ Lag (debt x r) } & & $0.26^{\star \star \star}$ & & & & & \\
\hline & & $(0.051)$ & & & & & \\
\hline \multirow[t]{2}{*}{ Lag (Government size) } & & $-0.099 \star \star \star *$ & & & & & \\
\hline & & $(0.028)$ & & & & & \\
\hline \multirow[t]{2}{*}{ Euro area } & & -0.005 & & & & & \\
\hline & & $(0.004)$ & & & & & \\
\hline \multirow[t]{2}{*}{ House price change } & & $0.073^{\star \star \star}$ & & & & & \\
\hline & & $(0.016)$ & & & & & \\
\hline Stock price change & & $0.012^{\star \star \star}$ & & & & & \\
\hline & & $(0.003)$ & & & & & \\
\hline d1 & $123 \%$ & $137 \%$ & $156 \%$ & $51 \%$ & $123 \%$ & $117 \%$ & $123 \%$ \\
\hline $\mathrm{d} 2$ & $168 \%$ & $180 \%$ & $164 \%$ & $157 \%$ & $168 \%$ & $168 \%$ & $168 \%$ \\
\hline Sample & $1985-2013$ & $1985-2013$ & $1985-2013$ & $1985-2013$ & $1985-2013$ & $1985-2013$ & $1985-2013$ \\
\hline Country fixed effects & yes & no & yes & Yes & yes & yes & yes \\
\hline $\mathrm{N}$ & 709 & 512 & 699 & 604 & 706 & 709 & 658 \\
\hline Rho & 0.75 & 0.71 & 0.73 & 0.67 & 0.75 & 0.75 & 0.76 \\
\hline $\mathrm{R}^{2}$ & 0.633 & 0.653 & 0.635 & 0.661 & 0.637 & 0.636 & 0.637 \\
\hline
\end{tabular}

Note: Panel regression with AR(1) Prais-Winsten correction and panel heteroskedasticity-robust standard errors. Standard errors are in parenthesis. Norway is excluded from the third specification because it is not comparable to the other OECD countries: its high net financial worth mainly reflects past oil-related government receipts. 